\title{
منهم الشيخ
}

\section{بد الرهن بن ناهر السعي وأثره في أصول الثت ني}

\author{
إعداد الدكتور \\ نواف بن رحيل الشراري \\ وكيل كلية الثريعة و الأنظمة \\ بجامعة تبوك بالمملكة العربية السعودية
}


$-07.7=$ 


\section{منهج الشيخ \\ عبد الرحمن بن ناصر السعدي \\ وأثره في أصول الفقه بن لاصن التهن}

نواف بن رحيل الثراري

قسم الثريعة ، كلية الثريعة والأنظمة ، جامعة تبوك ، المملكة العربية السعودية .

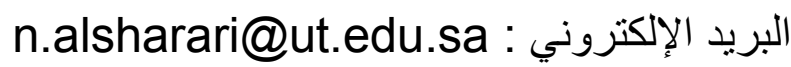

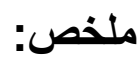

جاء هذا البحث ليسلط الضوء على علم من أعلام أصول الفقه المعاصر هو: الثيخ

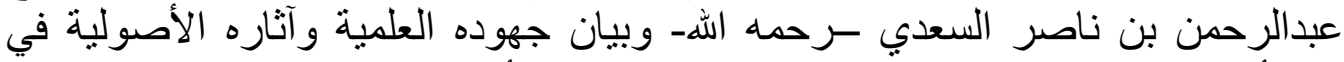

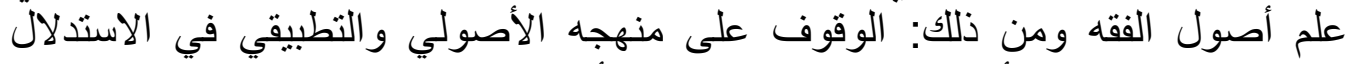

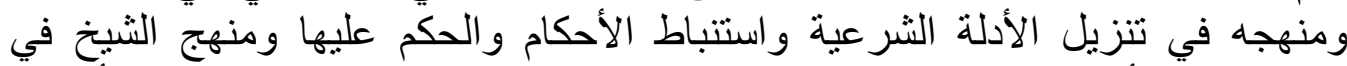

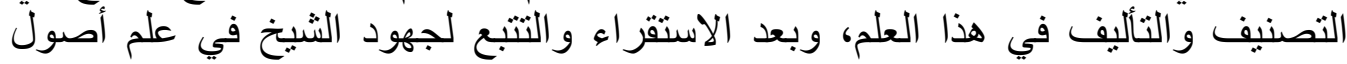

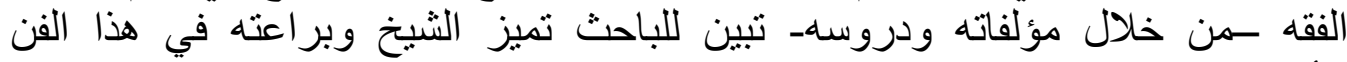

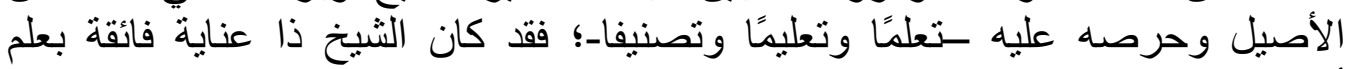
أصول الفقه ومعرفتة تامة به . الاصنه

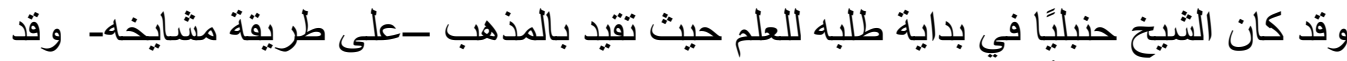

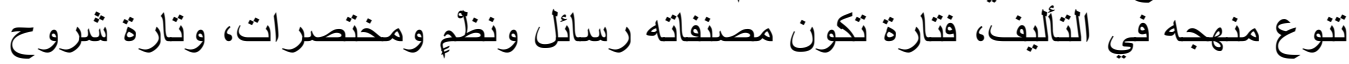

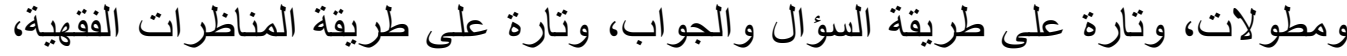

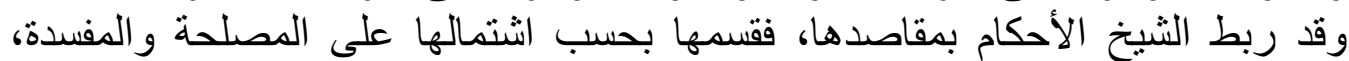

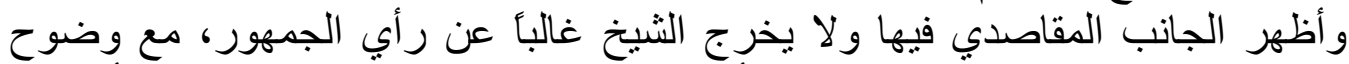

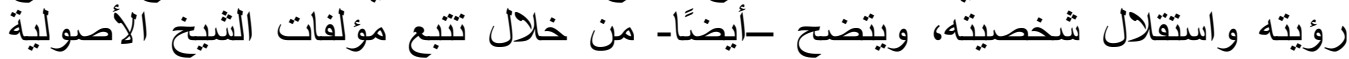

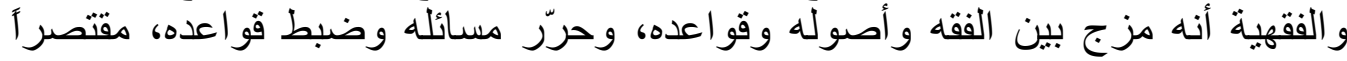

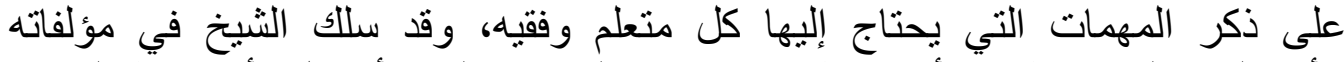

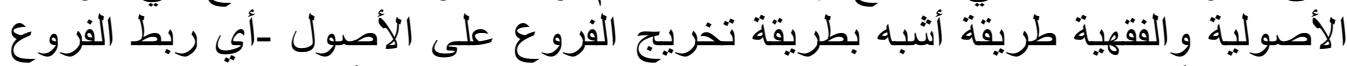

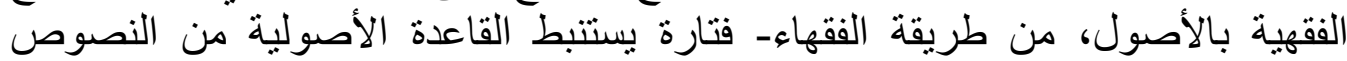

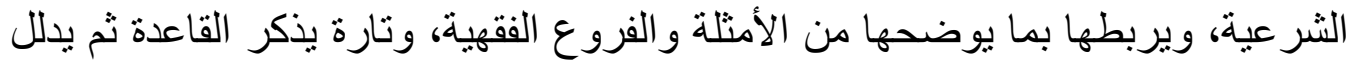

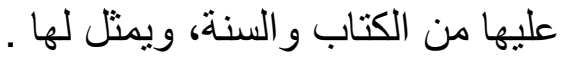

الكلمات الافتتاحية: عبدالرحمن السعدي ، السعدي ، الفقه الحنبلي ، علماء نجد ، أصول

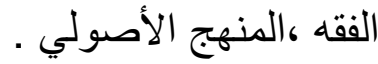




\section{The Sheikh's approach}

Abdul Rahman bin Nasser Al-Saadi

\section{And its effect on the principles of jurisprudence}

Nawwaf bin Rahil Sharari

Department of Sharia, College of Sharia and Regulations, University of Tabuk, Saudi Arabia.

E-mail: n.alsharari@ut.edu.sa

\section{Abstract:}

This research came to shed light on one of the distinguished scholars of the fundamentals of contemporary jurisprudence, namely: Sheikh Abdul Rahman bin Nasser Al Saadi - may God have mercy on him - and a statement of his scientific efforts and his fundamentalist effects in the science of Usul al-Figh, including: Standing on his fundamentalist and applied approach in inference and his approach to downloading legal evidence and deriving rulings and judgment On it and the Sheikh's approach to classification and authorship in this science, and after extrapolating and tracing the Sheikh's efforts in the science of fiqh - through his writings and lessons - the researcher found out to the researcher the Sheikh's distinction and mastery of this original art and his keenness on it - to learn, teach and classify - The sheikh was keenly interested in the science of usul al-figh and was fully aware of it.

The Sheikh Hanbali was at the beginning of his request for knowledge, as he adhered to the doctrine - according to the way of his sheikhs - and his method of authorship varied, sometimes his works were letters, systems and abbreviations, sometimes explanations and lengths, sometimes in the manner of question and answer, and sometimes by the method of jurisprudential debates, and the sheikh linked rulings with their objectives So, he divided it according to its inclusion of interest and corruption, and he showed the intended side in it, and the sheikh often does not deviate from 
the opinion of the public, with the clarity of his vision and the independence of his personality, and it becomes clear - also through the tracing of the Sheikh's fundamentalist and jurisprudential writings that he mixed the jurisprudence with its principles and rules, and liberated his issues and set its rules, being limited To mention the tasks that every learner and jurist need, and the sheikh has followed in his fundamentalist and jurisprudential writings a method similar to the method of graduating the branches on the origins - that is, linking the jurisprudential branches with the principles, from the way of the jurists - sometimes he derives the fundamentalist rule from the legal texts, and links it to what he clarifies from the examples and the jurisprudential branches Sometimes he mentions the rule, then demonstrates it from the Qur'an and Sunnah, and represents it.

Key words : Abd al-Rahman al-Saadi, al-Saadi, Hanbali jurisprudence, Najd scholars, Usul al-Fiqh, the fundamentalist .approach 


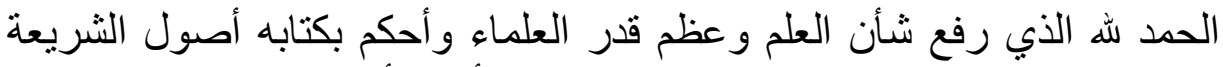

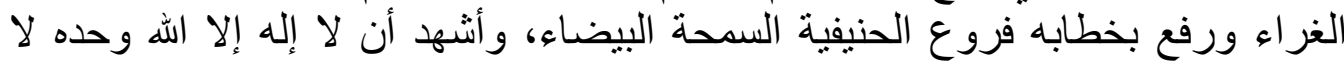

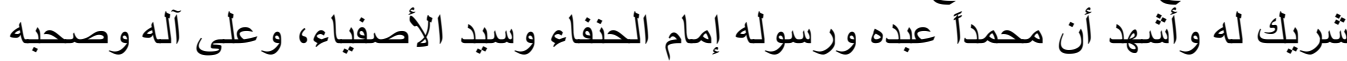

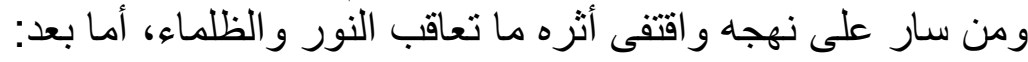

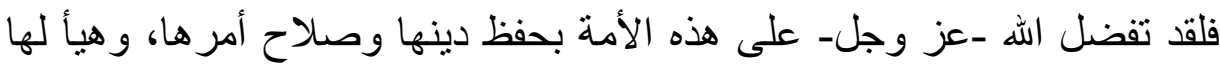

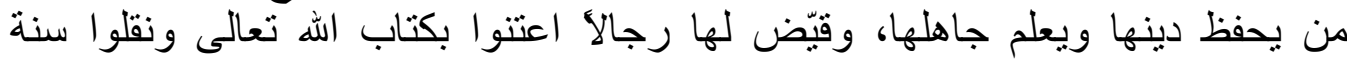

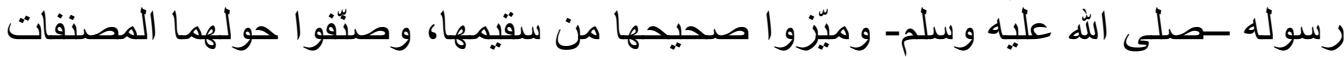

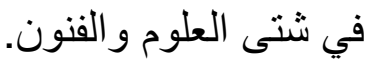

ومن هؤلاء الأئمة الأعلام الثيخ عبد الرحمن بن ناصر السعدي ــرحمه اللهـ

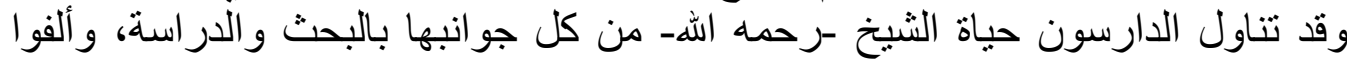

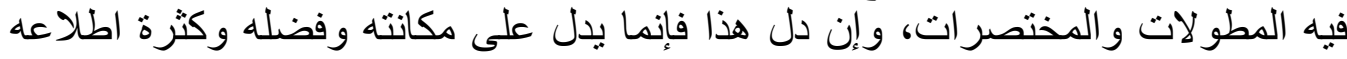

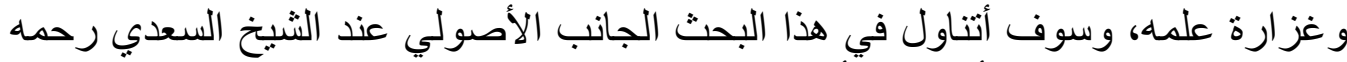

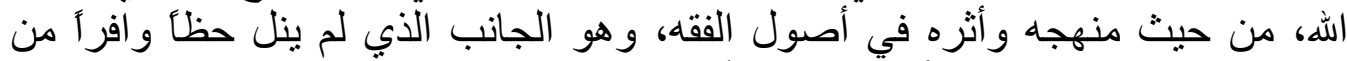

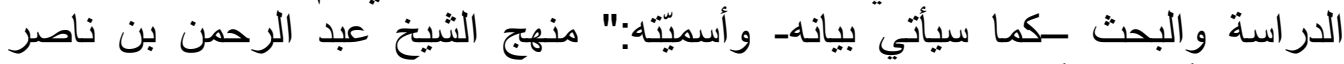
السعدي وأثزه في أصول الفقه" . الصني

لعل هذا العمل يكون نواة لأعمال مستقبلية موسعة، يكون نطاق البحث فيها أوسع كالرسائل و الكتب العلمية. و الله تعالى أسأله التوفيق و السداد، إنه ولي ذللك و القادر عليه أهمية الاراسة وسبب اختيار ها: تبرز أهمية الدراسة نظرًا لمكانة الثيخ السعدي العلمية ـرحمه اللهـ ولهذهاه

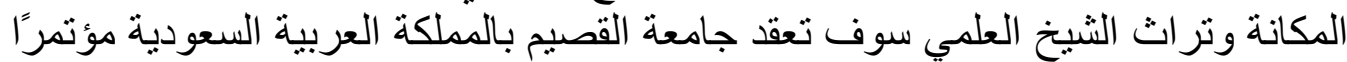

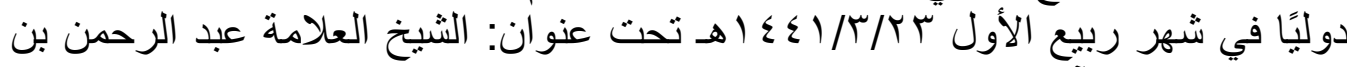

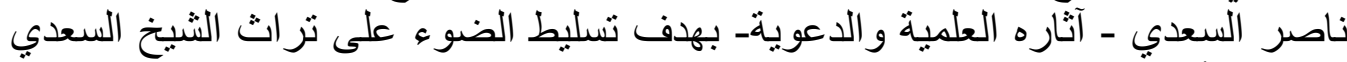

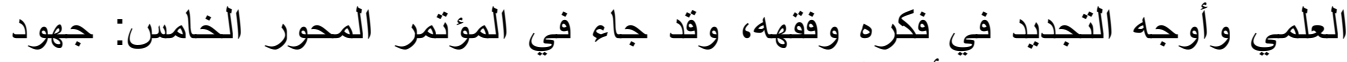
الثيخ السعدي ومنهجه في أصول النجديد في فلفه .

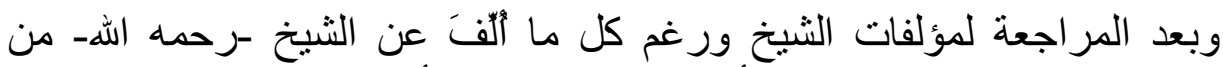

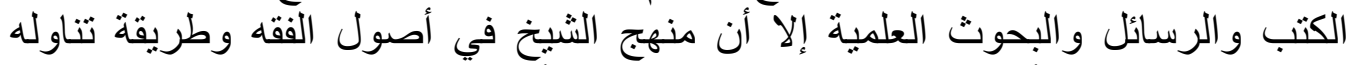

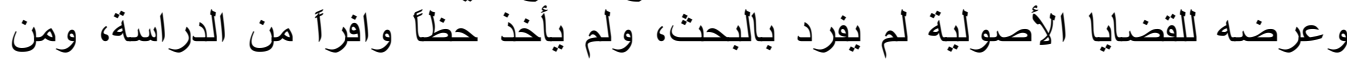

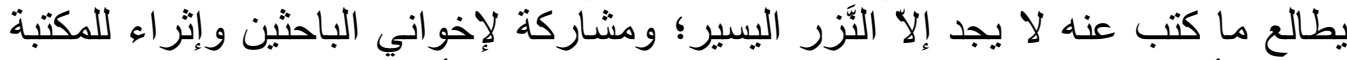

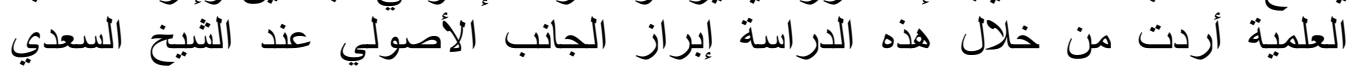

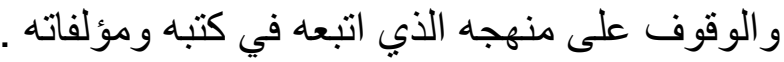




\section{الاراسات السابقة:}

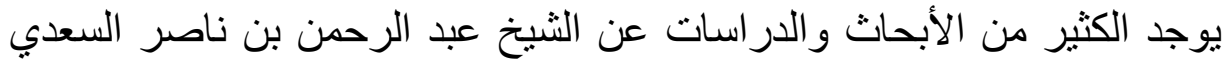

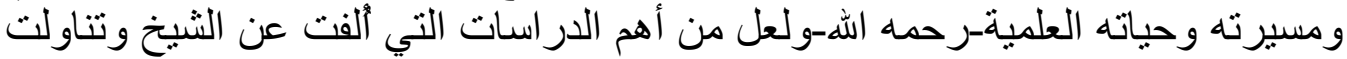

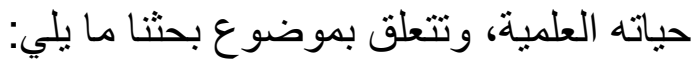

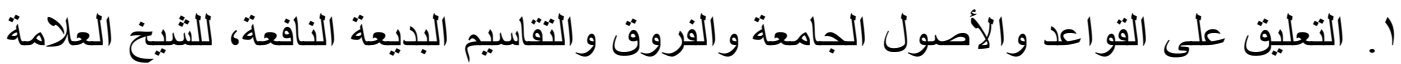

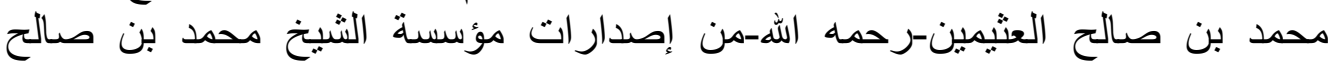
العثيمين الخيرية. r. "أثر القواعد الأصولية في اختيار ات الثيخ عبد الرحمن السعدي الفقهية، للمسائل النازلة

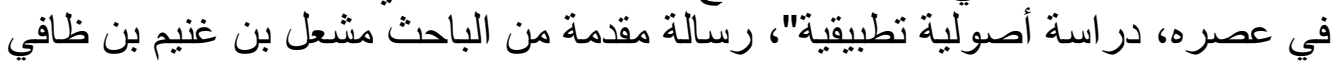

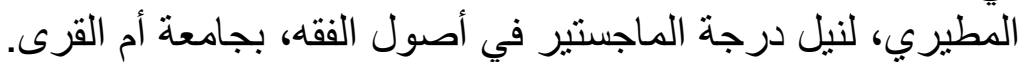

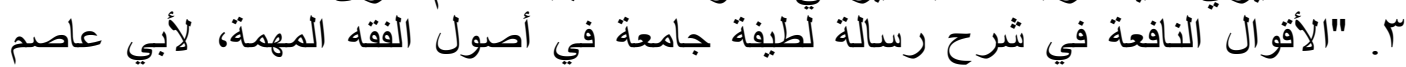

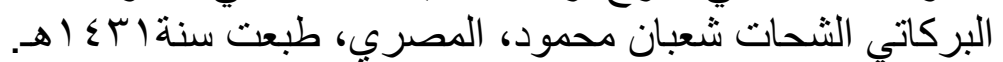

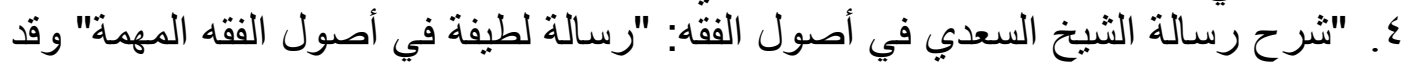

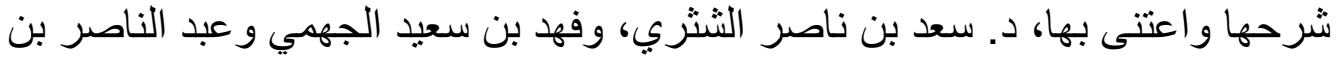
عبد القادر البشبيشي.

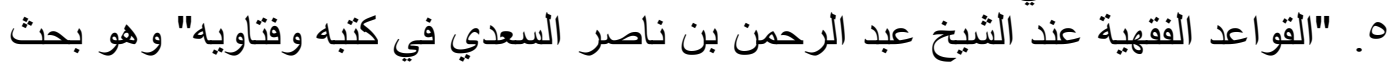

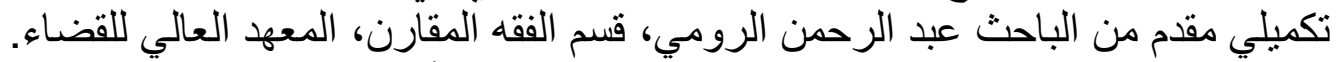

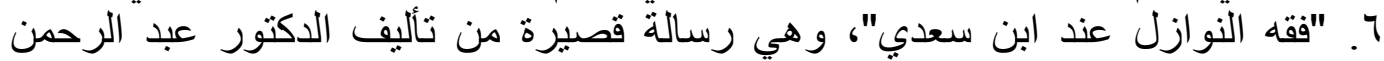

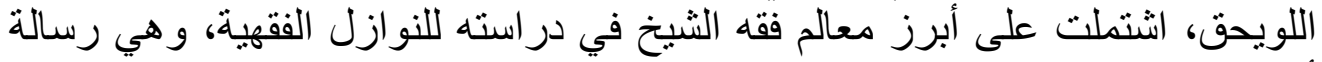

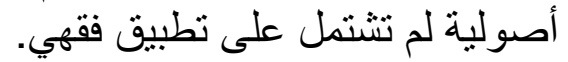
V. "فقه الثيخ السعدي"، بحث للادكتور عبد الله أحمد الطيار، و الدكتور سليمان بن حمود أبا

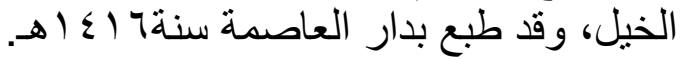

\section{مشكلة الاراسة:}

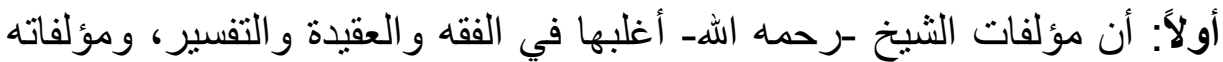

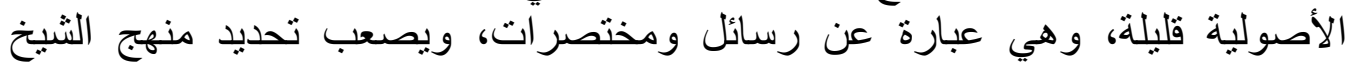
بوضوح من خلالها.

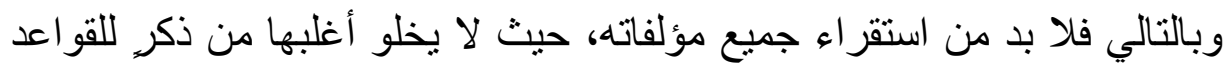

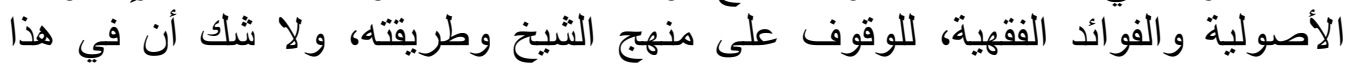
صعوبة كبيرة.

ثانياً: هناك أسئلة كثيرة يمكن إثارتها، ويمكن لهذه الدر اسة أن تجيب عليها. من هذه الأسئلة: هل اتبع الثيخ السعدي ـرحمه الله-طريقة الجمهور في تأليفاته الأصولية، أم لا؟ و هل هو محسوب على علماء الحنابلة في الأصول كما في الفروع ؟ . 


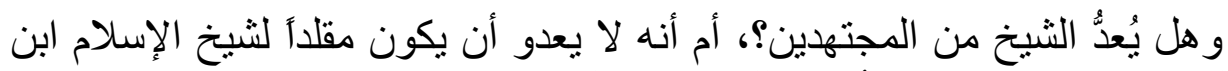

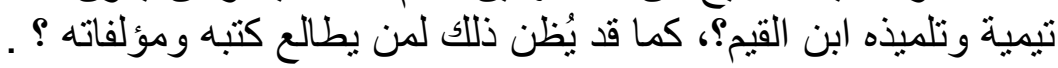
وسأحاول بإذن الله تعالى في هذا البحث أن أجيب عن هذه الأسئلة، والله تعالى ولى لئل

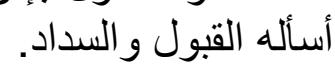

\section{منهج الاراسة:}

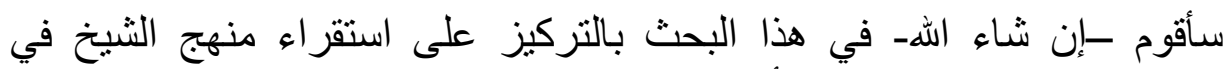

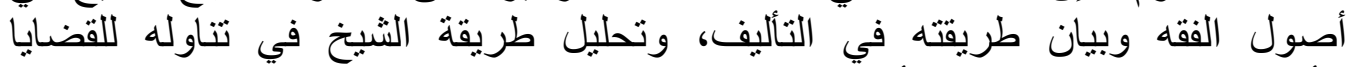

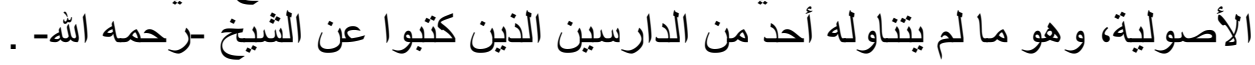
خطة الدراسة: وهو مالم

تشتمل هذه الدراسة على مقدمة وتمهيد ومبحثين وخاتمة تضمنت أهم

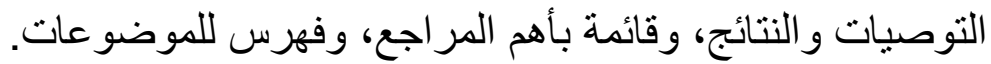

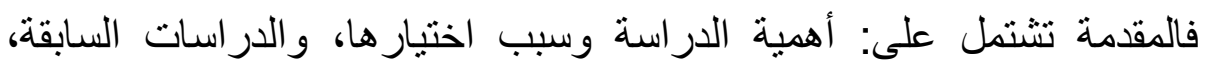
ومشكلة الدر اسة ومنهجها وخمل وخطتها. التمهيد فيه: نبذة مختصرة عن الثيخ السعدي. المبحث الأول: جهود السعدي في التأليف في أصول الفقه. المبحث الثاني: طريقة السعدي ومنهجه في مؤلفاته الأصولية. المطلب الأول: تعريف أصول الفقه. المطلب الثاني: الأدلة الثرعية. المطلب الثالث: الأحكام الثر عية. المطلب الر ابع: دلالات الألفاظ.

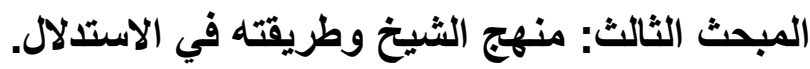

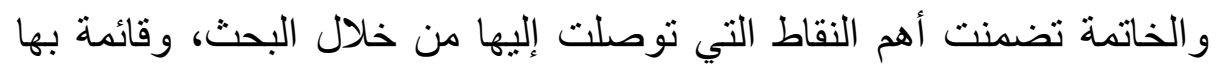

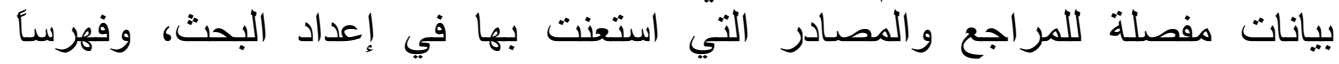
للموضو عات. 


\section{تمهيد}

\section{نبذة هختصرة عن الشيخ السعدي}

اسمه ونسبـ:

هو: العلامة الثيخ عبد الرحمن بن ناصر بن عبد الله بن ناصر بن حمد آل

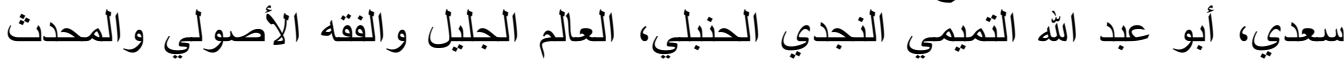

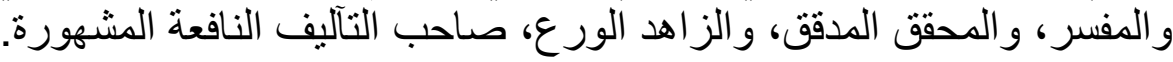

\section{مولده ونشأته:}

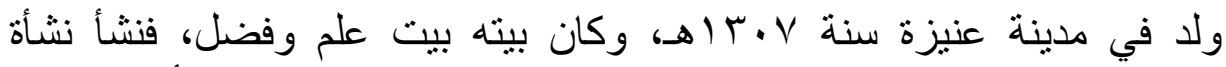

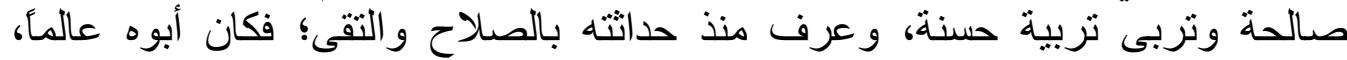

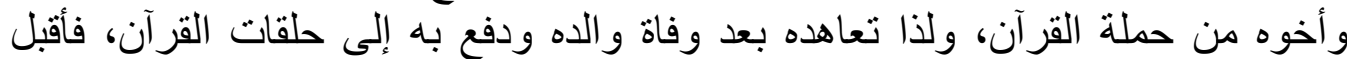

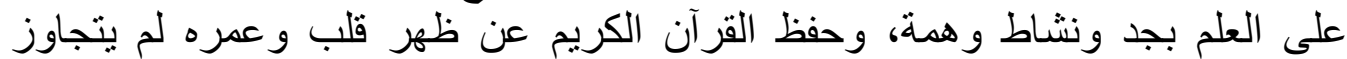
الثانية عشرة، وانقطع للعلم وجعل كل أوقاته مشغولة في تحصيلة فيله، حتى أدرك في في صباه ما لا يدركه غيره في زمن طو للفيل.

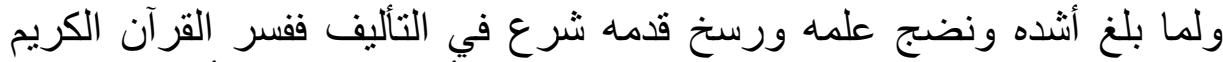

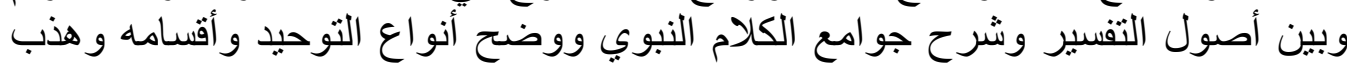

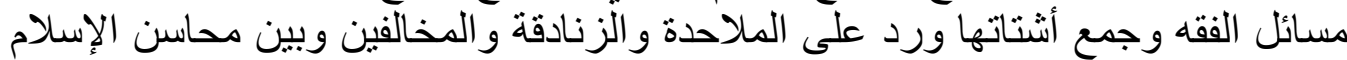
كل ذللك في كتب ورسائل طبعت ووز عت ونت ونفع الله بها.

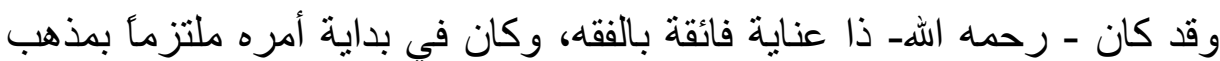

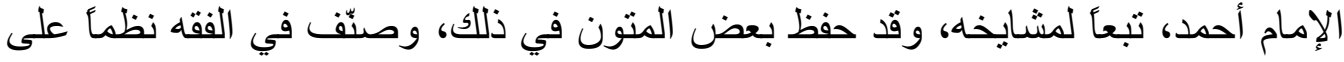

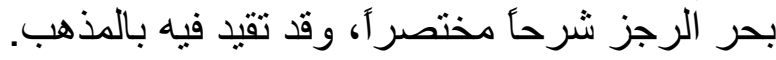

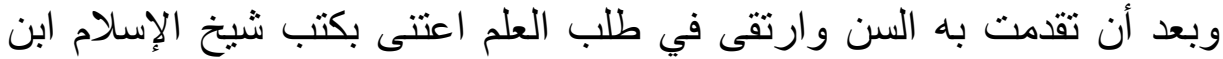

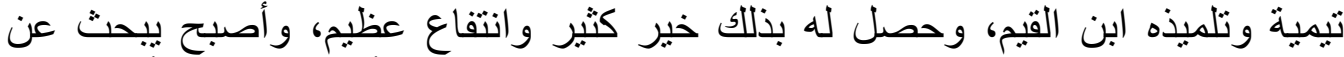

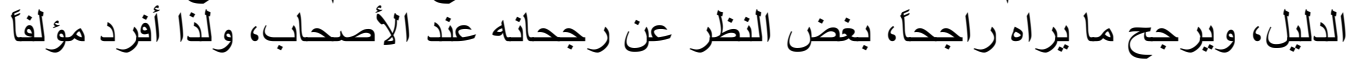

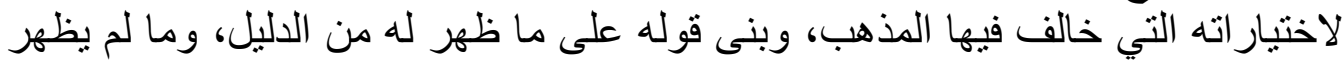

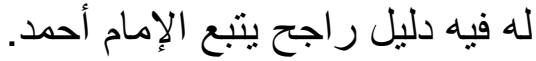

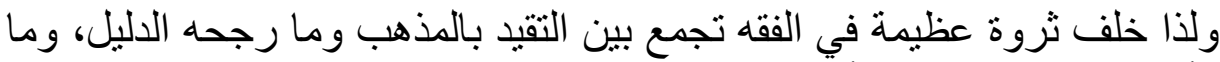

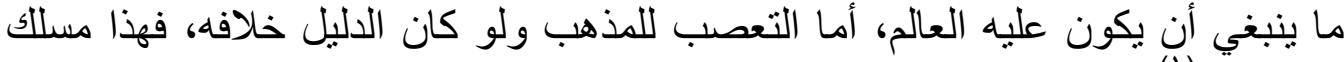

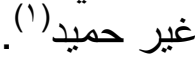

اـ انظر: صفحات من حياة علامـة القصيم، عبد الرحمن بن ناصر السعدي، تأليف: عبد الله الطبار

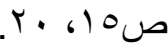


وقد أنتى عليه كثير من العلماء، فقال عنه سماحة الثيخ عبد العزيز بن باز

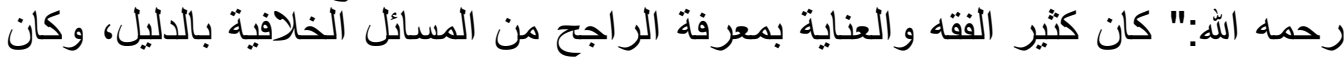

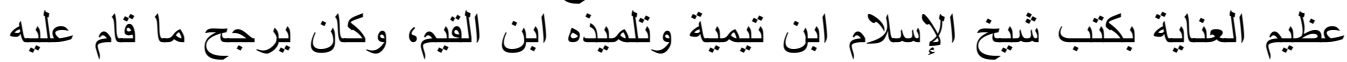

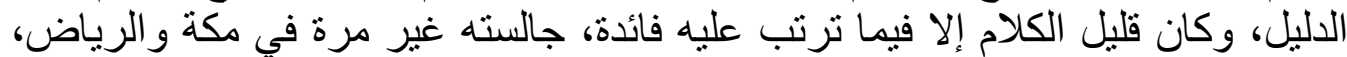

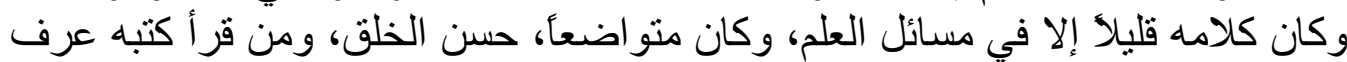
فضله و علمه، و عنايته بالدليل، فرحمه الله رحمة و واسعة".

\section{مرضه وفاته:}

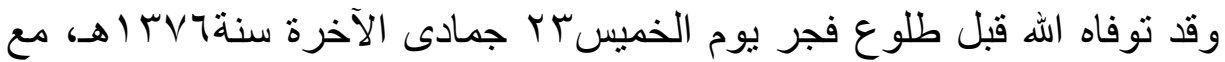

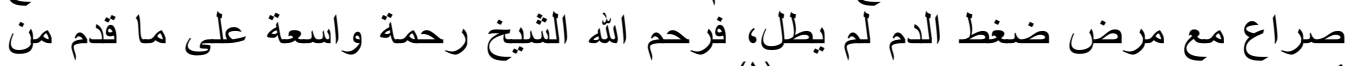
أعمال جليلة لخدمة الإسلام و المسلمين (').

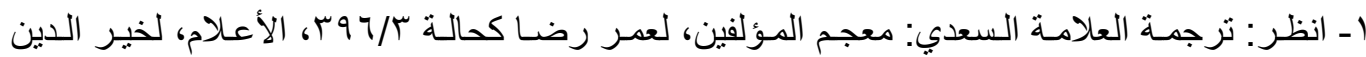

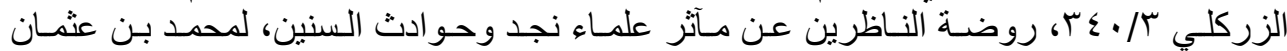

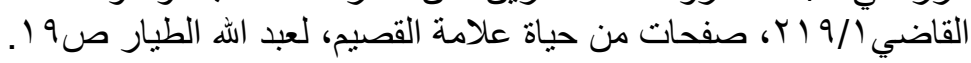




\section{المبمث الأول}

\section{جهود الشيخ السعدي في التأليف في أصول الفقه وقواعده}

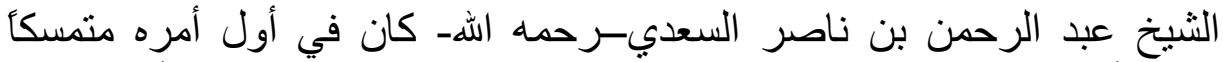

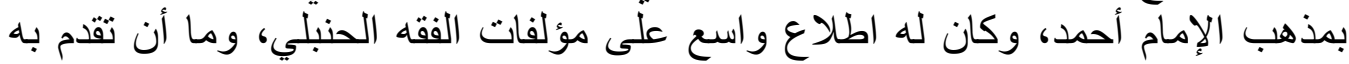

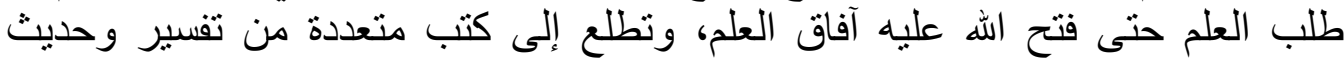

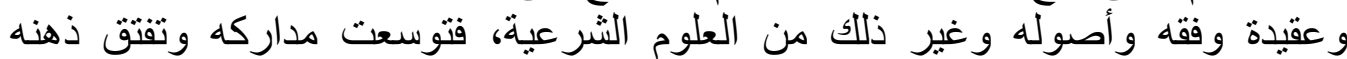
وتنو عت علومه.

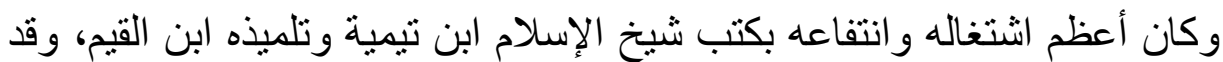

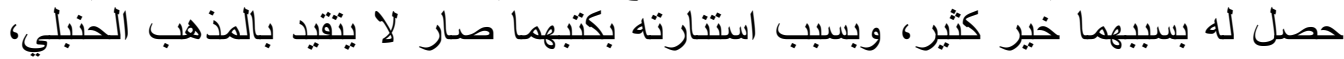

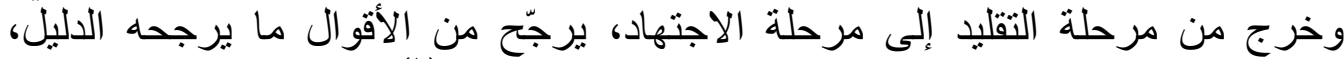
ويصدقه التعليل، ويستقي الحكم من منبعه، ويسنده إلى أصلهاه (1)

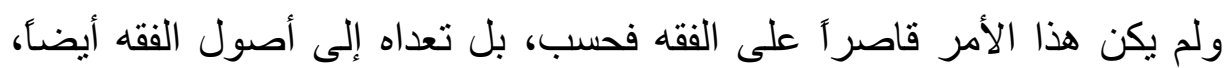

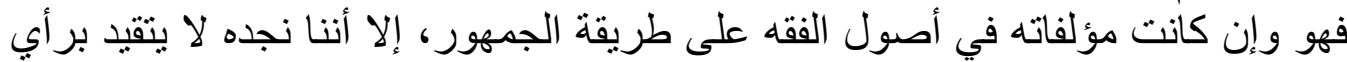
الجمهور في مواطن كثيرة، بل يرجّح ما ير اهول اهله راجحاً إذا قوي دليله.

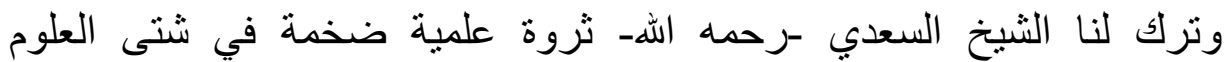

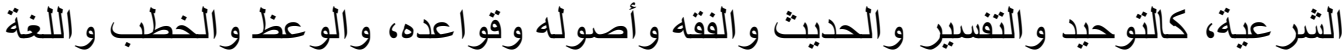

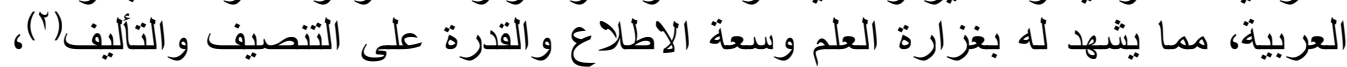
و اقتصر -في هذا المبحث- علي ذكر أهم مؤلفاته في أصول الصول الفقه وقو اعده.

1- رسالة لطيفة في أصول الفقه المهمة .

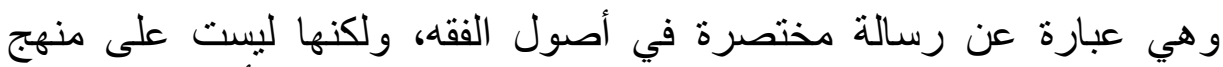

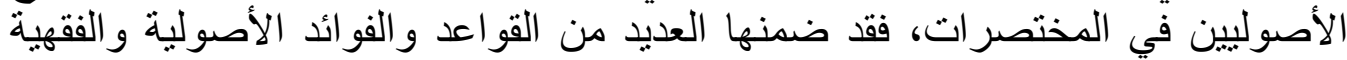

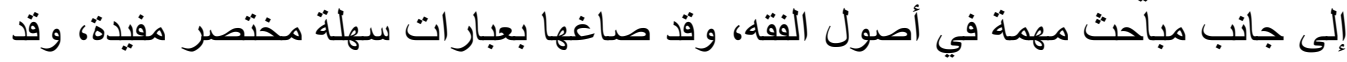

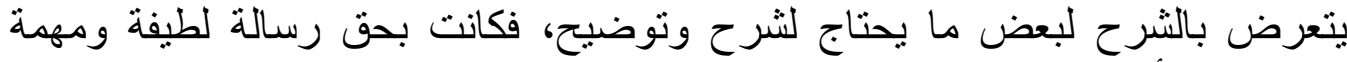
وجامعة في أصول الفقه.

قال في مقدمتها:" فهذه رسالة لطيفة في أصول الفئه الفقه، سهلة الألفاظ، واضحة

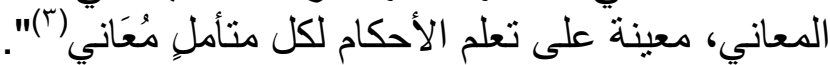

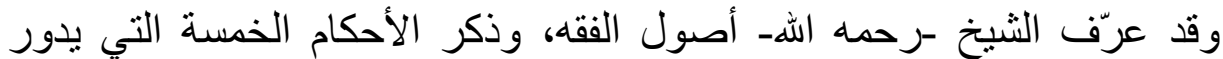

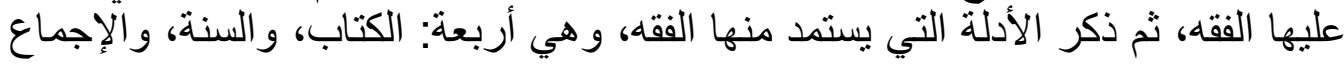

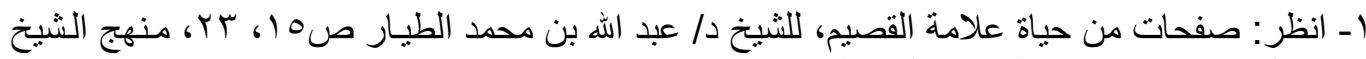

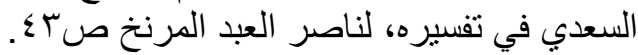

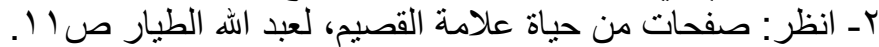

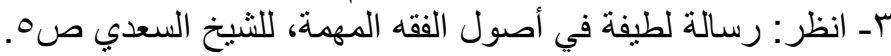


و القياس، وعرّف الكتاب والسنة، ثم ذكر مباحث دلالات الألفاظ: فذكر النص والظاهر

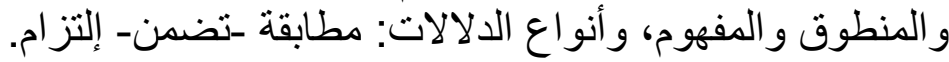

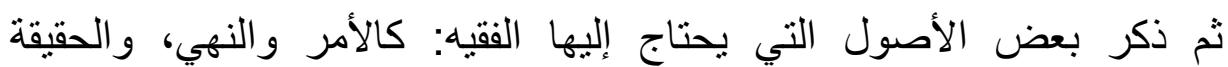

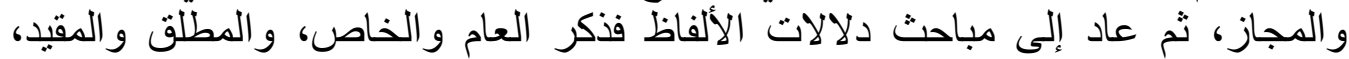

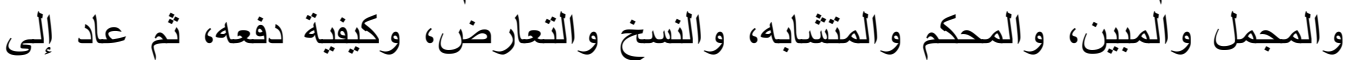

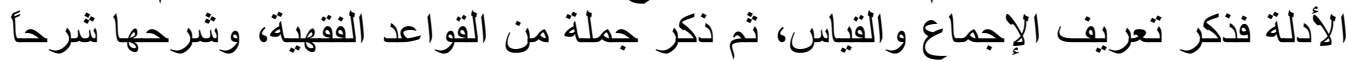

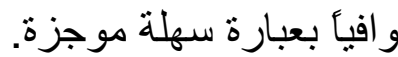

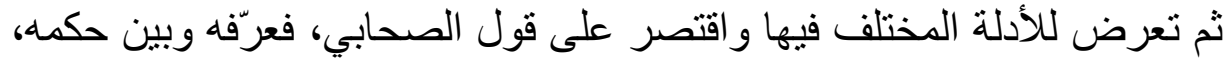

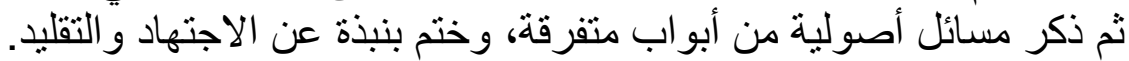
شروح هذه الرسالة:

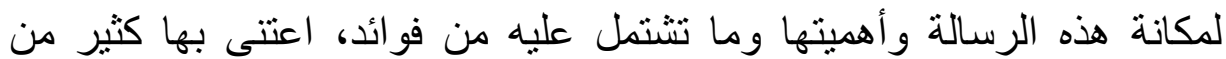

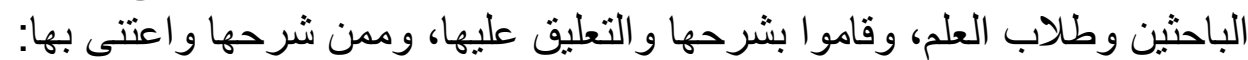
1. الدكتور سعد بن ناصر الثشري، وفهد بن سعيد الجهضمي، و عبد الناصر بن بن بهن عبد القادر البشبيشي. r. الثيخ نادر التعمري، في كتاب سماه:" التعليقات المنيفة على الته الرسالة

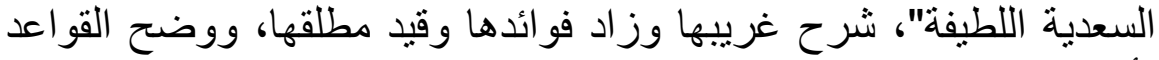
بأمثلتها. r. الثحات شعبان محمود، البركاتي المصري، في كتاب سمّاه:" الأقو ال النافعة

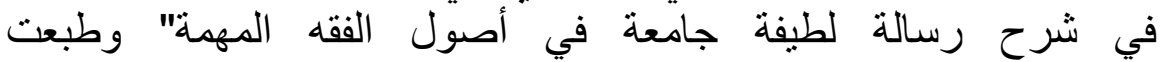

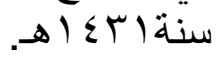

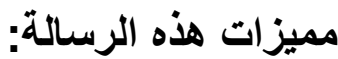

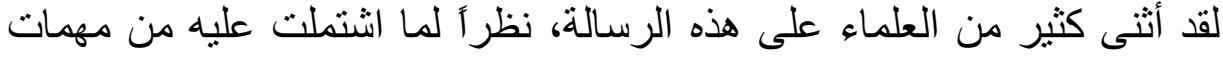

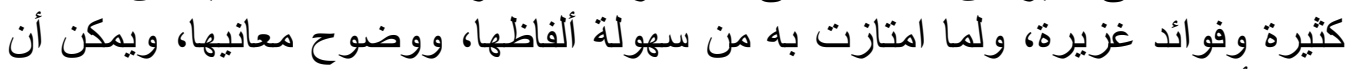

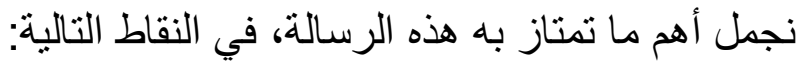

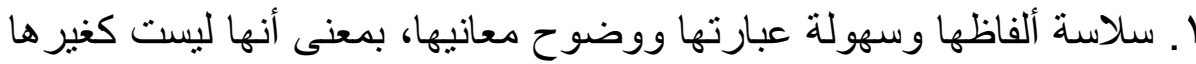
من المنون التي لا تفهم إلا إذا شرحت. r. حسن تسلسل الرسالة في تناول الموضو عات، فما من مبحث من المباحث إلا لإن وهو ينبني على ما سبقه. r. أنها صيغت في صورة قواعد كلية أصولية، وبالإضافة إلى عدد من لإنها الضوابطو القو اعد الفقهية التي لا غنى للفقيه عنها. 


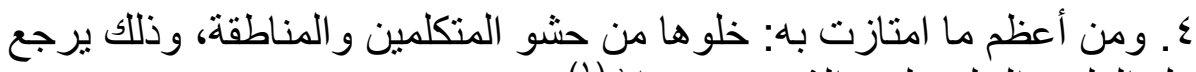

إلى التأصيل العلمي السلفي لدى الثيخ رحمه الله (').

\section{r - مختصر في أصول الفقه.}

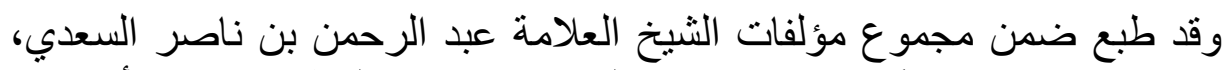

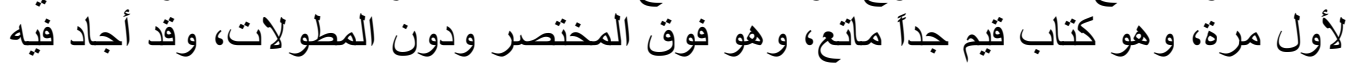
الثيخ السعدي و أبدع.

قال في أوله:" فهذا مختصر في علم أصول الفقه قريب المنال، غريب المنوال، كامل لمن اعتمده إن شاء الله بيلوغ الآمال، وارتفاع فئه ذأهروة الكمال".

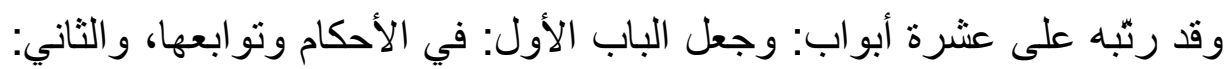

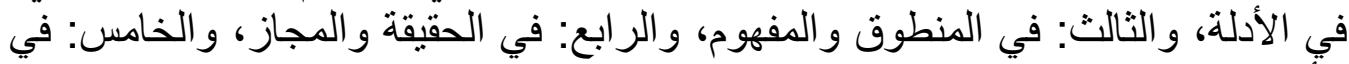

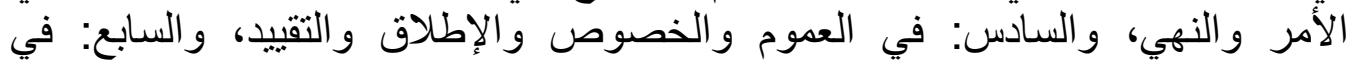
المجمل و المبيّن والظاهر و المؤول، والثين والثامن: في النسخ، والتاسع: في الاجتهاد و التقليد، و العاشر: في الترجيح.

ثم ذكر خاتمة في الحدود، ذكر فيها مجموعة من المصطلحات التي يحتاج إليها

$$
\text { طالب علم أصول الفقه. }
$$

\section{r- صفوة أصول الفقه المنتخبة من مختصر التحرير.}

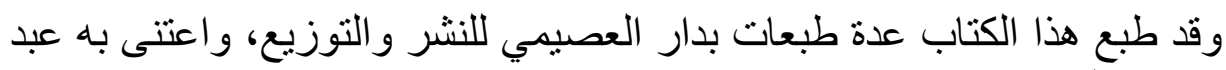

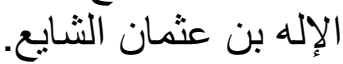

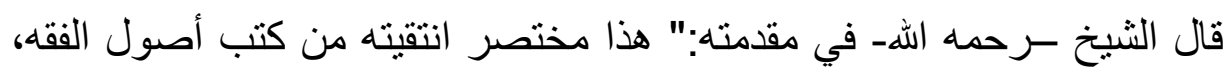

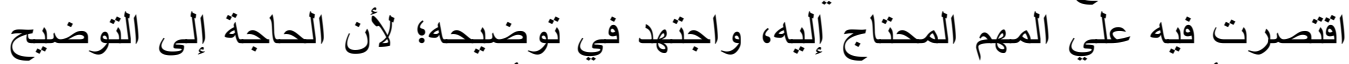

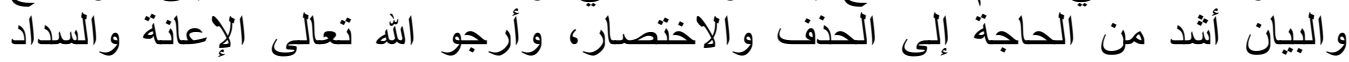
وسلوك أقرب طريق يوصل إلى الى الهدي و الرشاد بمنه وكرمده(؟)".

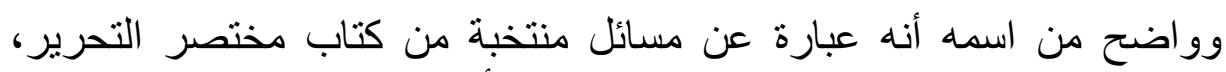

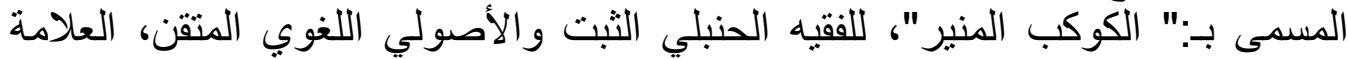

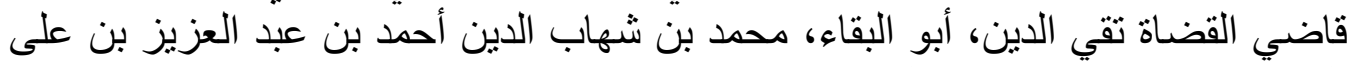

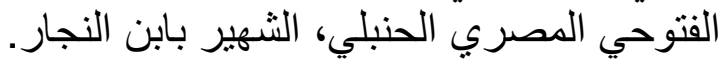

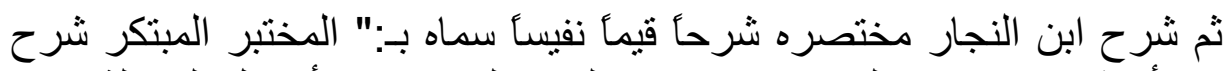

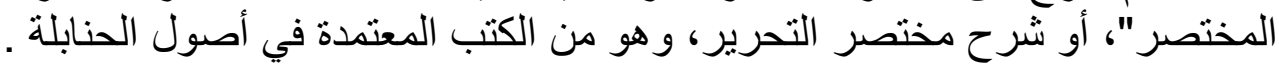

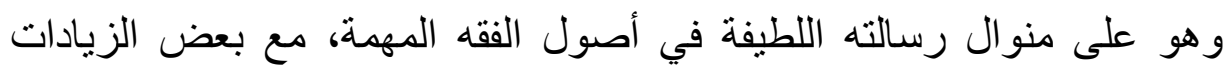
و الإفادات المهمة، وقد قال في أوله:" أصول الفقه هي: الأدلة الموصلة إليه، وأصلها 
الكتاب و السنة و الإجماع و القياس، و الأحكام الثر عية خمسة الو اجب و الحر ام و المسنون

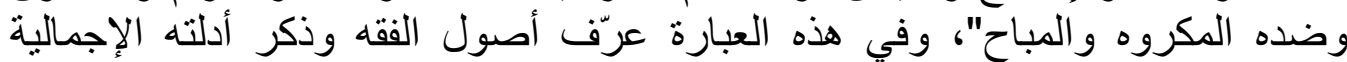

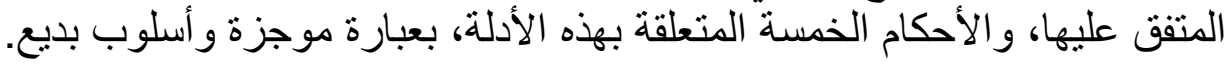

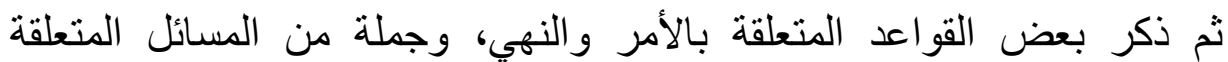
بدلالات الألفاظ، وأهم القواعد الفقهية التي يحتاج الفقيه إليها، على غرالى غرار ما فا فعل في رسالته الأصوليّة السابق ذكر ها.

\section{عـ القواعد والأصول الجامعة، والفروق والتقاسيم البديعة النافعة.}

وقد طبع ضمن مجموع مؤلفات الثيخ السعدي ـرحمه الله- بدار الميمان للنشر

$$
\text { و التوزيع بالرياض، المجلد الر ابع. }
$$

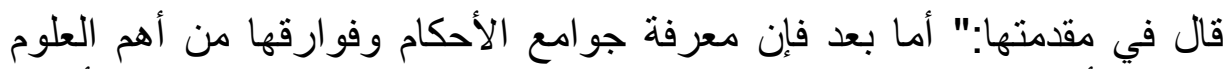

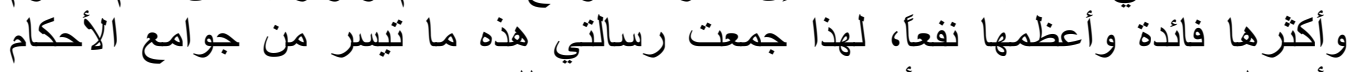
و أصولها، ومما تفترق فيه الأحكام لافتر اق حكمها و وعلاتها".

وقد ذكر فيها جوامع الأحكام وأصولها، وما تفترق فيه الأحكام لافتراق حكمها وافها

$$
\text { و علاها، وقسمها إلى قسمين: }
$$

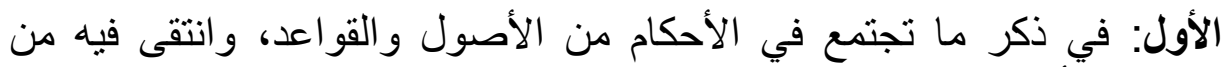

القو اعد المهمة و الأصول الجامعة ستين قاعدة، وشرحها شرحأ و افياً كما ذكر. الثاني: ذكر فيه الفروق بين المسائل والمشتبهات والأحكام المتقاربات و التقاسيم الصحيحة|(') - (1)

\section{هـ منظومة القواعد الفقهية وشرحها.}

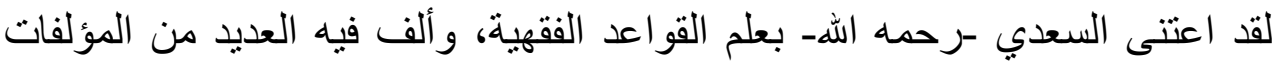

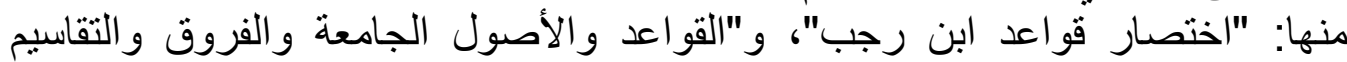

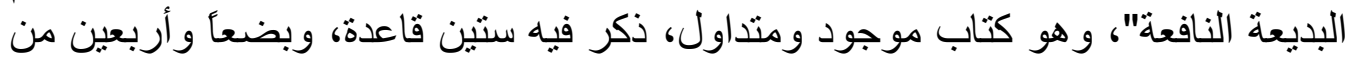

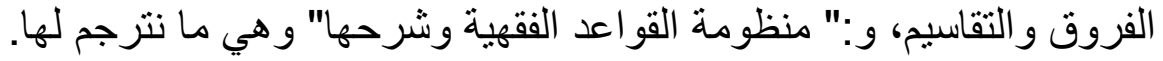

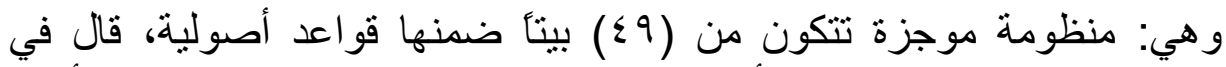

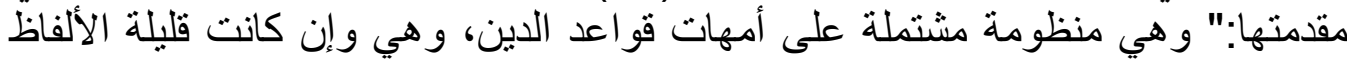

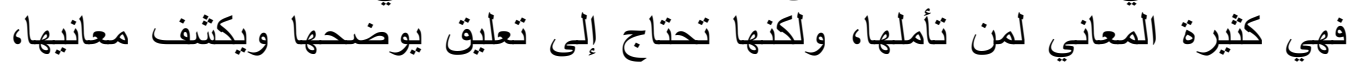

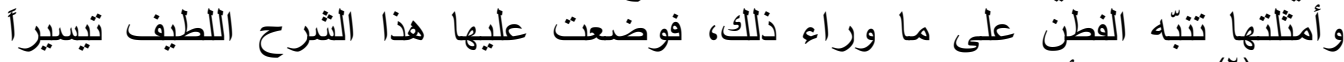

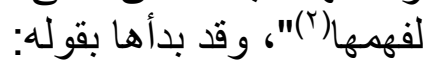

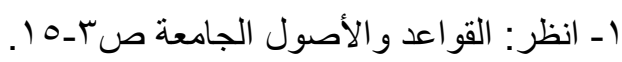

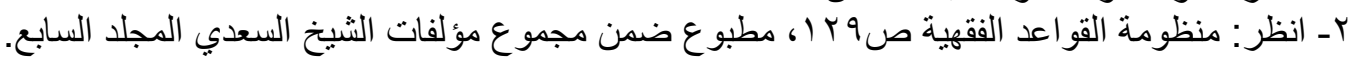




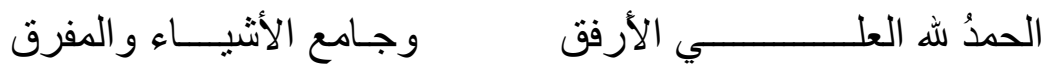

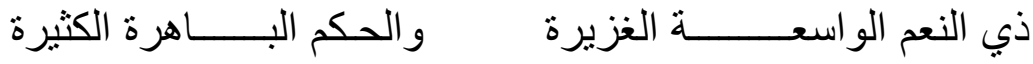

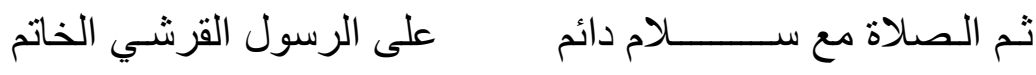

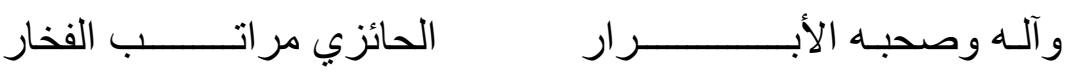

$$
\begin{aligned}
& \text { واختتمها بقوله: }
\end{aligned}
$$

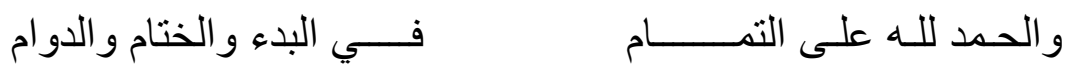

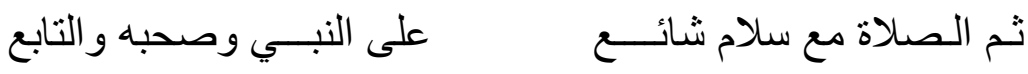

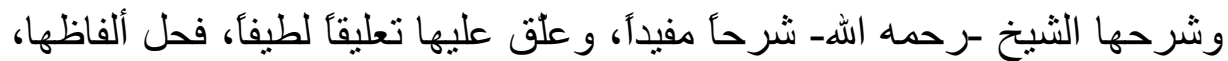

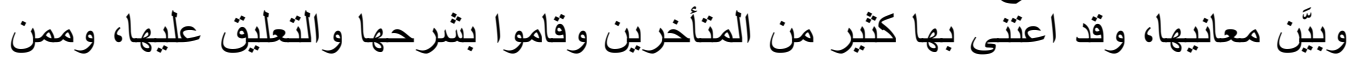

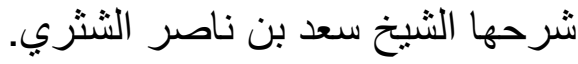




\section{البمش الثاني \\ طريقة الشيخ السعدي ومنهبه في هوالفاته الأصواية}

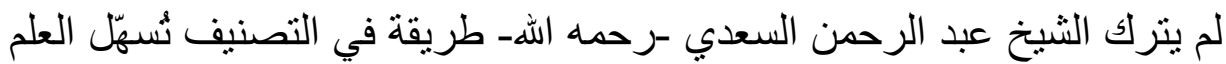

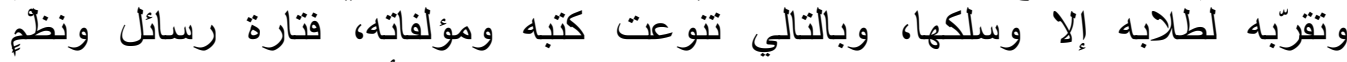

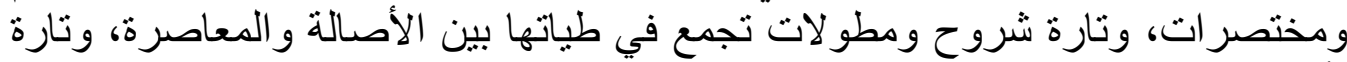

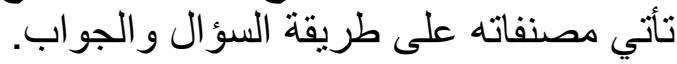

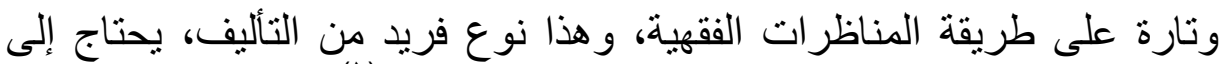

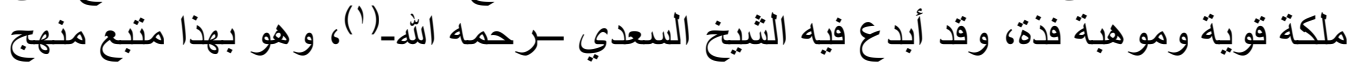

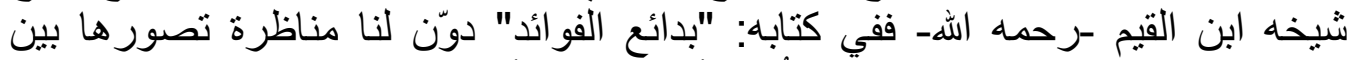

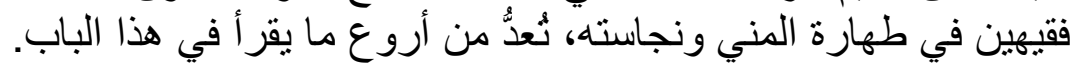

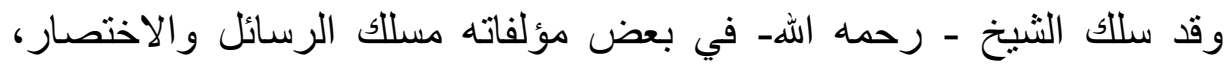

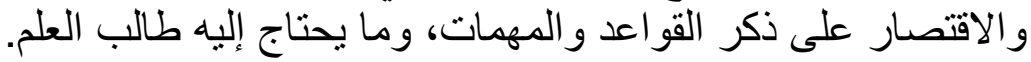

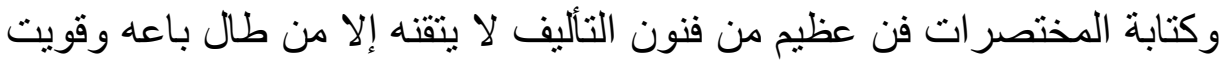
حجته، وتبحر في العلم، وصبر على البن البحث و المطالعة.

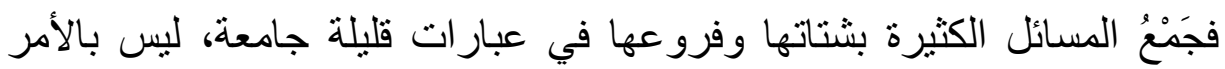
الهين -كما يعتقد البعض- بل هو فن محكم لا يتقنه إلإ الحدّاق.

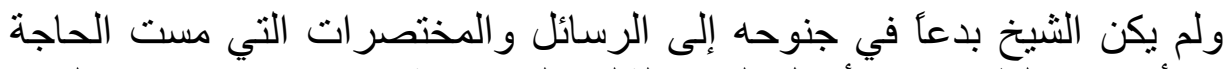

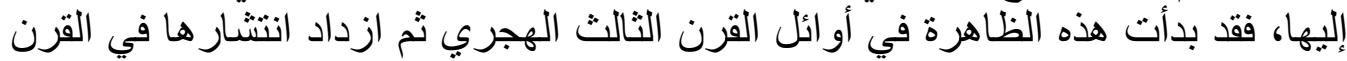
الر ابع ثم تضخم حجمها بشكل ملفت للانتباه في القرن السابع الهجري التهري. وسأقتصر في هذا المبحث على أهم النقاط التي تبين منهج الثيخ السعدي لني - رحمه الله- وطريقته في مؤلفاته الأصولية، وذللك في مطالب:

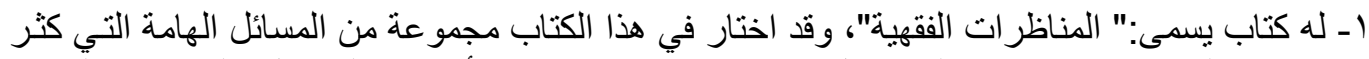

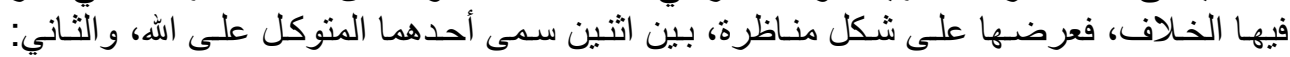
المستعين بالله، ثُ يدور الحوار ويتم الاستدلال والمناقثة حتى ينتهي إلى ترجيح أحد الر أيين لقوة الفئ 


\section{المطلب الأول}

\section{في تعربف أصول الفقةه}

عرّف الثيخ السعدي أصول الفقه في كتاب:" صفوة أصول الفقه المنتخبة"

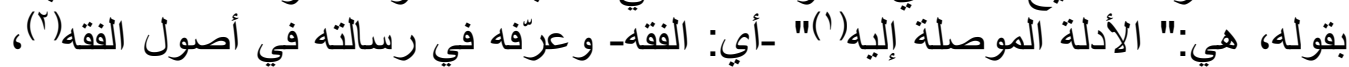

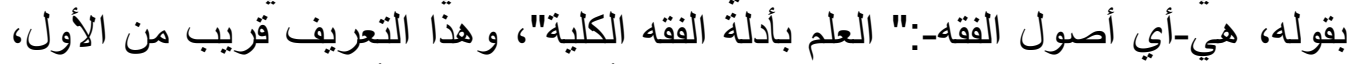

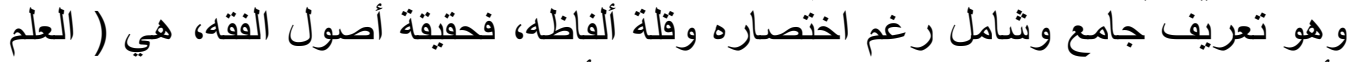

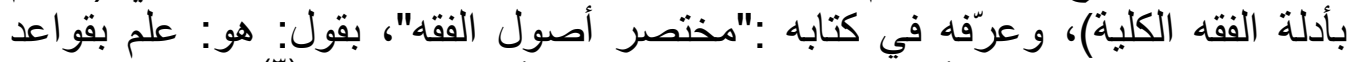
يتوصل بها إلى استتباط الأحكام الثرعية الثيابه :"لفرعية عن أدلتها التفصيلية(")".

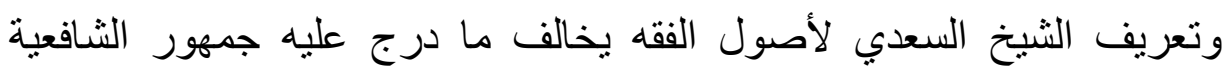

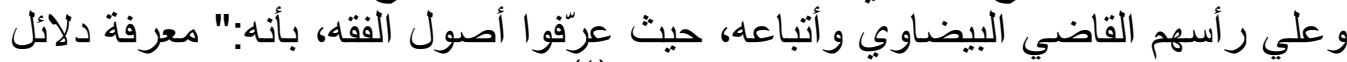

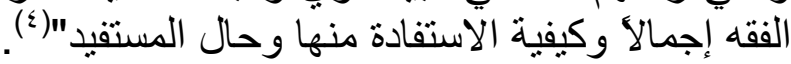

ويتو افق مع تعريف جمهور الأصوليين كابن الحاجب من المالكية، وابنه وابن مفلح

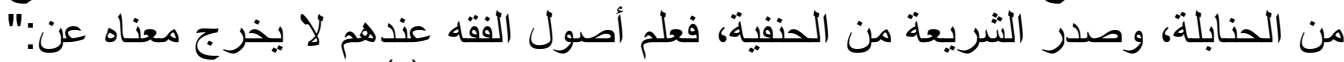

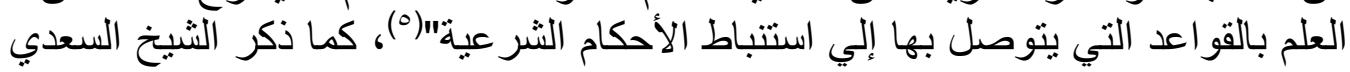
- رحمه الله- .

و: "العلم" معناه: المعرفة الحاصلة بطريق اليقين أو الظن، لأن الققه منه ما هو

قطعي ومنه ما هو ظني، بحسب ظنية الداليل وقطعيته.

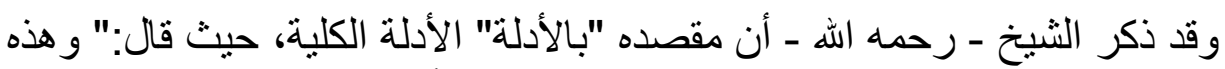

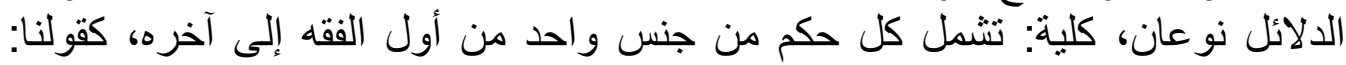

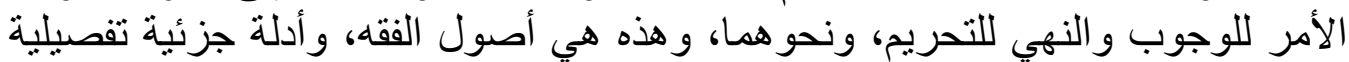

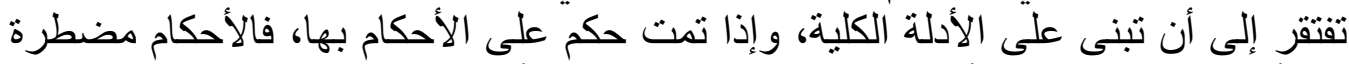

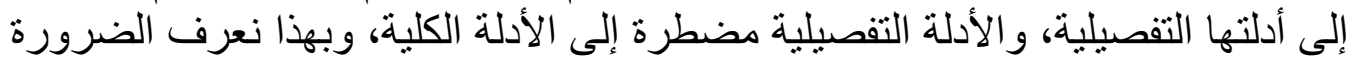

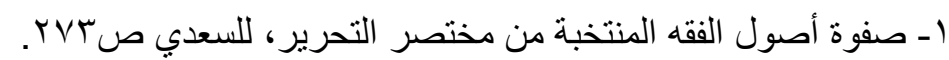

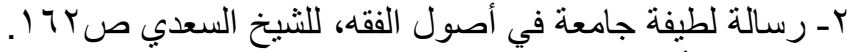

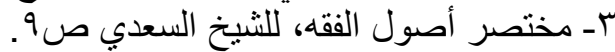

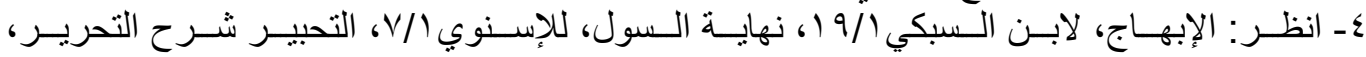

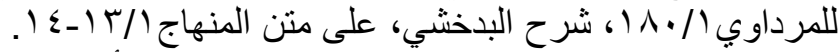

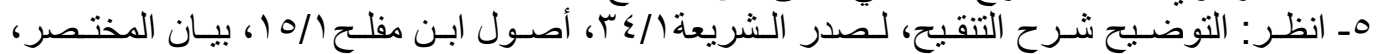

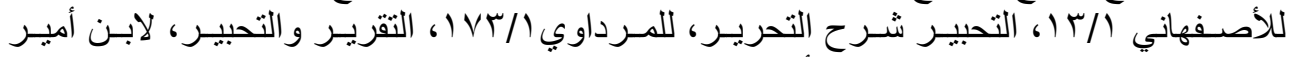

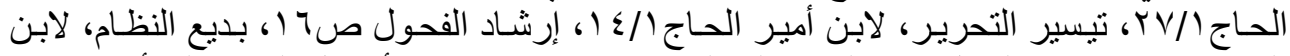

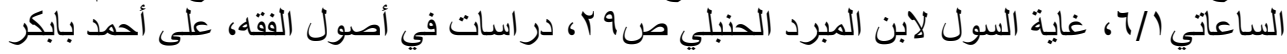

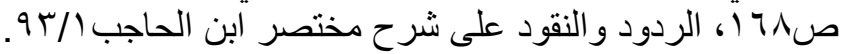


والحاجة إلى معرفة أصول الفقه وأنها معينة عليه، وهي أساس النظر والاجتهاد في الأحكام (')". (الحاجة

وقوله: "الكلية" احتر از عن العلم بالأدلة الجزئية كقوله تعالى:( وَأقِيمُوا الصئّلاةً

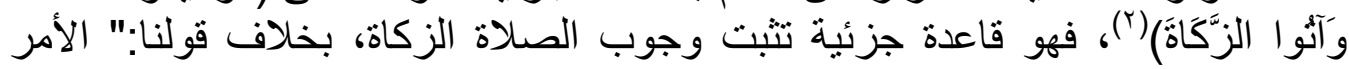

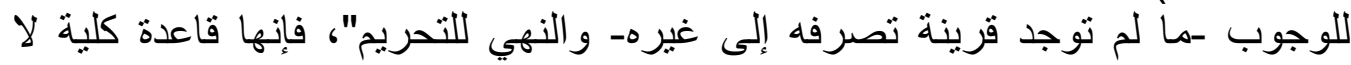
علاقة لها بحكم فرعي بعينه.

وقد يعترض على تعريف الثيخ السعدي: بأن أصول الفقه هو:" القواعد، أو أو ألفوبه

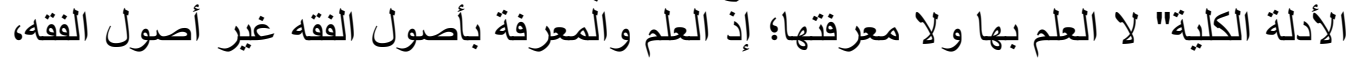

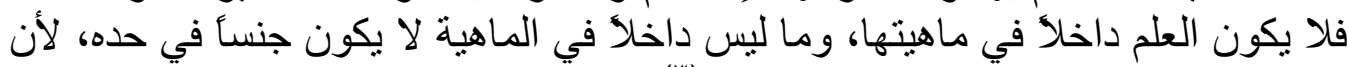

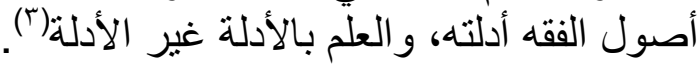

وقد يدفع هذا الاعتر اض: بأن العلم بالأدلة يوصل إلى بلى المدلول، والأدلة لا توصل الأله

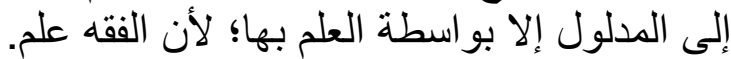

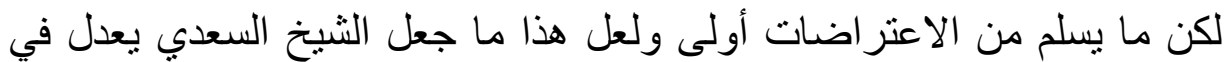

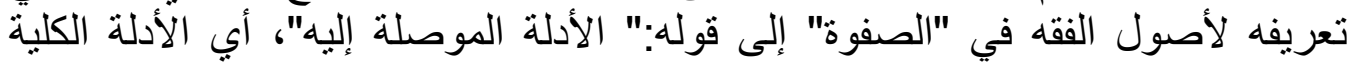

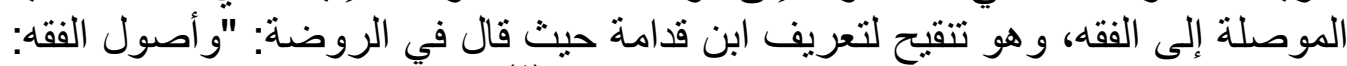

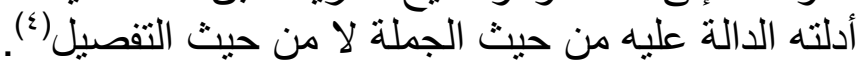

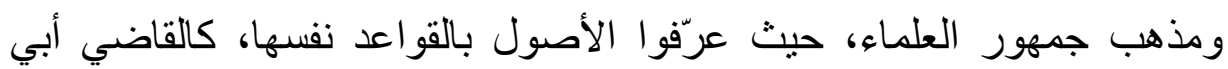

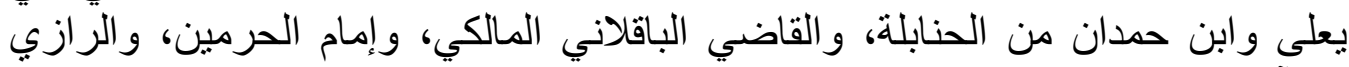
و اللأمدي واين ابن دقيق العيد و الإسنوي و غيلة ولفير هم من الثافعية.

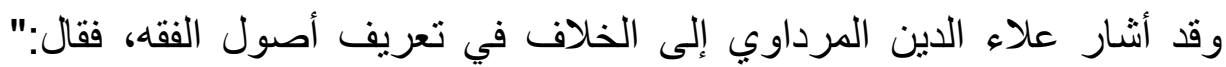

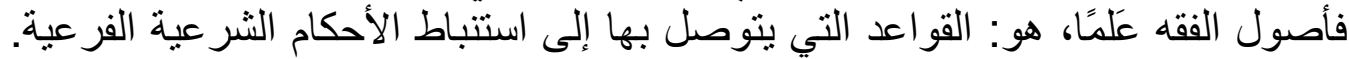

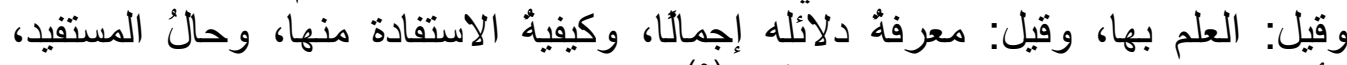

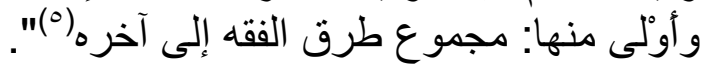

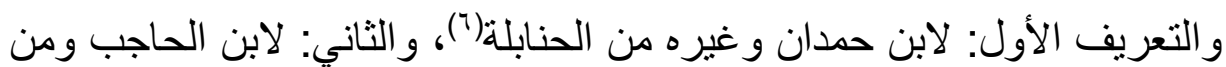

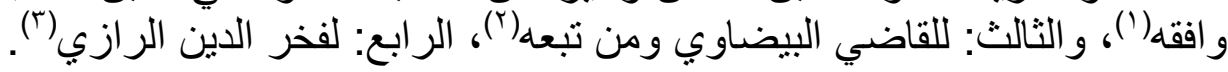

1- انظر: رسالة الثيخ في أصول الفقه، الموضع السابق.

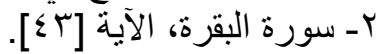

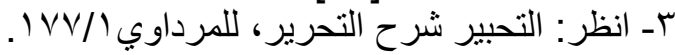

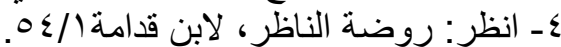

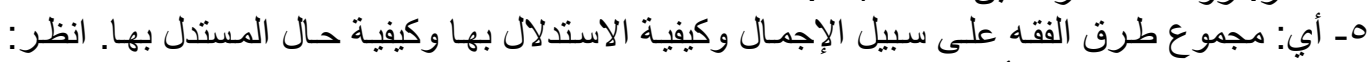

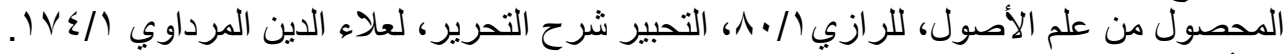

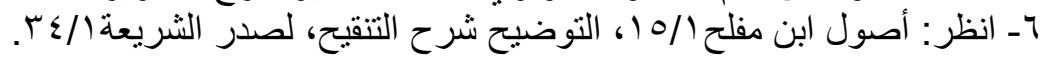




\section{المطلب الناني}

\section{الأدالة الثر عبة}

بدأ الثيخ -رحمه الله- بتعريف الدليل و التفريق بينه وبين الأمارة، فقال:

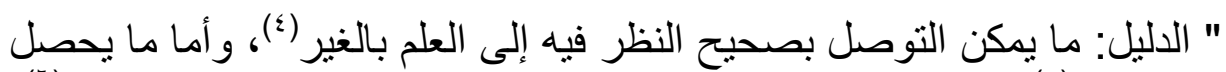

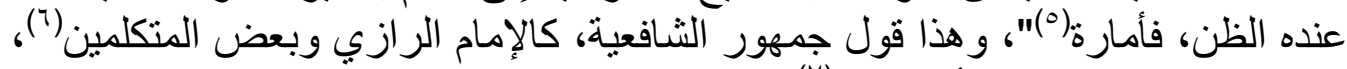

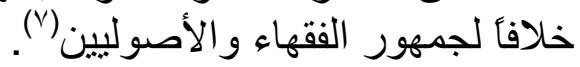

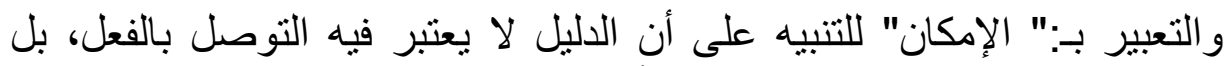

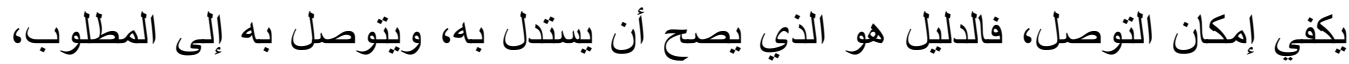

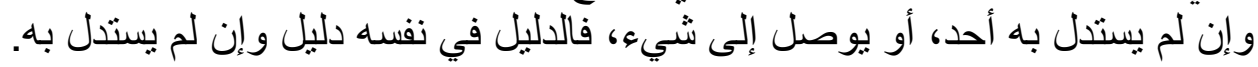

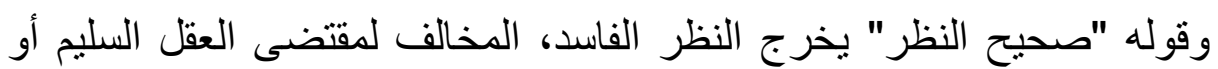

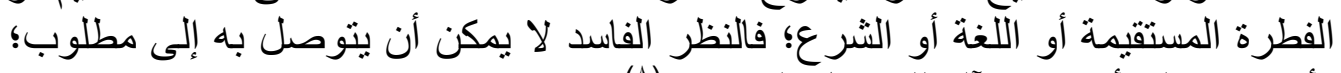

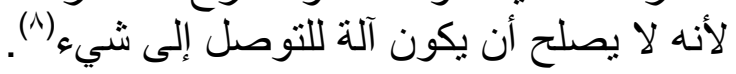

و الأدلة من حيث الاتفاق و الخلاف، نو عان: متفق عليها، ومختلف فئهاء لانها.

أولَا: الأدلة المتفق عليها.

بدأ الثيخ السعدي ـرحمه الله- بذكر الأدلة التي يستمد منها الفقه، وبدأ بالأربعة والإنها

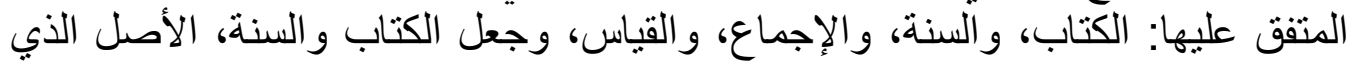

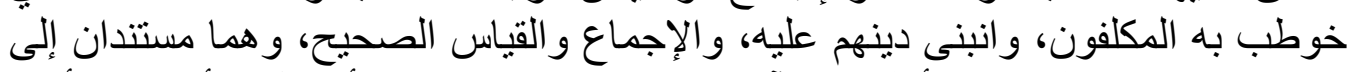

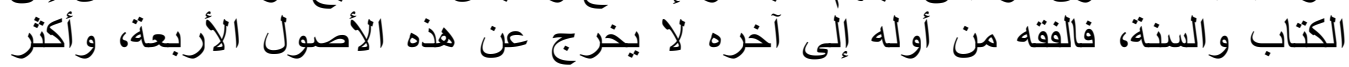

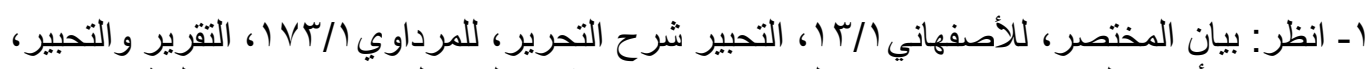

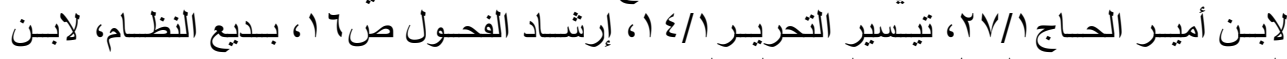

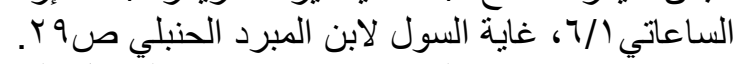

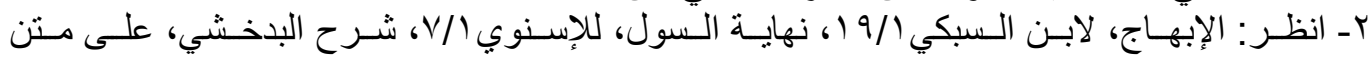

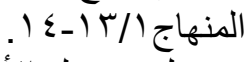

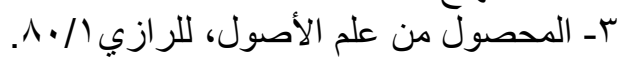

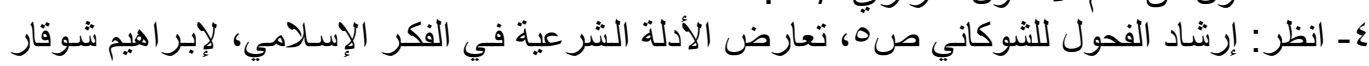
صع ז.

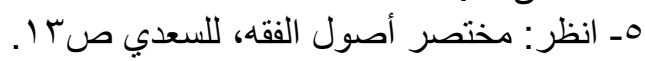

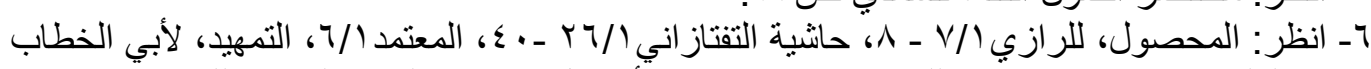

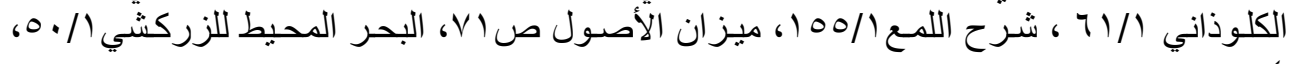

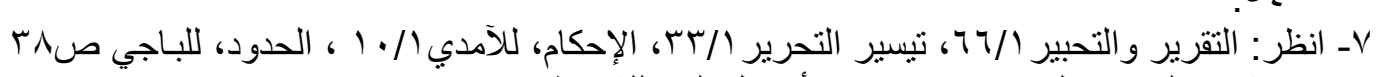

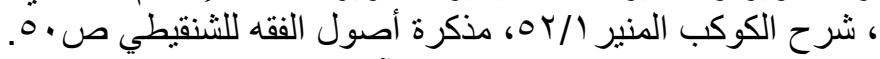

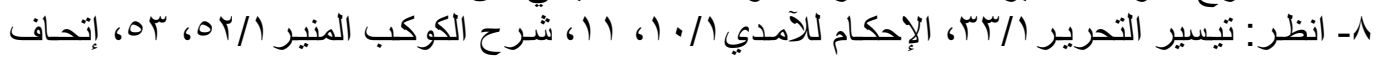




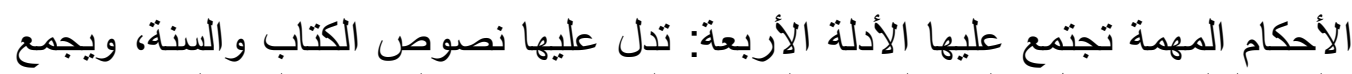

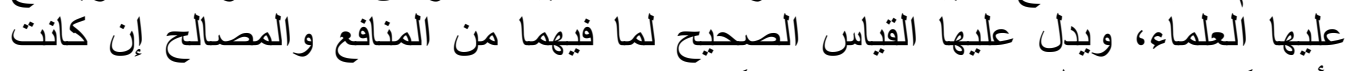
مأمور آ بها، ومن المضاه، وبدل عليها إن كانت منهياً عنها.

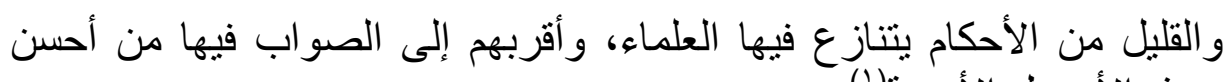

$$
\text { ردها إلى هذه الأصول الأربعة ('). }
$$

وقد عرّف الثيخ السعدي الأدلة الأربعة، وبدأ بالكتاب فقال: " هو القرآن المنزل

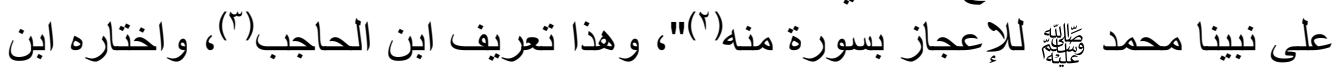
السبكي وغيره(£).

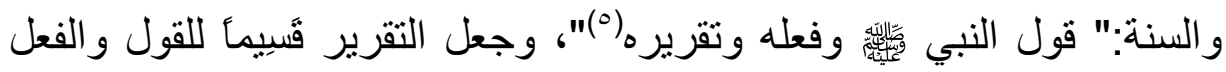

وهو مسلك جمهور الأصوليين(ج).

وبعض الأصوليين يقتصر علي الأقوال والأفعال فقط، وهو صنيأليع أبي بكر الجصاص و القاضي البيضناوي و أتباعه (Y).

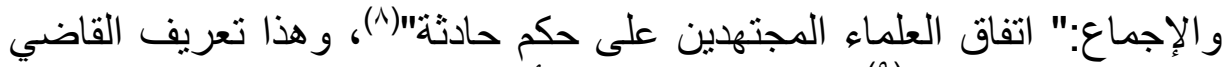

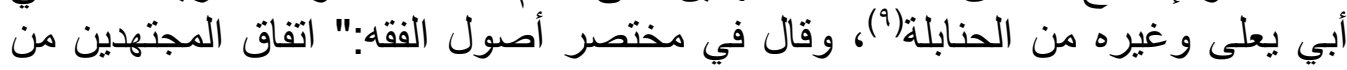

1 - رسالة الشيخ السعدي صعء، شرح رسالة لطيفة في أصول الفقه، سعد الشثري ص • 7ـــ 7.

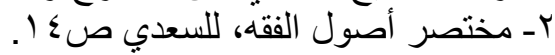

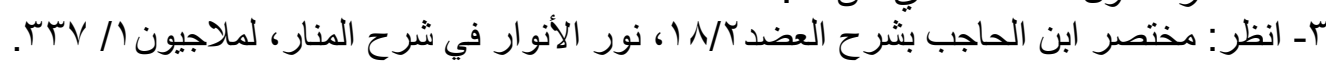

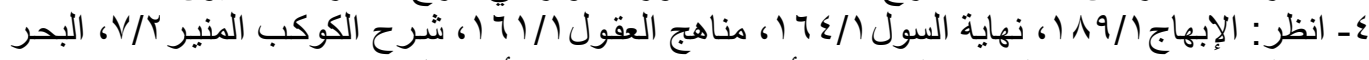

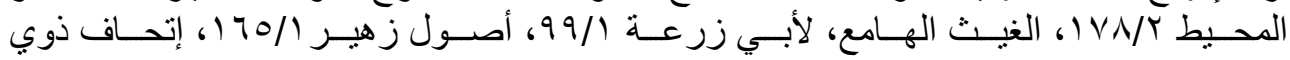

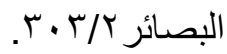

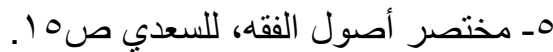

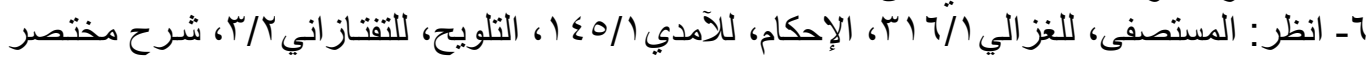

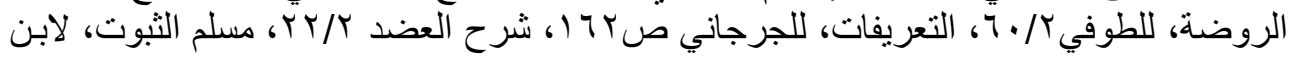

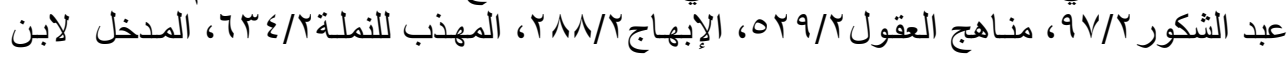

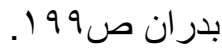

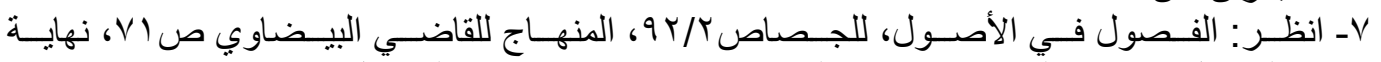

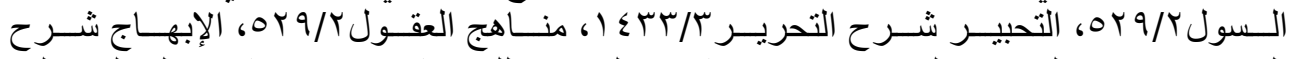

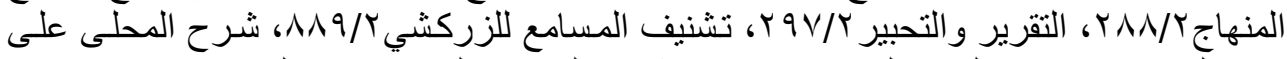

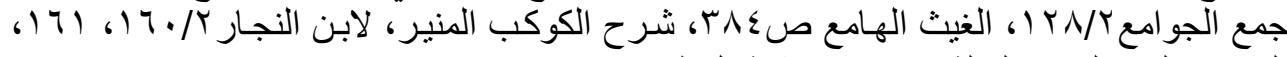

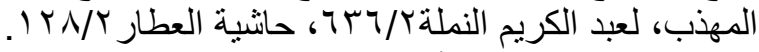

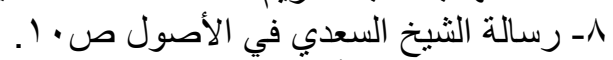

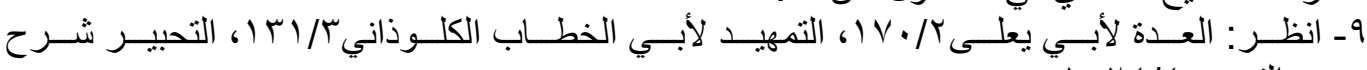




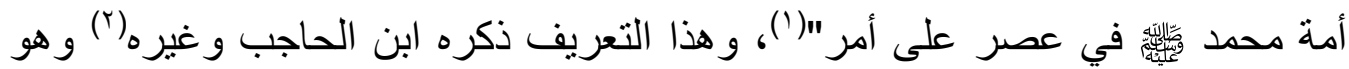

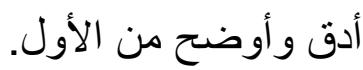

وبعض الأصوليين كالغز الي وابن قدامة قيّد الأمر المجمع عليه بكونه دينياً، فلا

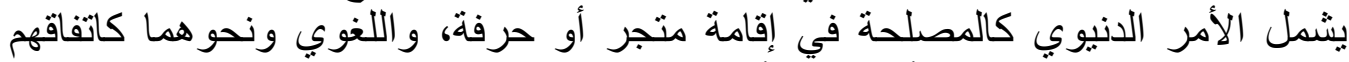

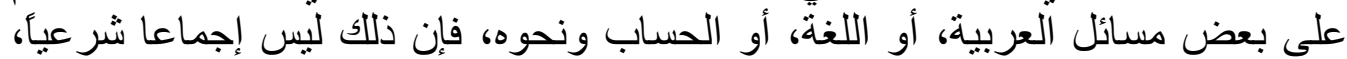

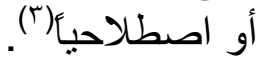

وذكر القياس وتعريفه و أقسامه و أركانه وشروطه ومسالكه وقو ادحه، وقد وضح

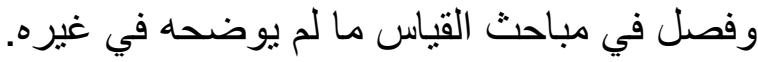

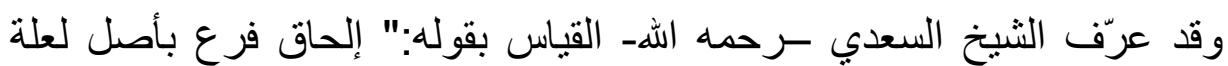

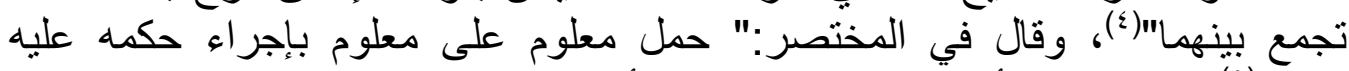

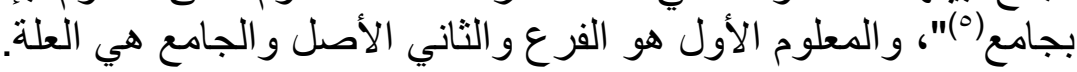

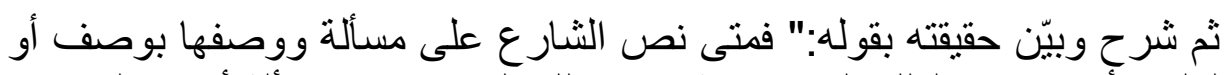

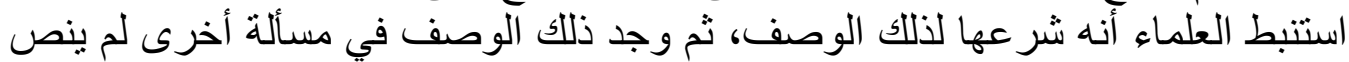

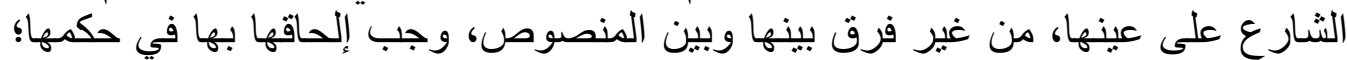

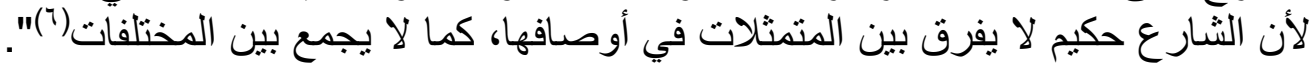

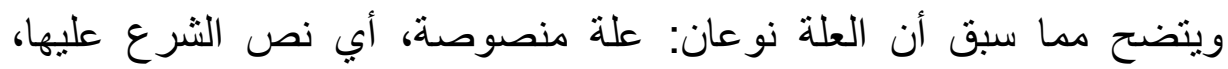

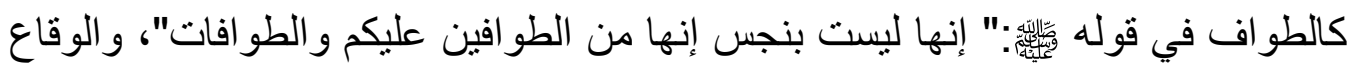
في حديث أبي هريرة: "وقعت على امرأني في نهار رمضان، قال:" أعتق"، وقد تكون

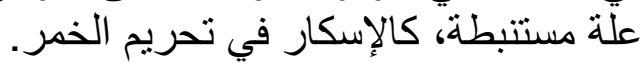

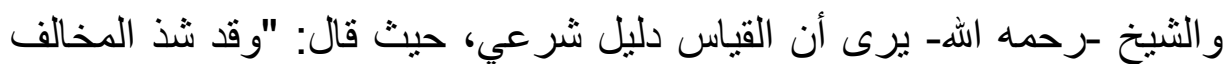

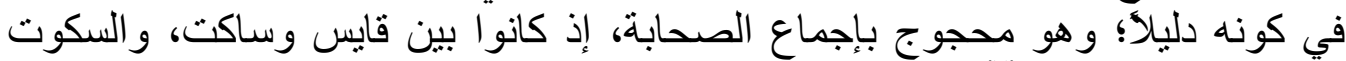

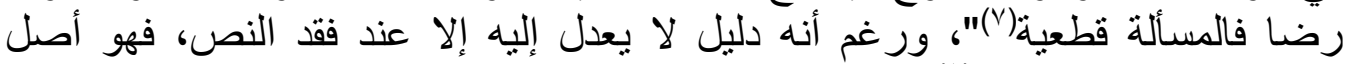
يرجع إليه إذا تعذر غيره(^).

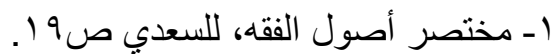

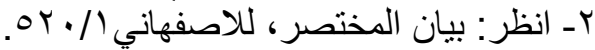

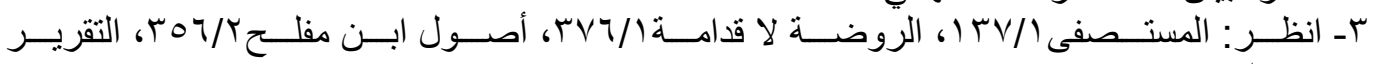

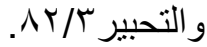

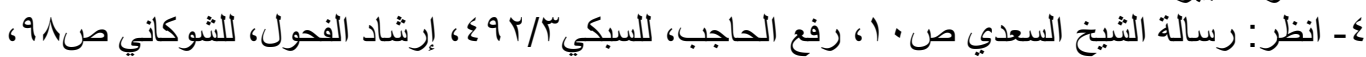

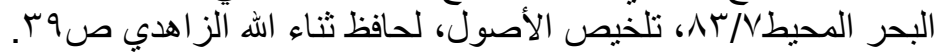

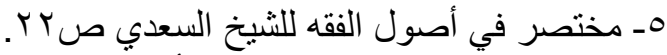

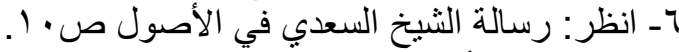

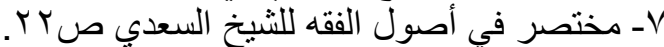

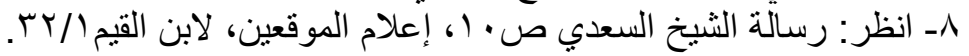




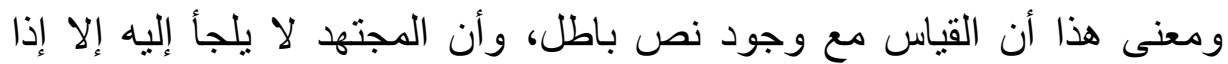

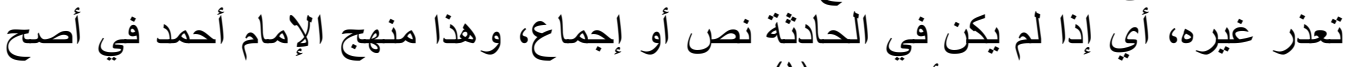

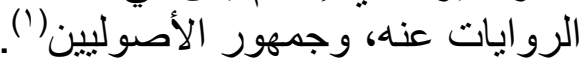

\section{ثانياً: الأدلة المختلف فيها.}

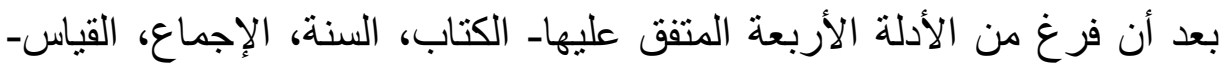

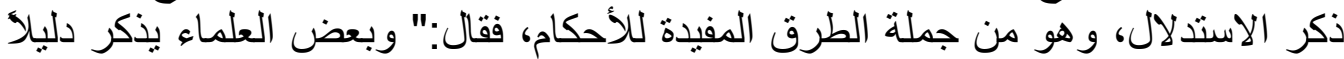

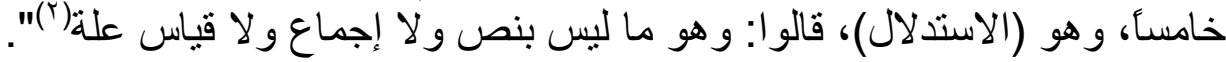

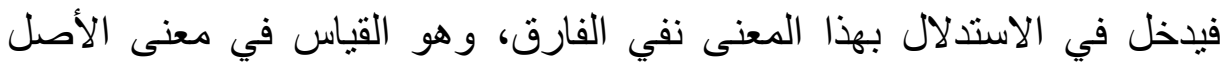

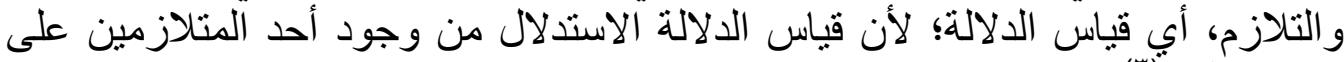

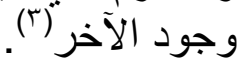

وهو ثلاثة أنواع: الأول: تلازم بين الحكمين من غير تعيين علة، مثل: من صح ظهاره صح طلاقه.

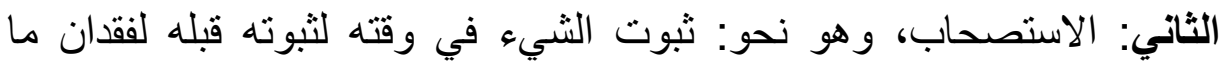

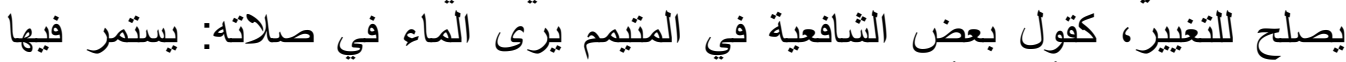
استصحابأ للحال الأول؛ لأنه قد كان وجب عليه المضي في فيها قبل الرؤية.

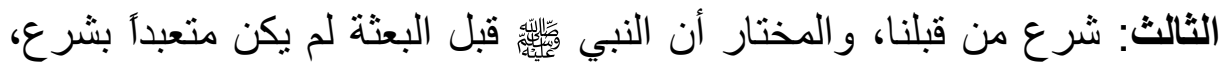

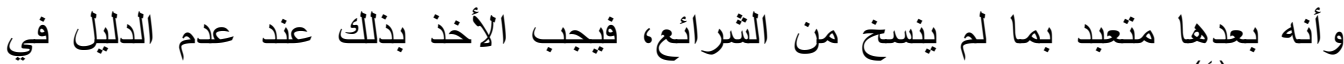

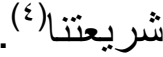

قيل: ومنه الاستحسان، وهو عبارة عن: دليل يقابل القياس الجلي، وقد يكون

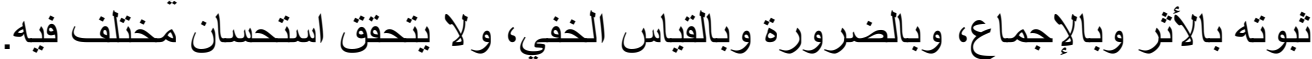

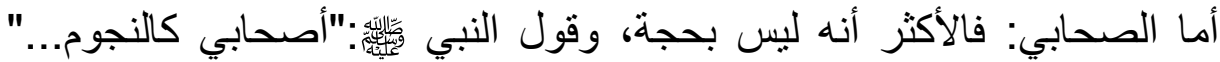
الخبر، ونحوه المر اد به المقلدون(ن)".

وفي كتابه: "رسالة لطيفة جامعة في أصول الفقه المهمة" عرّف السعدي قول

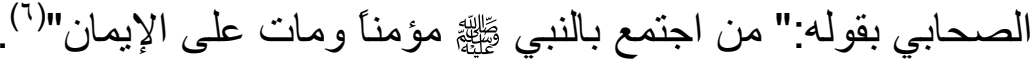

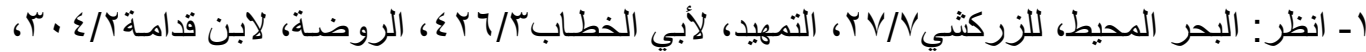

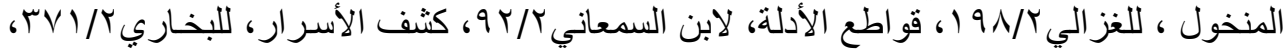

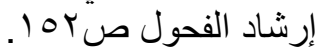

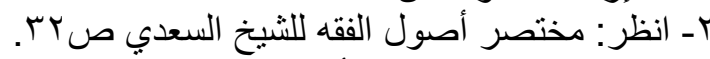

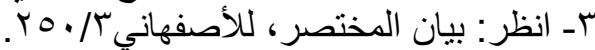

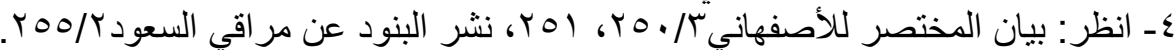

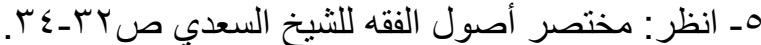

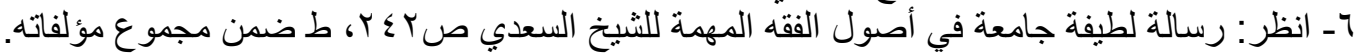


و هذا تعريف الإمام أحمد وكثير من الأصوليين(') واختاره الأمين الثنقيطي(r)

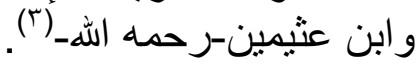

ثم قال:" إذا قال أحد الصحابة قولا و واثتهر بين الباقيين، فإن ظهر منهم موافقة

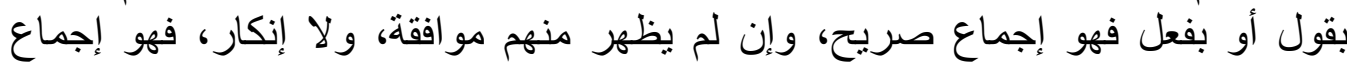

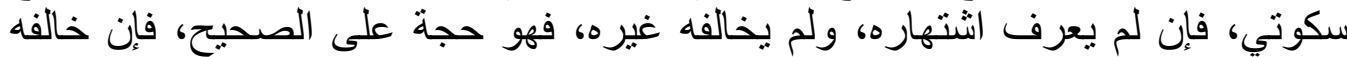

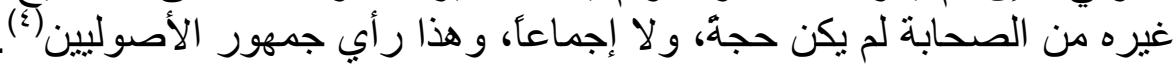

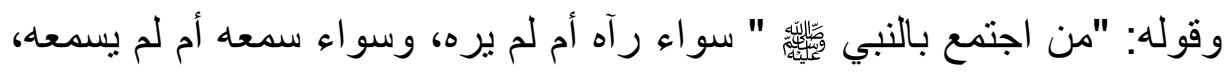

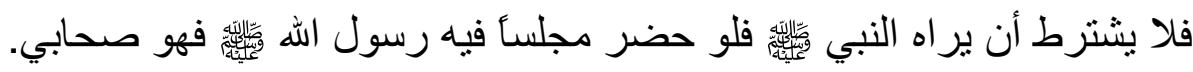

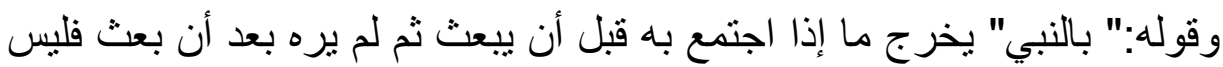

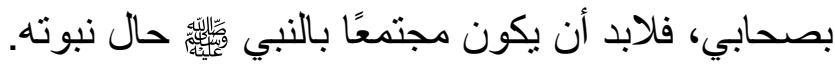

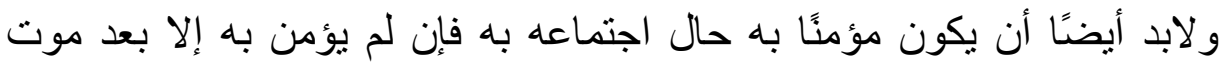

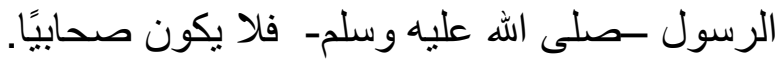
وقوله: "ومات على ذلك" يخرج ما إذا ارتد؛ لأن الردة تمحو حتى الإسلام فضلا

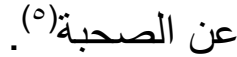

\section{المطllliلف}

\section{الأحكام الشر عية}

ذكر الثيخ السعدي- رحمه الله- الأحكام الشرعية ومتعلقاتها، أما الأحكام، فقال

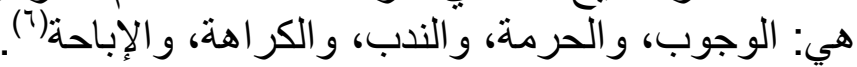

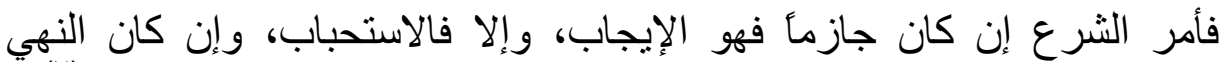

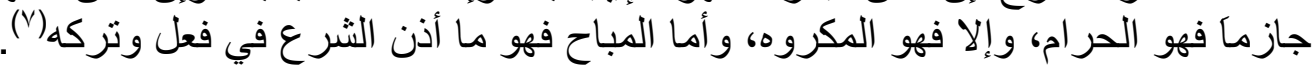

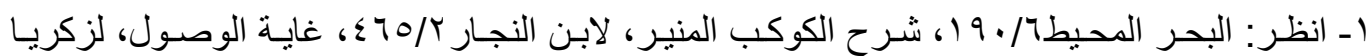

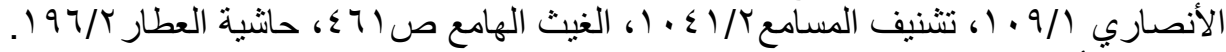

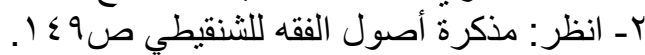

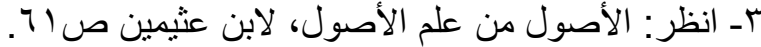

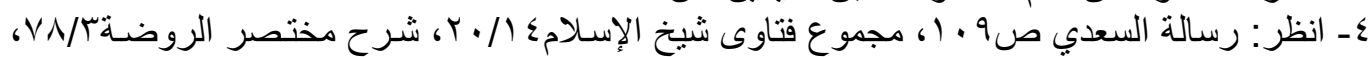

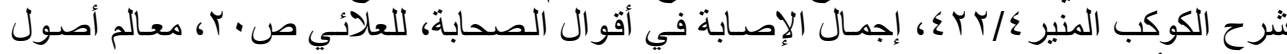

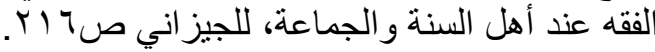

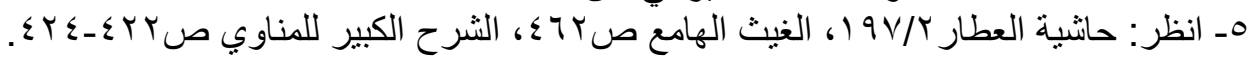

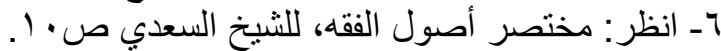




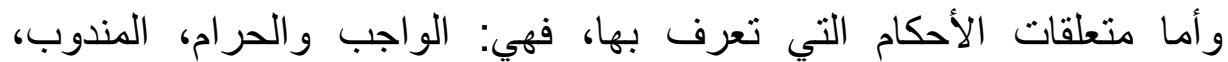

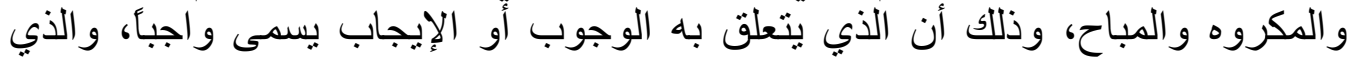

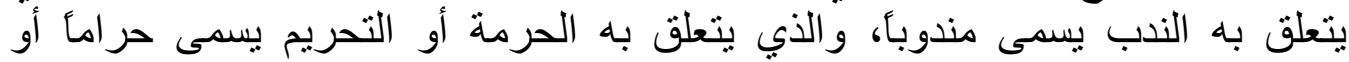

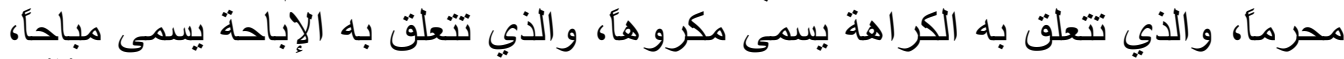

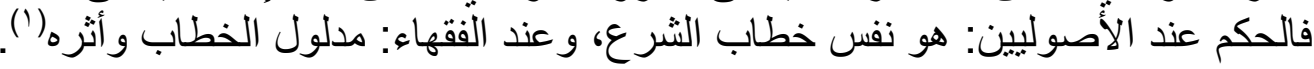

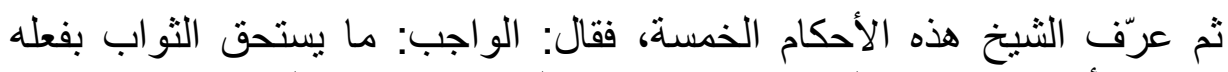

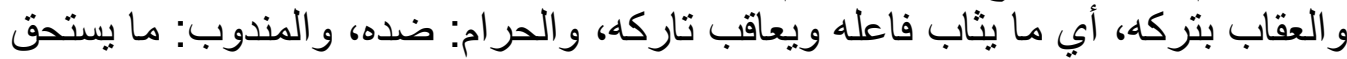

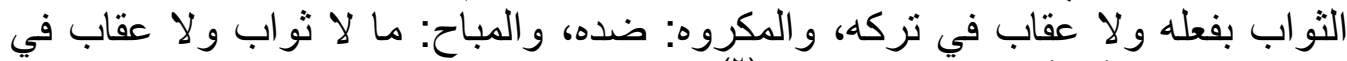

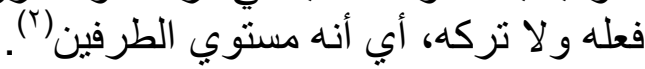

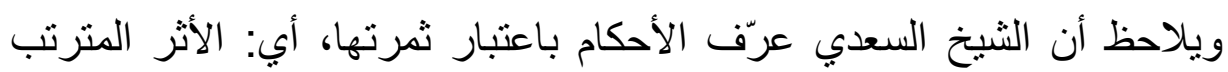

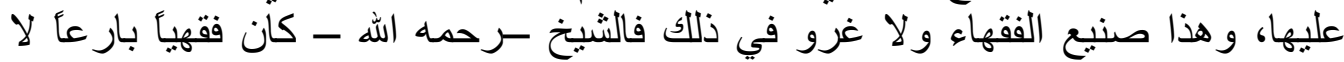

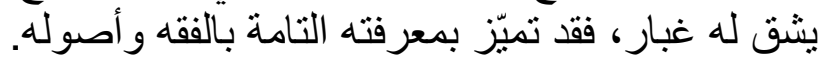

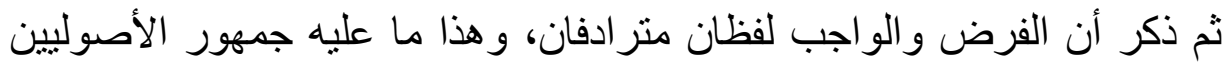

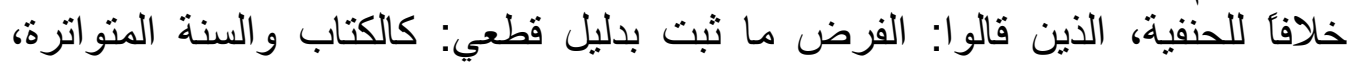

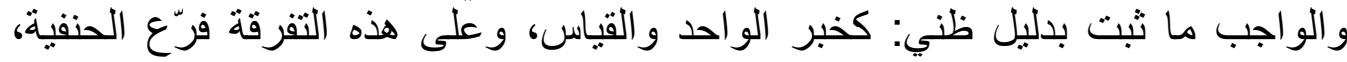
فقالو ا: إن تارك الفرض جاحدآ يكفر، بخلاف تارك الت الواجب.

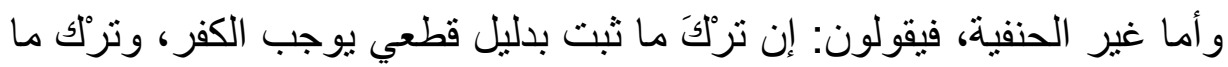

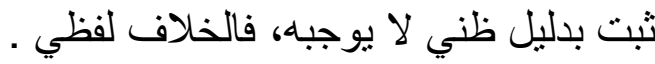

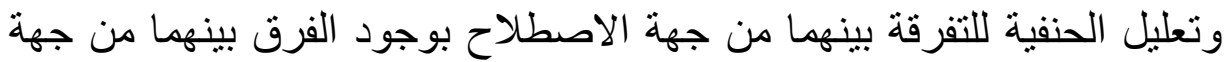

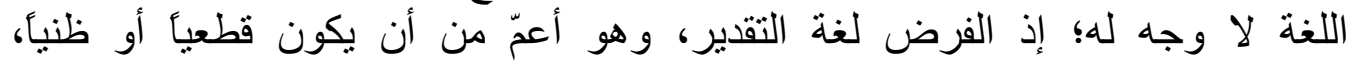
فتخصيصه بالتقدير القطعي لا وجه لله في اللغة. لأله

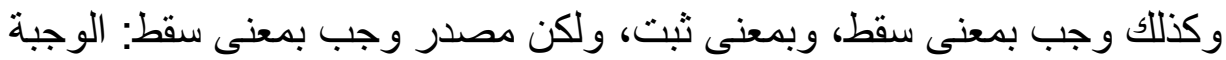

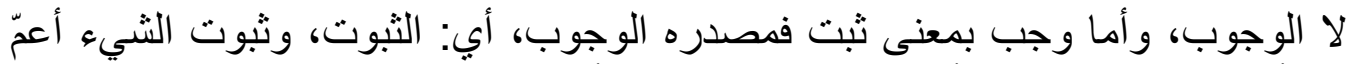

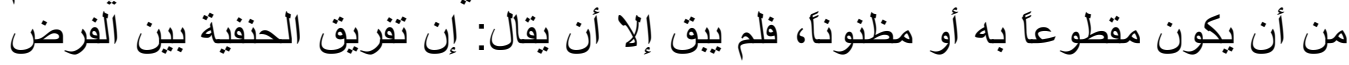

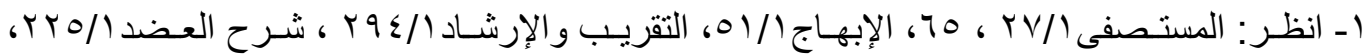

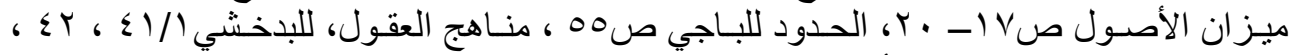

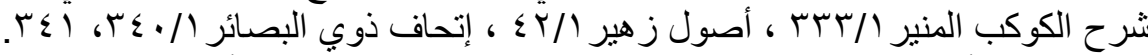

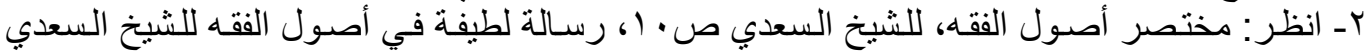




$$
\text { و الو اجب مجرد اصطلاح '('). (') }
$$

ثم ذكر تقسيمات الواجب باعتبار اته المتعددة: فباعتبار الفعل المكلف بها، ينقسم

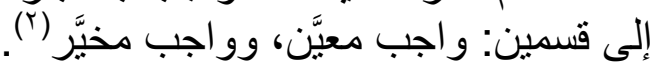

فالواجب المعيَّن، هو: ما طلبه الثارع من المكلف فعله بعينه، دون تخيير بينه وبين شيء آخر، مثاله: الصلاة و الزكاة، ونحو ذللك من الو اجبه الهبات.

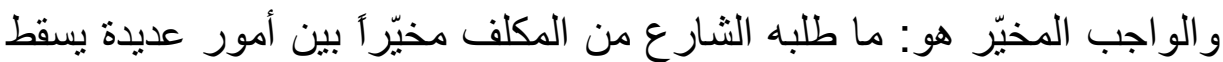

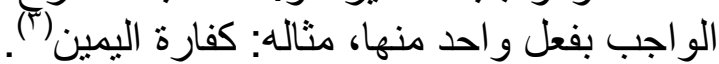

وينقسم باعتبار المخاطب بفعله، أي المكلف، إلى: واجب عالب عيني وهو: ما يطلب فعله من كل مكلف بالغ عاقل، وهو جمهور أحكام الثريعة الو اجبة. و إلى كفائي، وهو: الذي يطلب حصوله وتحصيله من المكلفين، لا من كل و احد احد

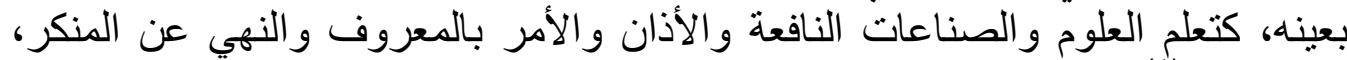

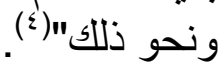

وحكم الواجب العيني التزام كل مكلف به و وعدم براءة ذمته منه إلا بالأداء

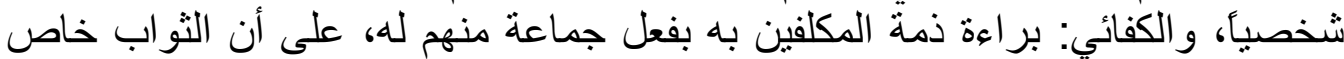
بالجماعة التي قامت به دون غير ها، فإذا تركوه جميعا أثمو اله كلهم (ه)

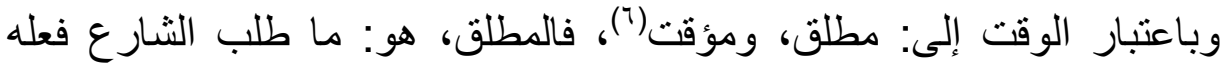

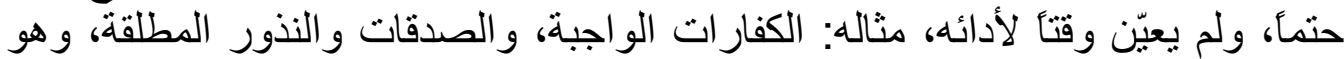

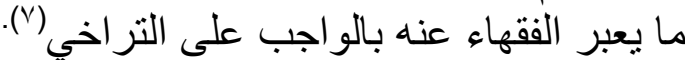

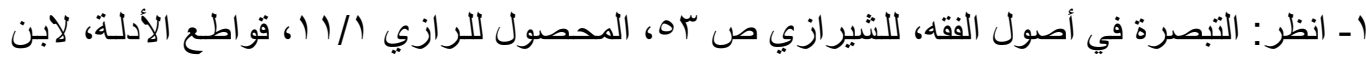

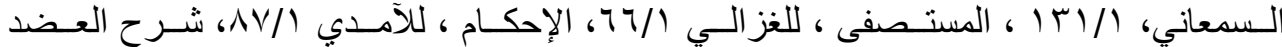


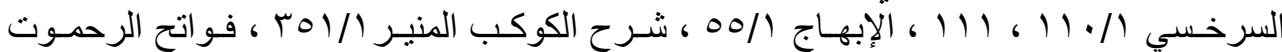

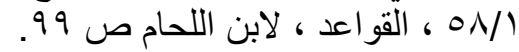

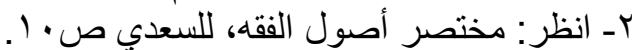

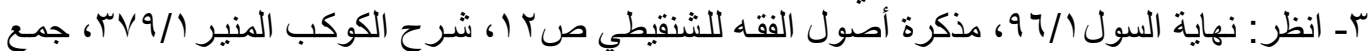

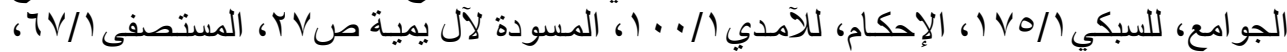

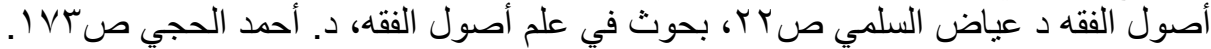

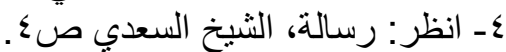

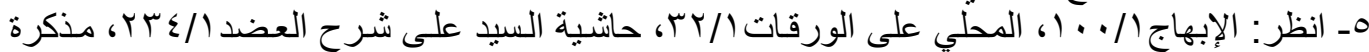

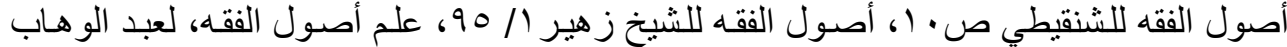

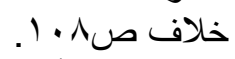

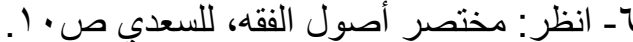

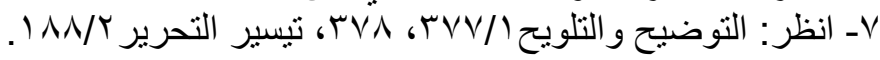




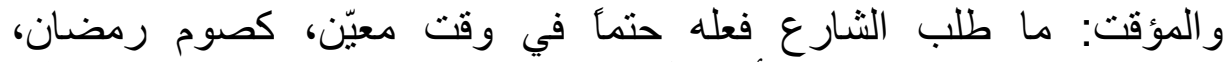

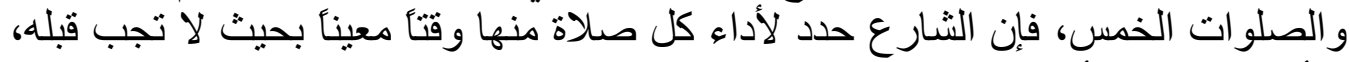

ويأثم المكلف إن أخّر ها عنه بغير عذر الخمان (1).

$$
\text { وينقسم المؤقت إلى: مضيق، وموسع (r). }
$$

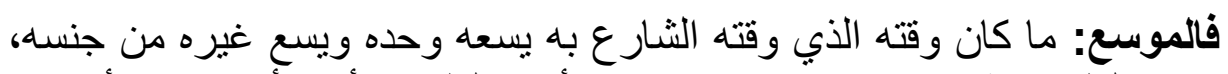

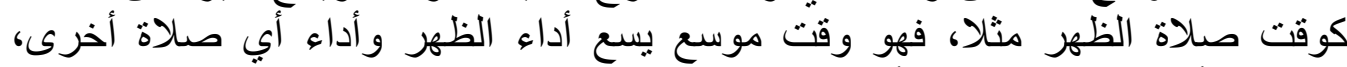
وللمكلف أن يؤدي الظهر في أبي جزء منه.

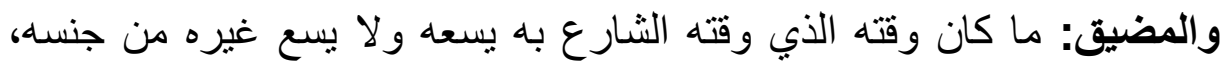

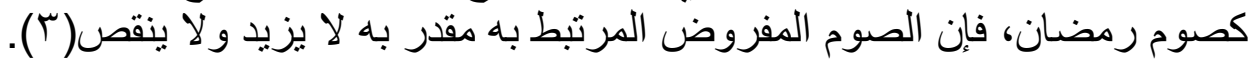

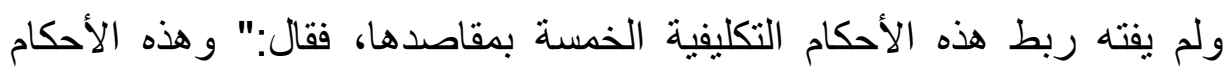

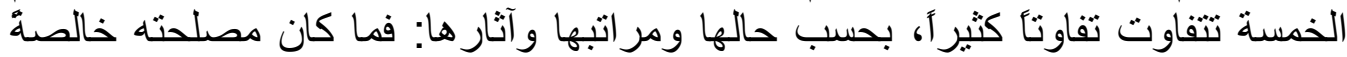

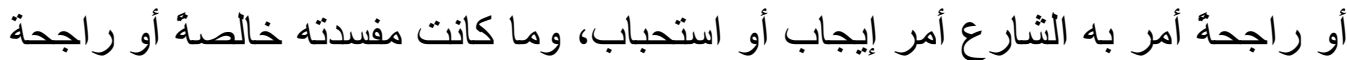
نهى عنه الثارع نهي تحريم أو كر اهة.

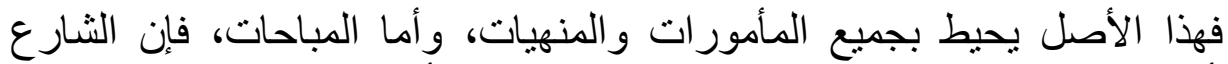

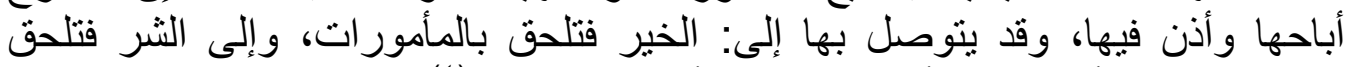

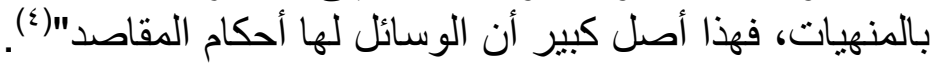

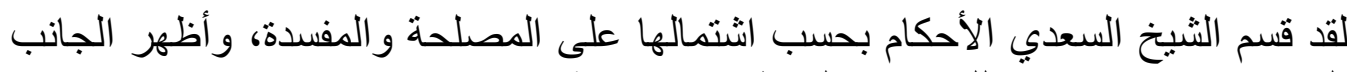
المقاصدي فيها وهو مسلك الإمام الثـاطبي رحمه الله.

\section{المطلب الرابـم}

\section{دلالات الألفاظ}

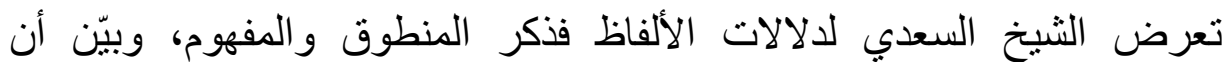

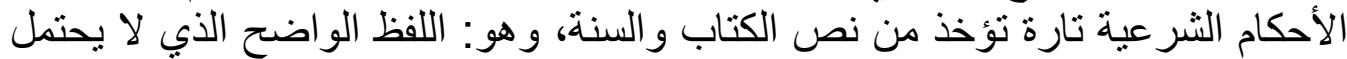

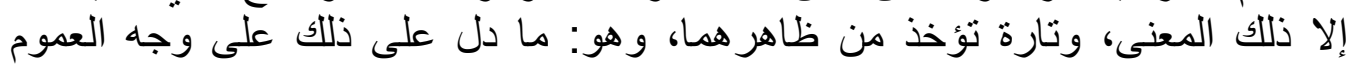

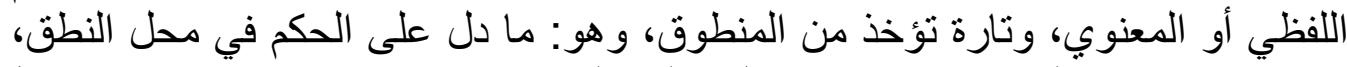

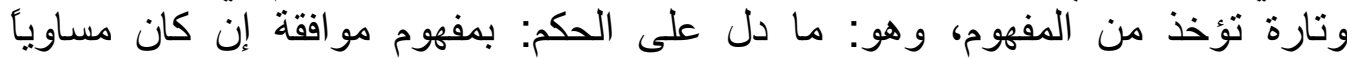

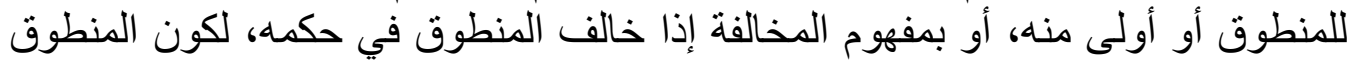
وصف بوصف أو شرط فيه شرط، إذا تخلف ذللك الوصف أو الثرط في تخلف الحكم.

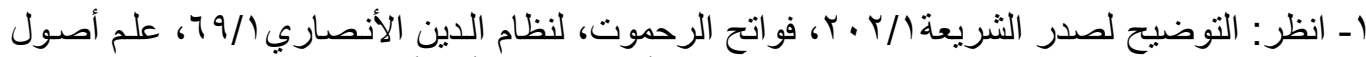

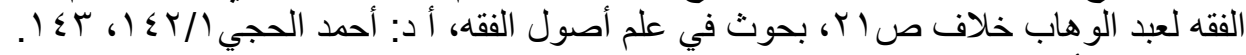

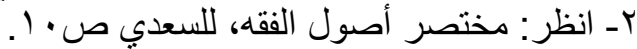

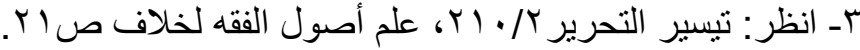

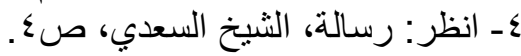


و أن دلالة ألفاظ الكتاب و السنة على معانيها: تارة تكون بالمطابقة: إذا طبقنا اللفظ

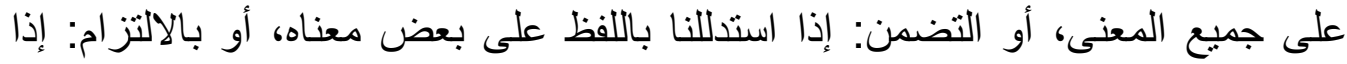
استدللنا بلفظ الكتاب و السنة ومعناهما على تو ابع ذلك ومتمماته.

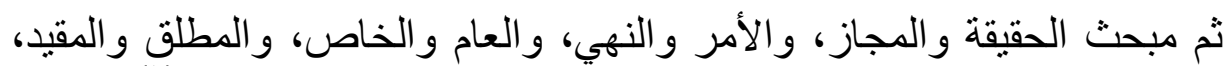

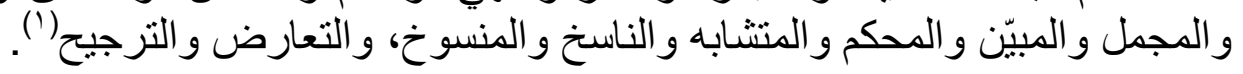

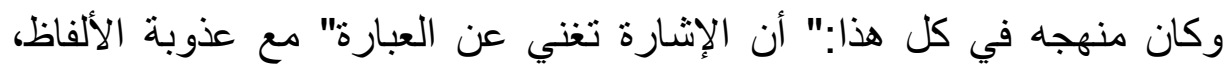

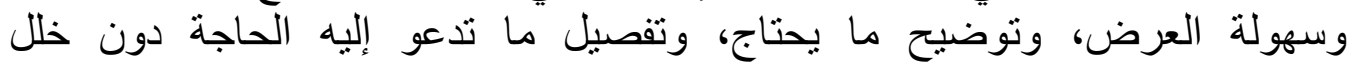

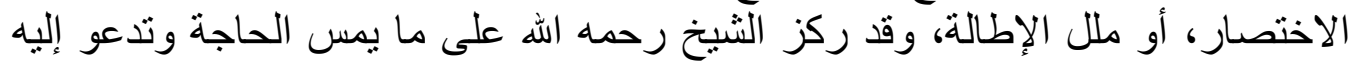

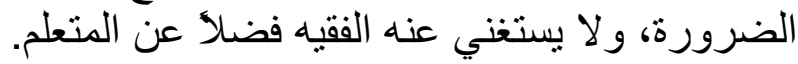

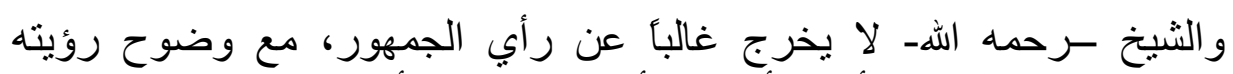
واستقلال شخصيته، والعجيب أنك وأنت تقرأ في مؤلفاته كأنك تسمع الثنيخ يخاطبك ويتحدث إليه.

لكن بلاحظ عدم تقيده بطريقة الجمهور في العرض والترتئ، فئه فقد يبدأ في الكلام عن شيء ثم يتركه ويتكلم عن شيء آخر ثم يعود إليه مرة أخرى، وفي طريقة فئن التأليف هذه كسر للملل وتنثويق للقارئ.

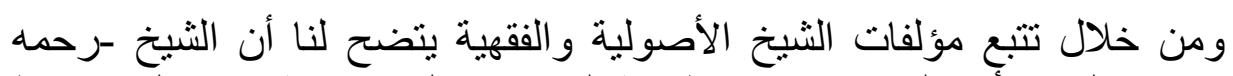

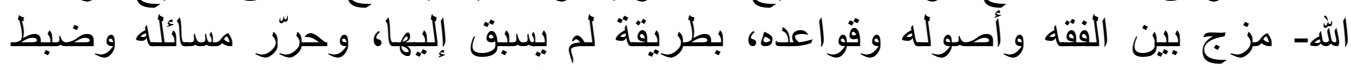
قو اعده، مقتصر أ على ذكر المهمات التي يحتاج إليه كل متعلم وفقيه.

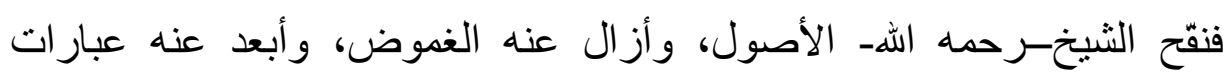
المتكلمين، وفلسفة المتفلسفين، وما لا ينبني عليه حكم شر عي.

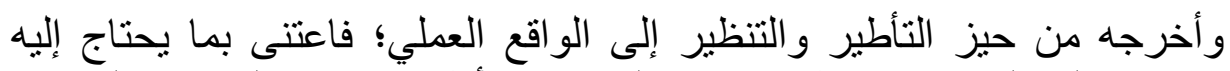

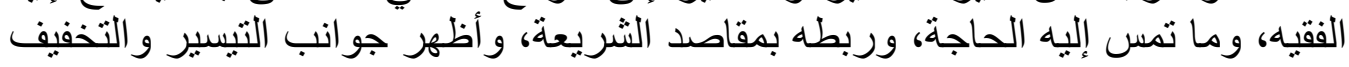
فيها.

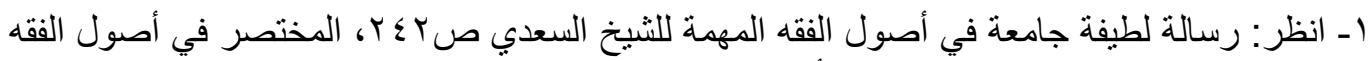

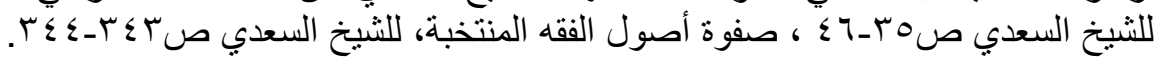




\section{المبمث الثالث}

\section{هنهج الشيخ السعدي وطريقته في الاستنباط}

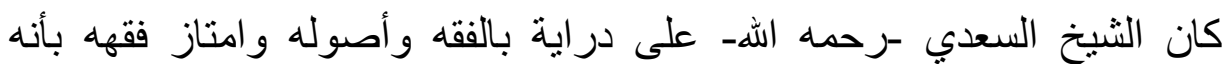

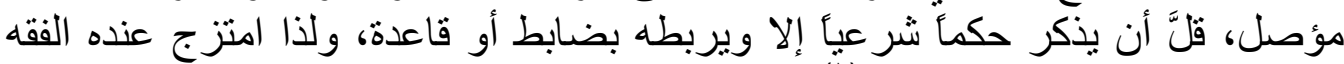
بالأصول وربط الفروع بالقو اعد (').

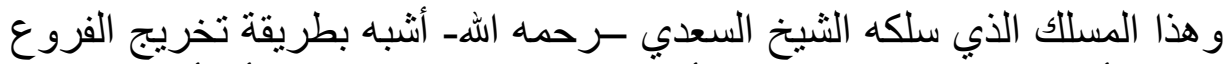

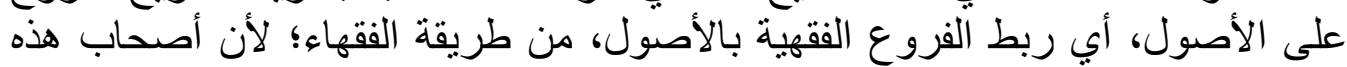

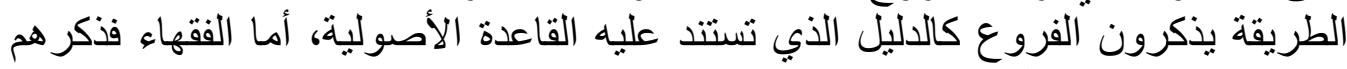
للفروع إنما هو للتمثيل والتفريع فقط التط.

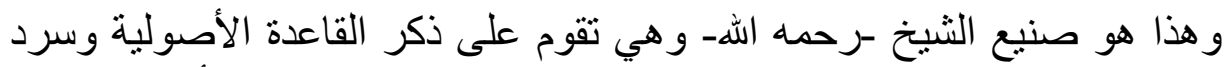

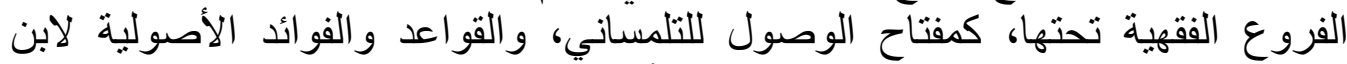

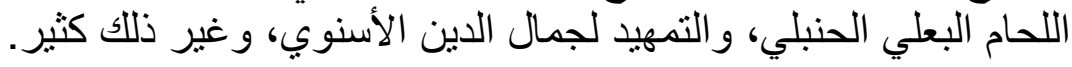

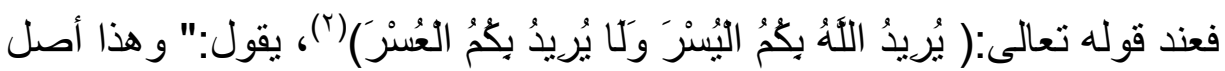

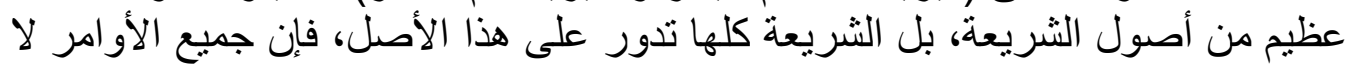

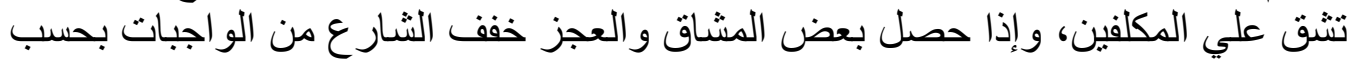

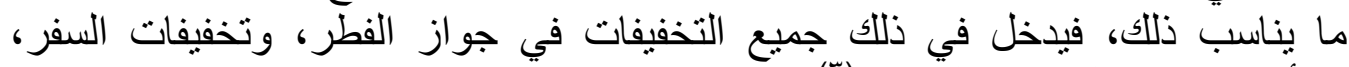

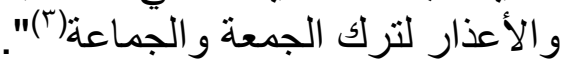

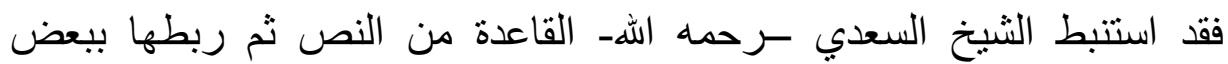
الفروع الفقهية التي توضحها.

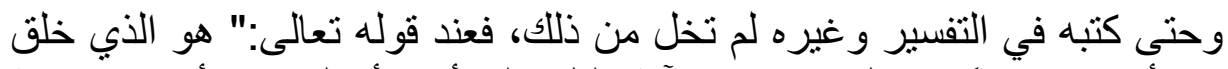

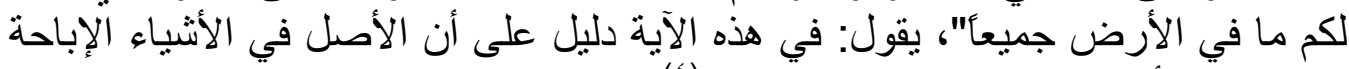
و الطهارة؛ لأنها سيقت في معرض الأرضع الامتنان (ء).

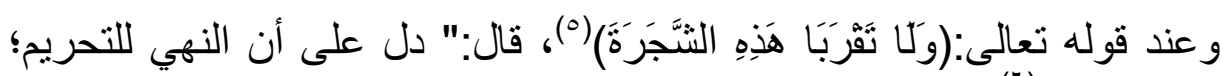
لأنه رتب الظلم عليه(؟).

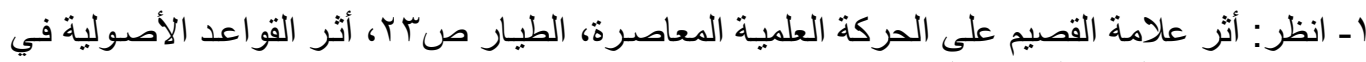

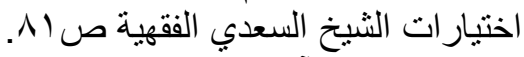

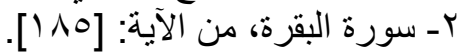

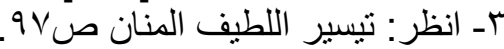
ــ انظر : تيسير الكريم الرحمن في تفسير كلام المنان ص. • بـ، أثر القو اعد الأصولية في اختيار ات الثيخ

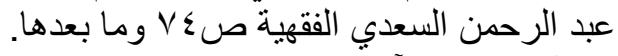

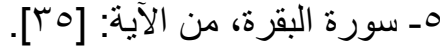

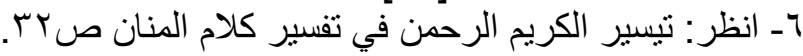




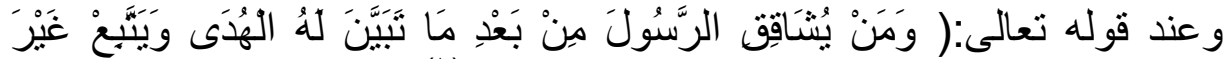

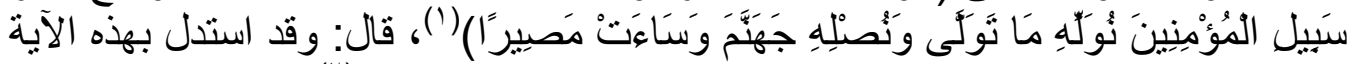

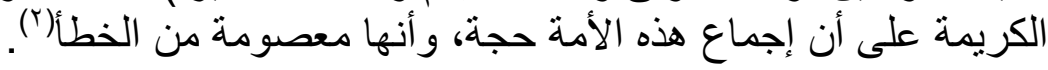

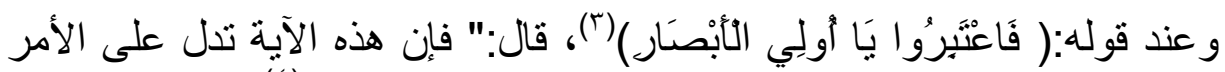

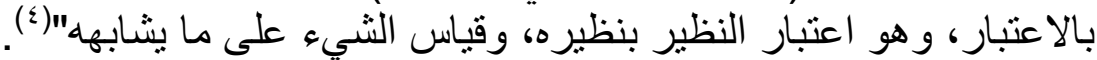

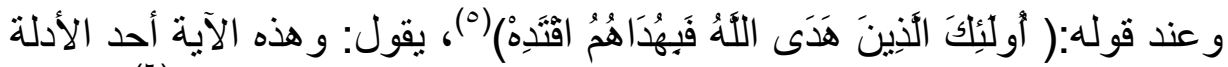

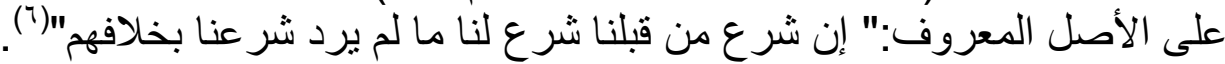

وقد يذكر القاعدة ويدلل عليها فمثلا عند قاعدة:" الوجوب يتعلق بالاستطاعة، فلا

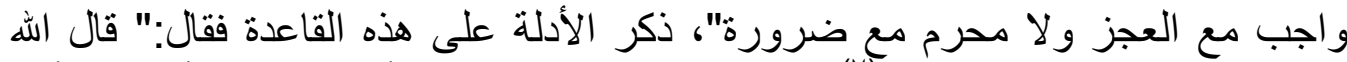

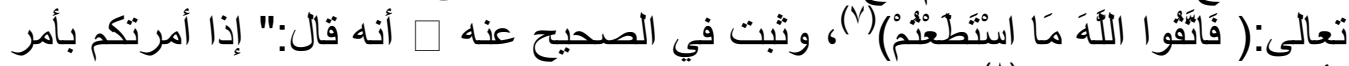

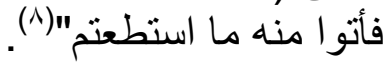
وفي كتاب "القواعد الحسان لتفسير القرآن" ذكر مجموعة من القواعد الأصولية

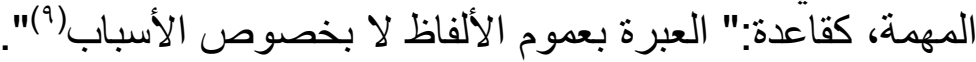

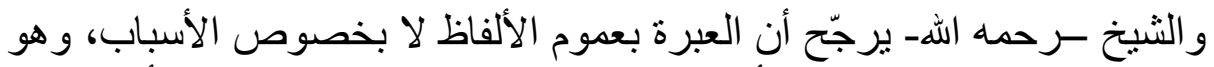

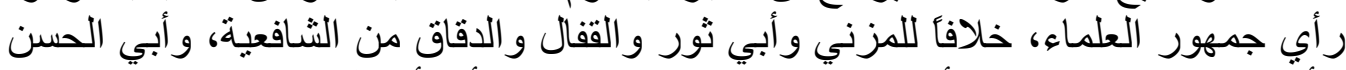

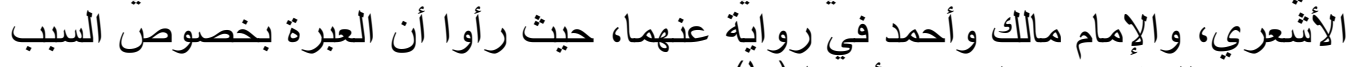

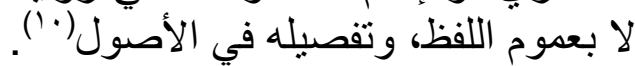

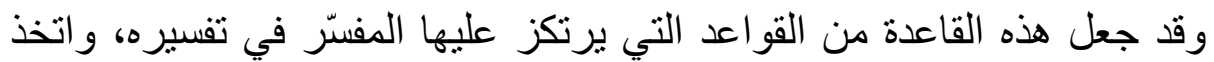
منها منهجأ يسير عليه في الأوامر والنواهي؛ حيث يقول:" وهذا الأصل اتفق علئ لفيه

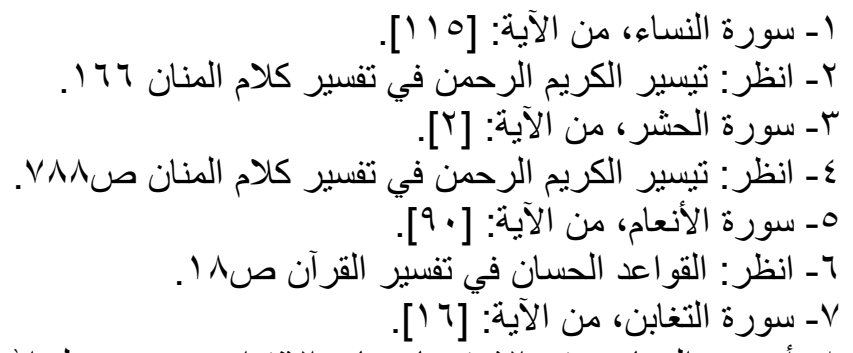

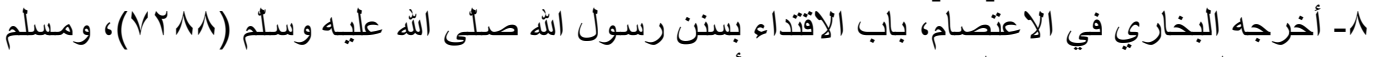

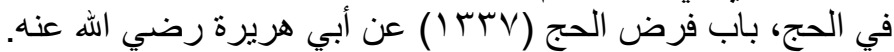

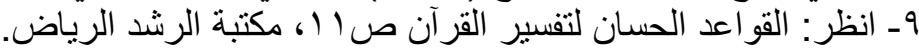

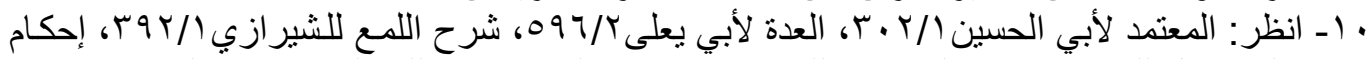

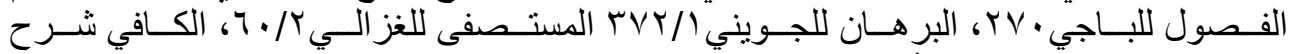

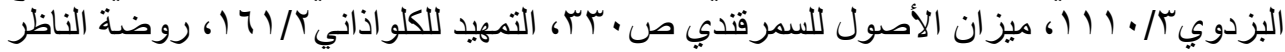

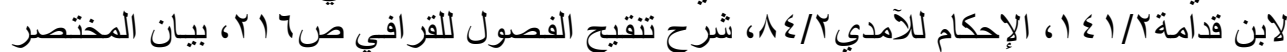

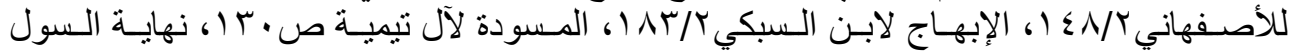

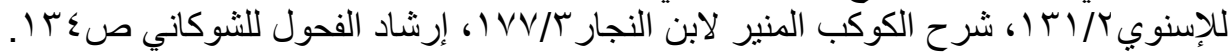




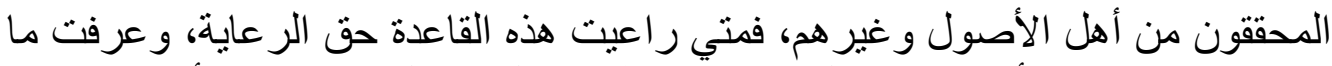

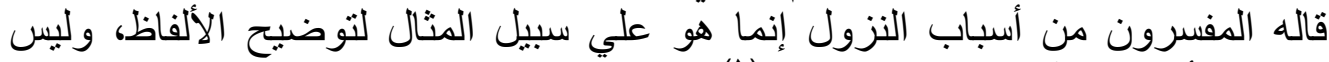

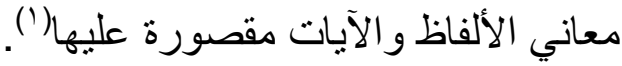

وذكر قاعدة:" الألف واللام إذا الداخلة على الأوصاف وأسورة وأسماء الأجناس تفبد الاستغراق بحسب ما دخلت عليه"، وقد دلل على هذه القاعدة وذكر مجمو عة من الأمثلة

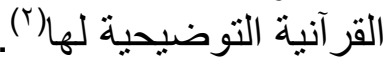

والثيخ السعدي ـرحمه الله- بهذا يوافق جمهور الأصوليين، ويخالف الواقفية

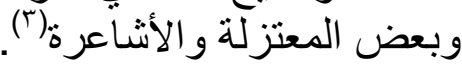

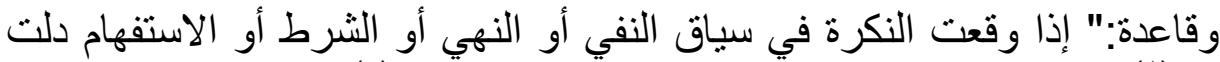

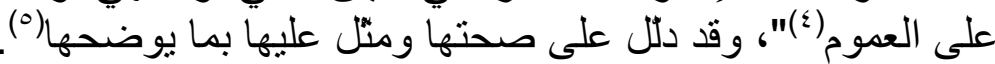

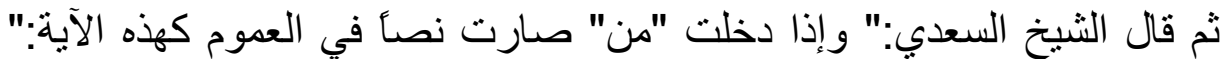

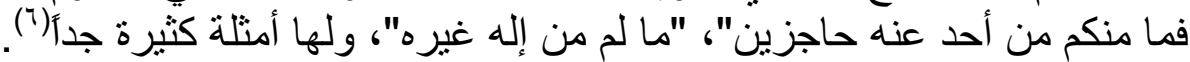

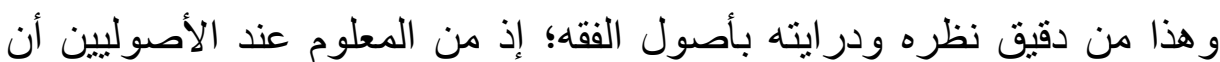

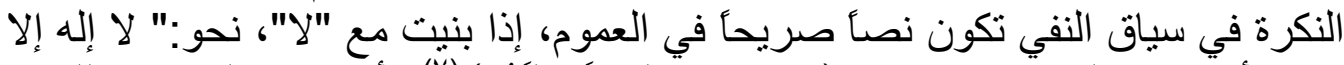

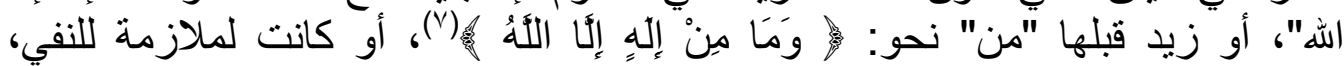

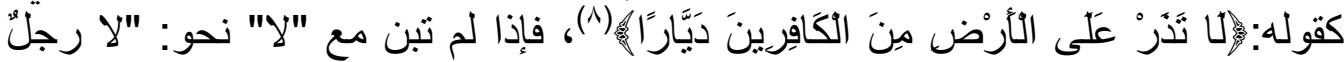

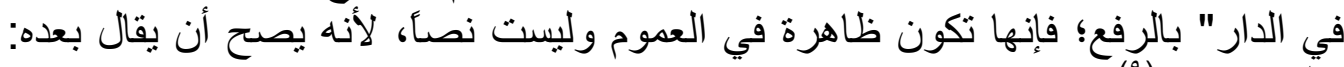

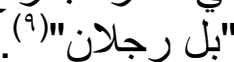

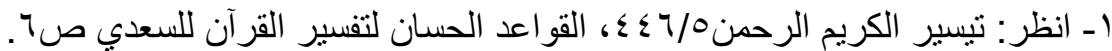

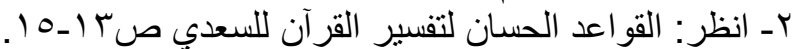

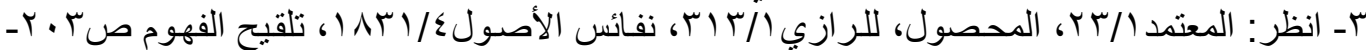

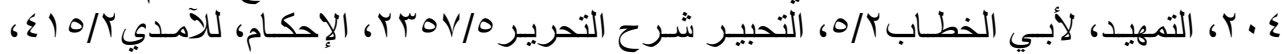

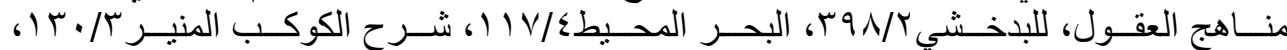

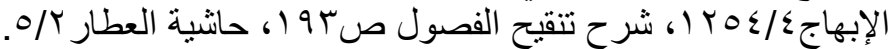

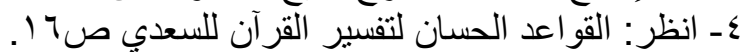

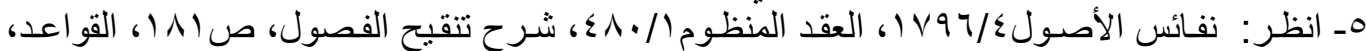

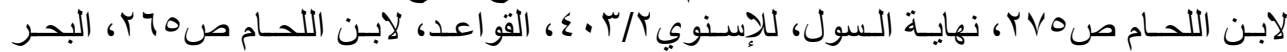

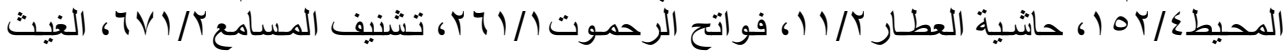

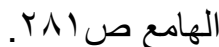

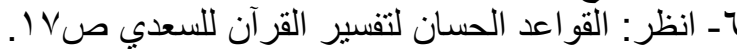

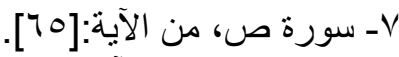

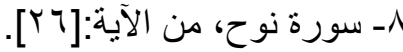

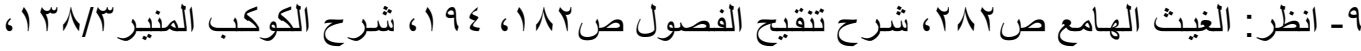




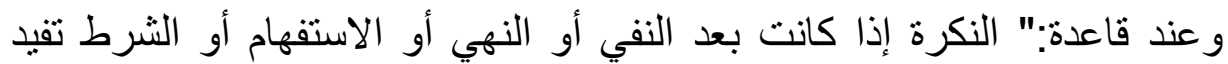

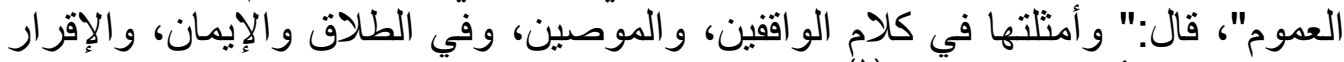

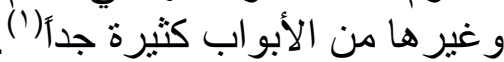

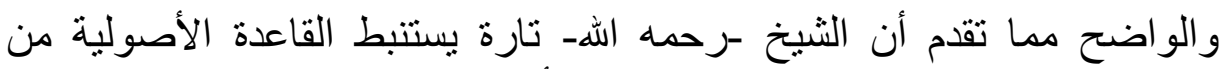

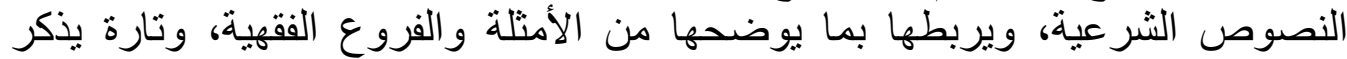

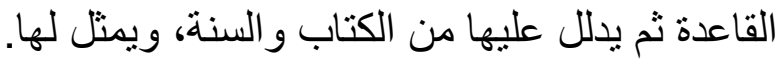

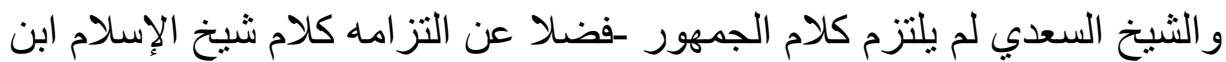

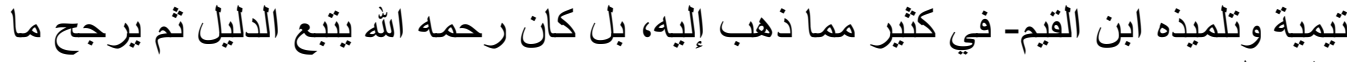

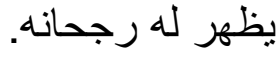

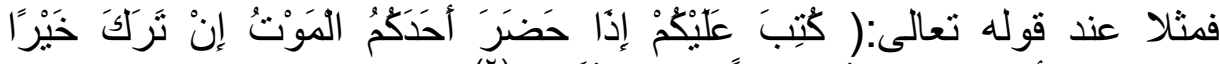

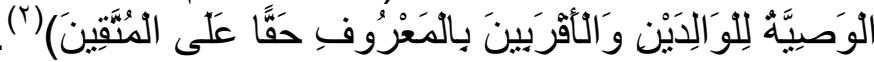

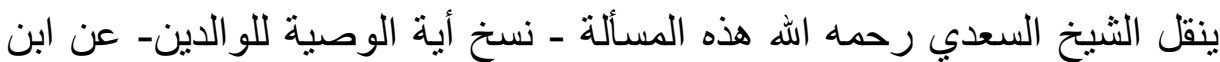

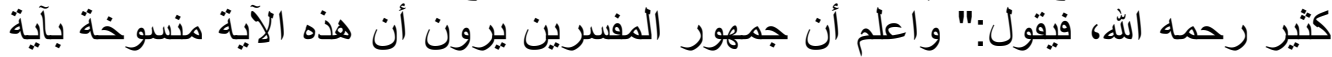

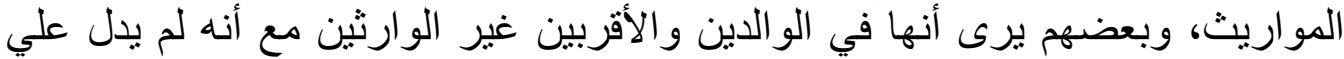

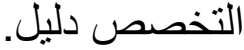

و الأحسن في هذا أن يقول إن هذه الوصية للوالدين والأقربين مجملة ردها الله

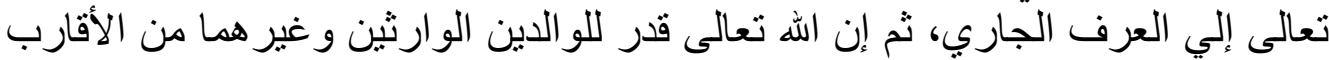

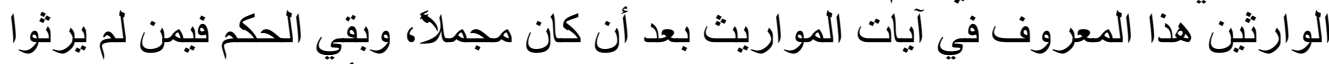

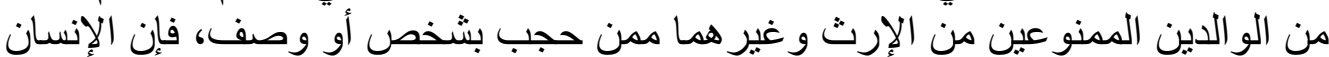

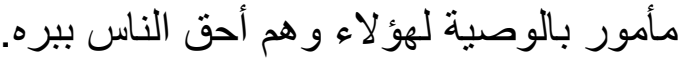

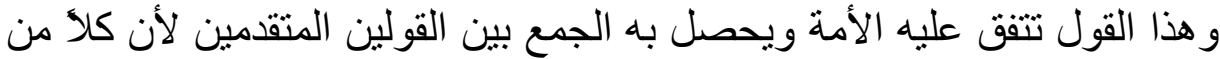
القائلين بها كل منهم لحظ ملحظأ واختلف المورد. فبهذا الجمع يحصل الاتفاق والجمع بين الآيات فإنه لو أمكن الجمع كان أحسن

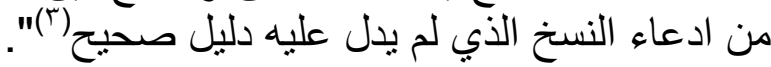

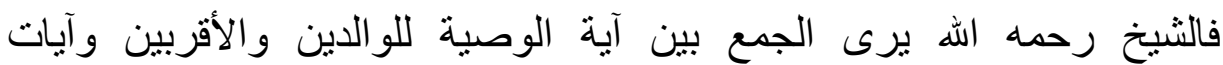
المواريث، وذللك أن آية الوصية للوالدين والأقربين مجملة وآيات المواريث بينة لإينت هذا

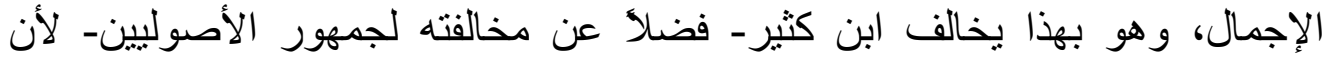

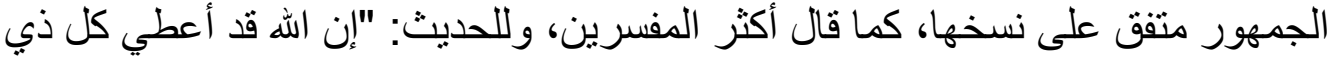
حق حقه فلا وصية لو ارثي فتها،

1ـ انظر: القو اعد والأصول الجامعة صه 11 1، أثر القواعد الأصولية في اختبارات الثيخ السعدي الفقعية

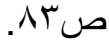

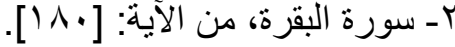

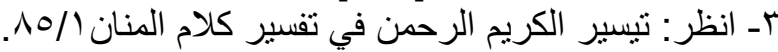




\section{الخاتمة}

\section{وفيها أهم التتائج والتوصيات}

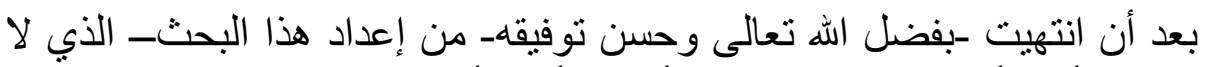
أزعم كماله و لا أنني أتيت بما لم بستطعه الأوائلـ- أذكر أهم النتائج و التوصيات:

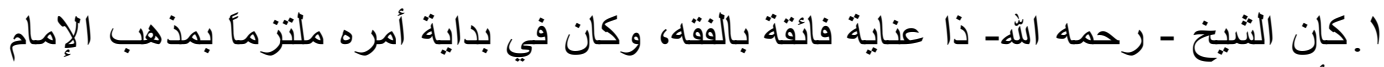

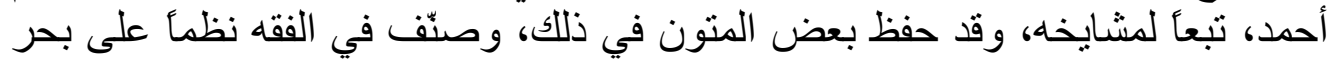

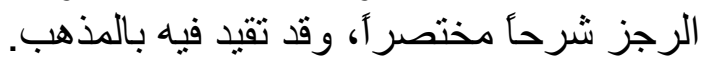

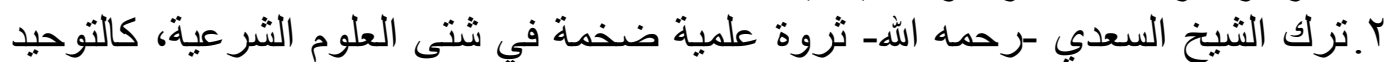

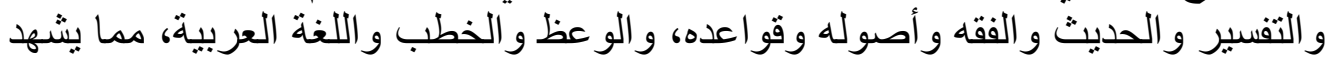

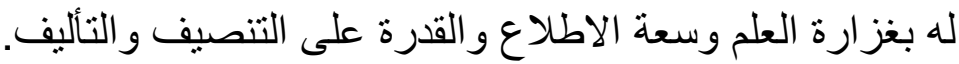

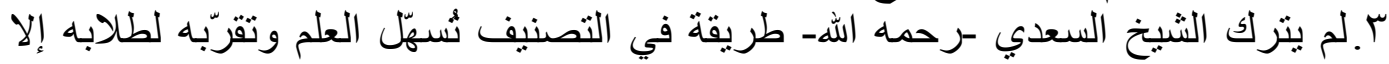

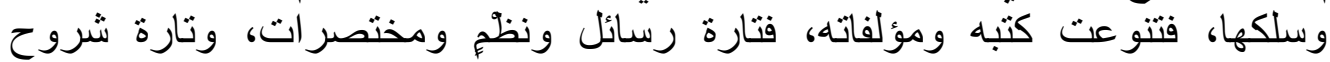
ومطولات، وتارة تأتي مصنفاته على طنى طريقة السؤال وال والجواب، وتارة على ونى طريقة المناظر ات الفقهية.

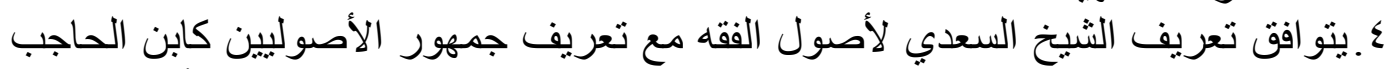

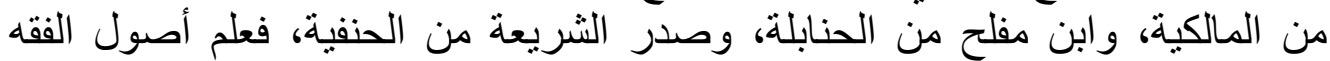

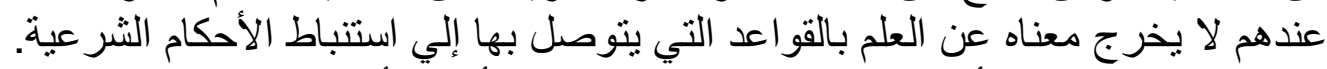

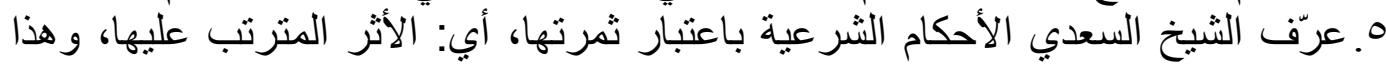

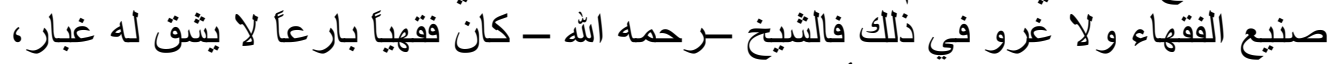

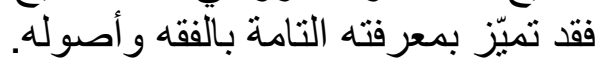

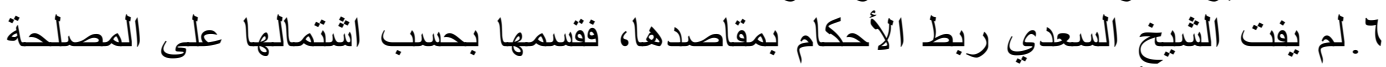

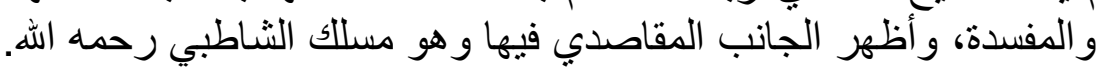

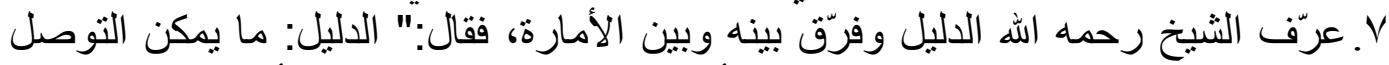

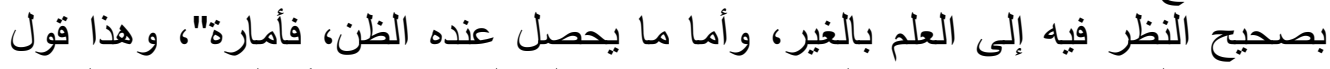

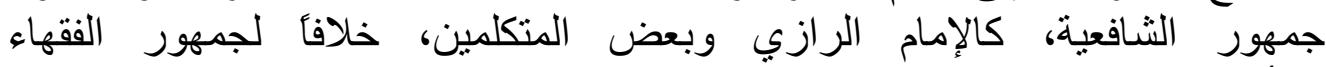
و الأصوليين. ^. . يرى الثيخ -رحمه الله- أن القياس دليل شرعي، لكن لا يعدل إليه إلا عند فقد النص، فهو

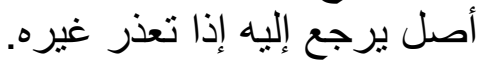

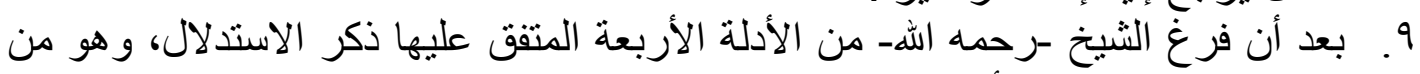
جملة الطرق المفيدة للأحكام.

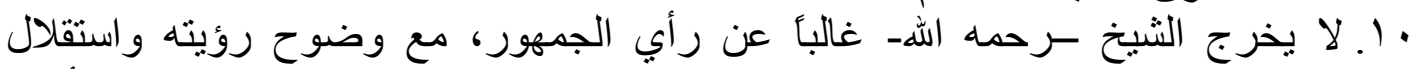

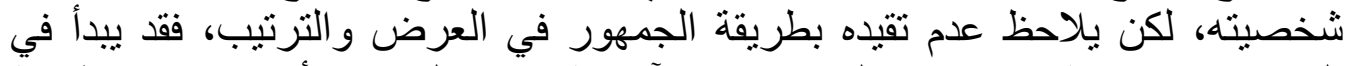

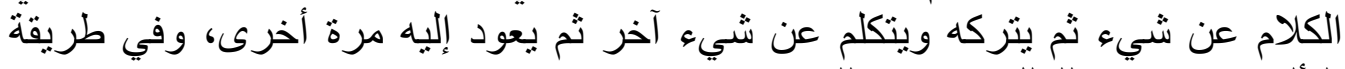
التأليف هذه كسر للملل وتشويق للقارئ. 


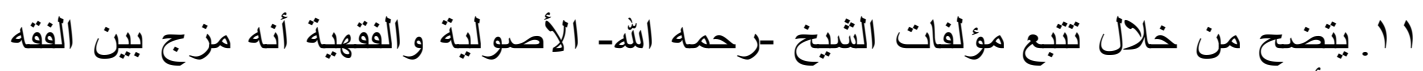

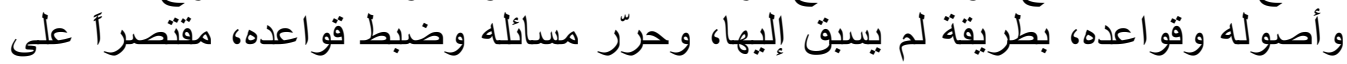

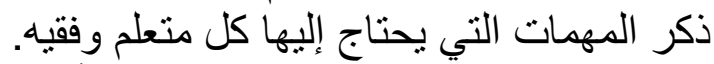

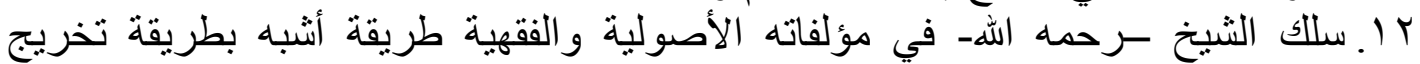

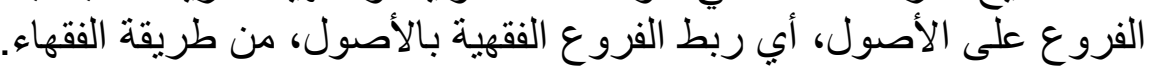

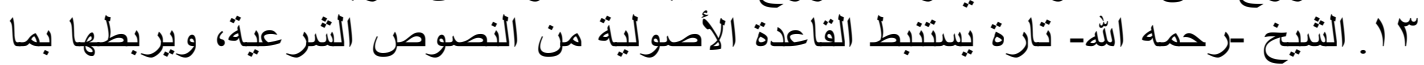

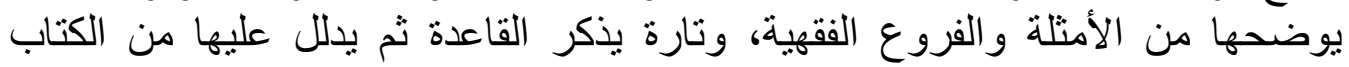

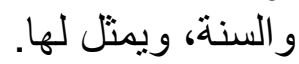
ع ا التركيز والاهنمام بمثل هؤلاء العلماء الأفاضل الذين أفنوا أعمارهم في خدمة الدين

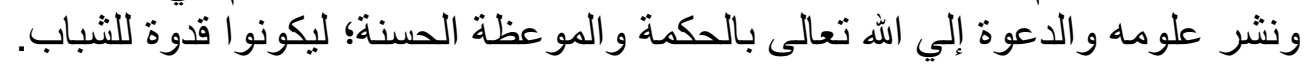

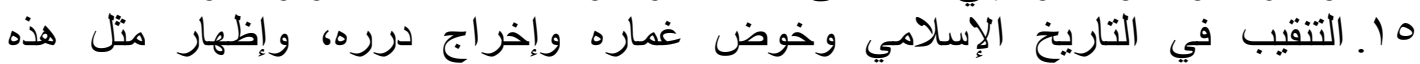

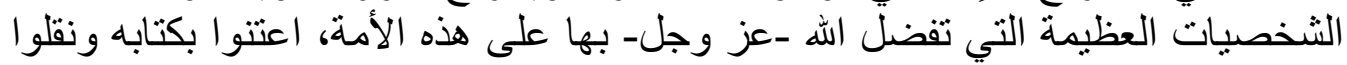
سنة رسوله وميّزوا صحيحها من سقيمها، وصنّفوا حولهما المصنفات في شتى العلى العهوم و الفنون. 


\section{المراجع والمصادر}

ا. الإبهاج في شرح المنهاج، من أوله حتى قول المصنف "الواجب إن تناول كل واحد..

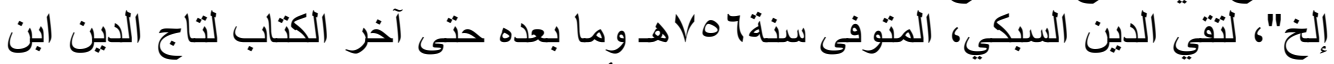

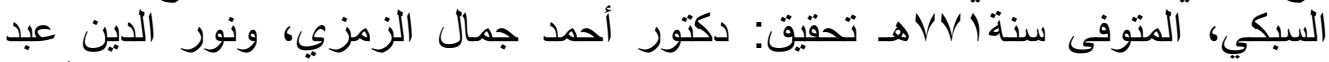

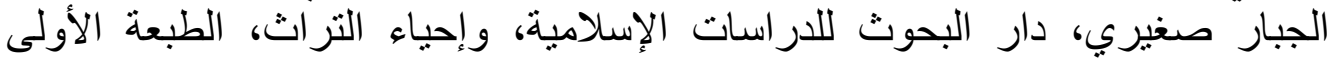

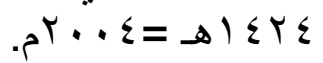

r. أثز القواعد الأصولية في اختيارات الثيخ عبد الرحمن السعدي الفقهية للمسائل النازلة

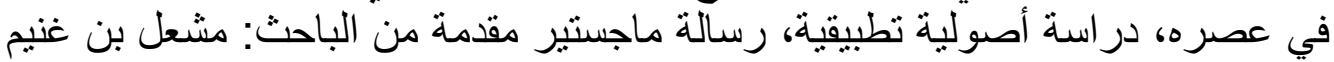

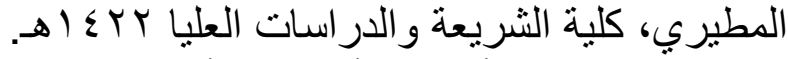

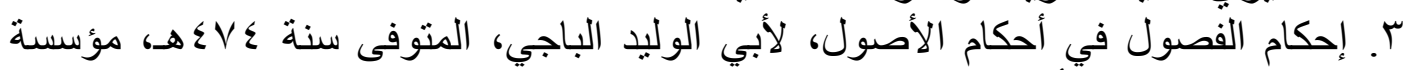

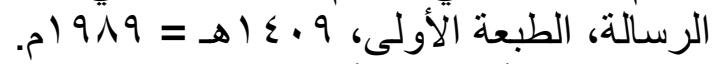

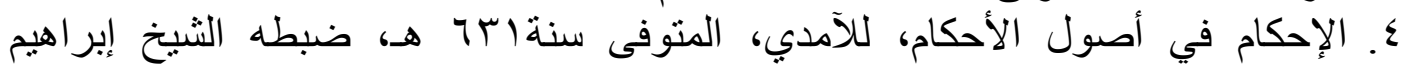

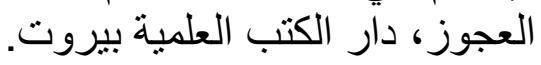

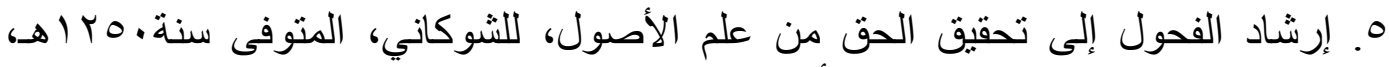

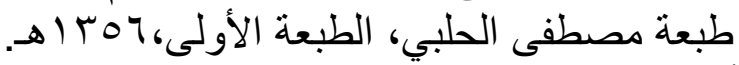

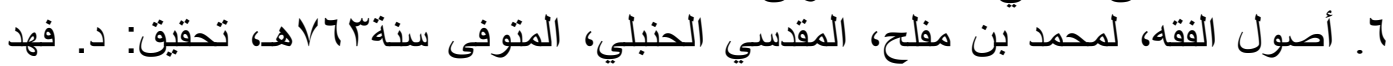

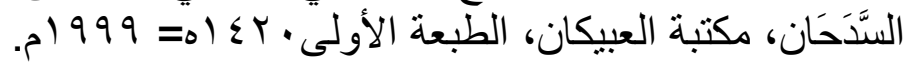

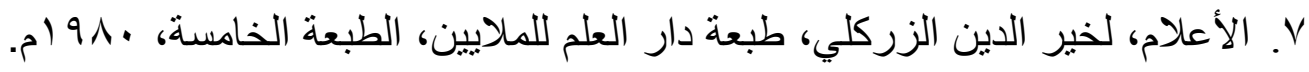

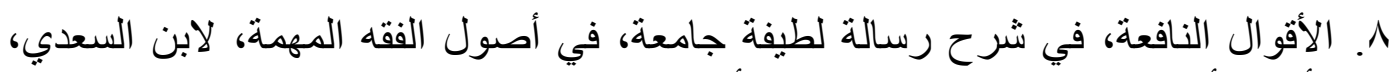

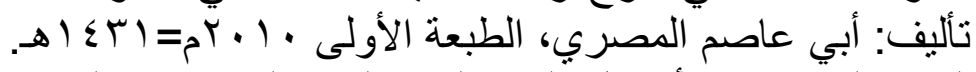

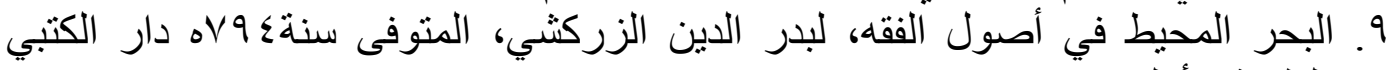

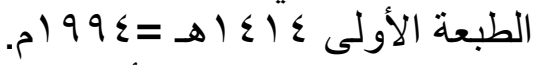

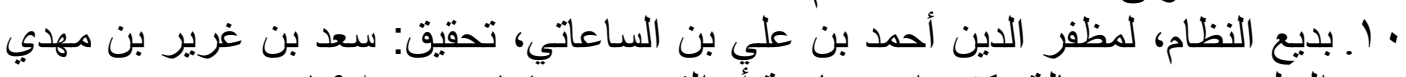

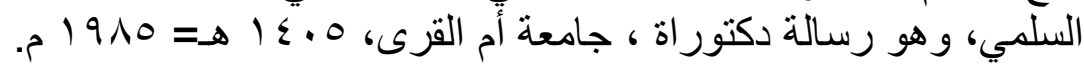

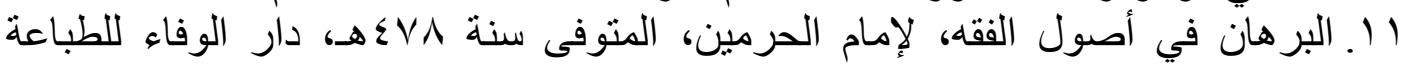

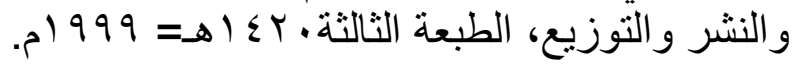

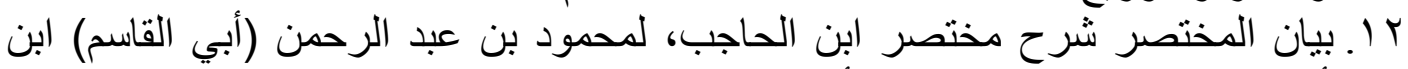

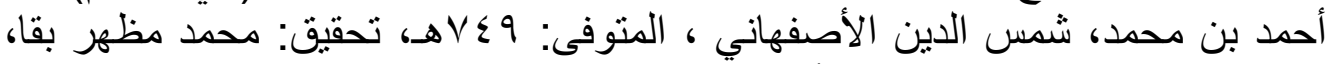

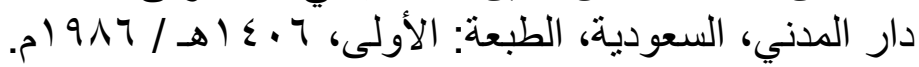

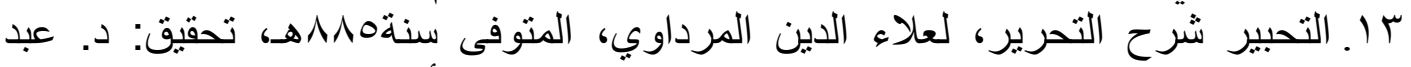

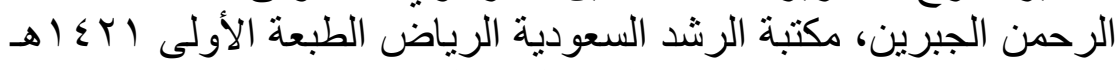

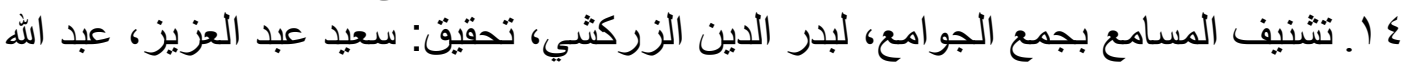

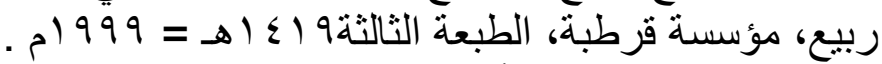

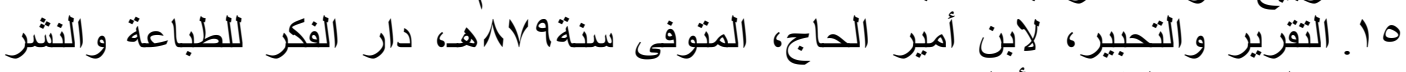

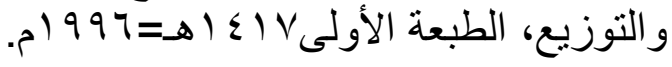




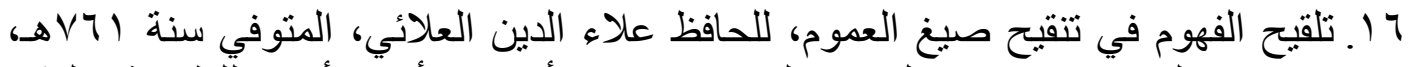

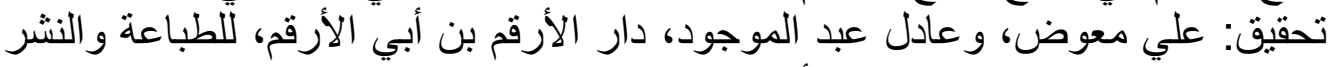

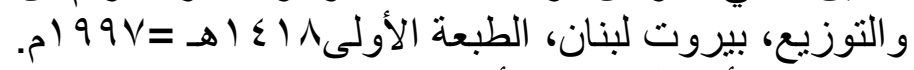

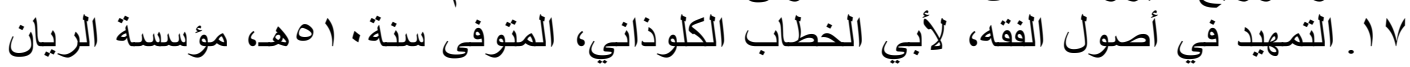

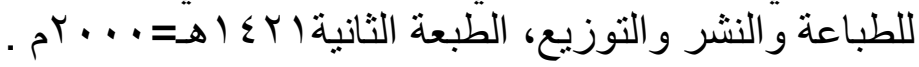

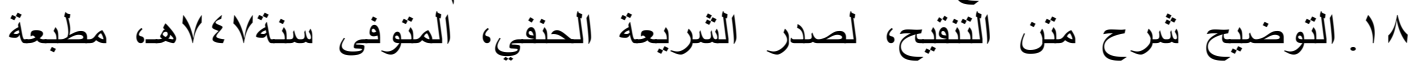
مصطفى الحلبي. 9 1. تيسير التحرير، لمحمد أمين، المعروف بـ "بأمير باد شاه"، دار الفكر للطباعة والنشر

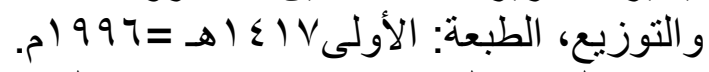

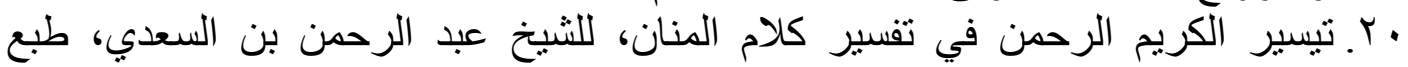

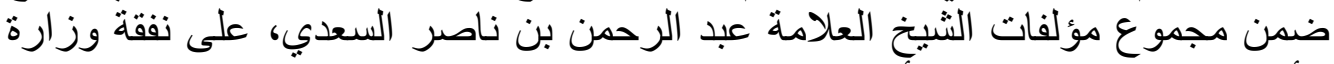

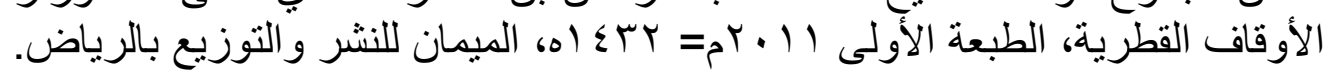

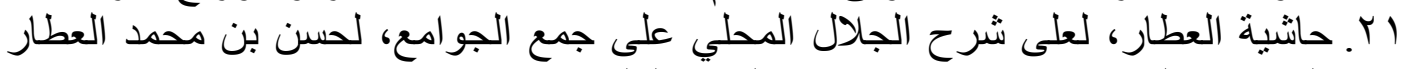

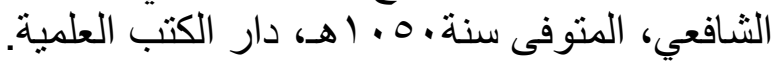

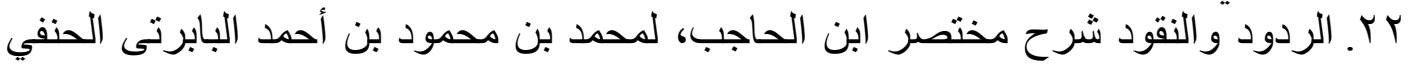

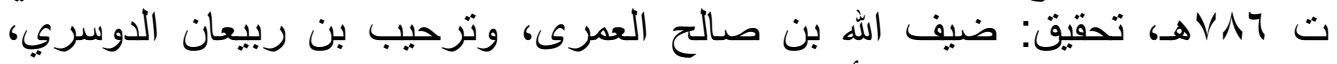

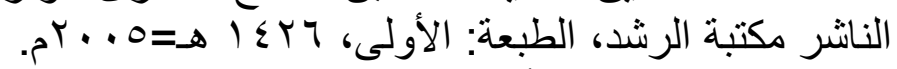

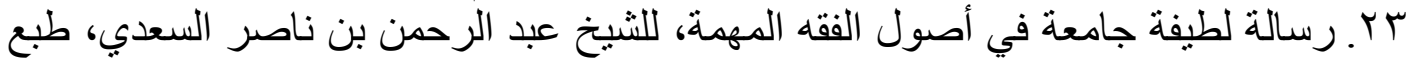

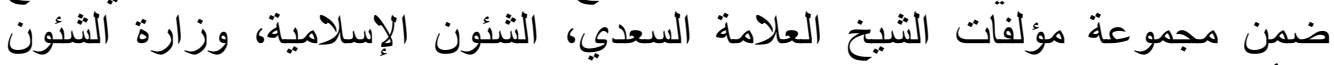

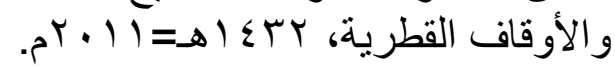
وطبع بشرح د/ ناصر بن سعد بن عبد العزيز الثشري، دارئ دار كنوز إثبيليا للنشر

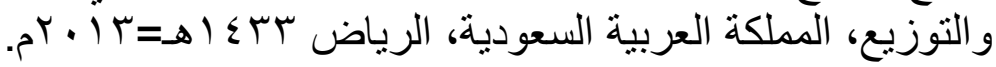

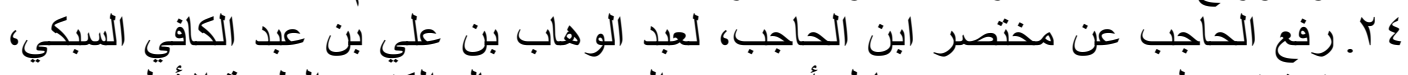

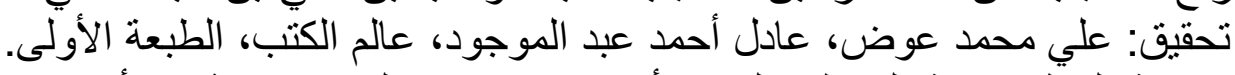

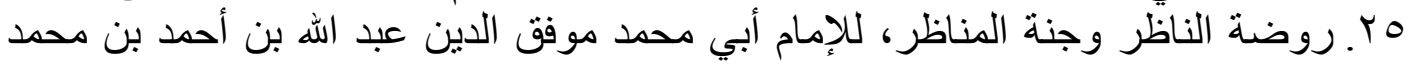

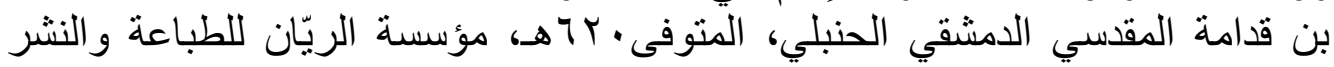

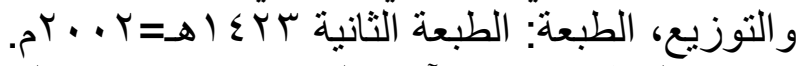

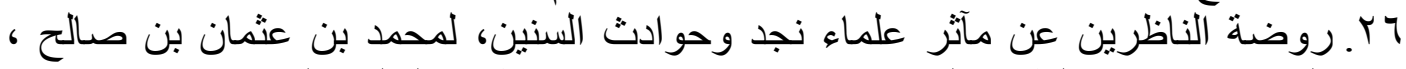

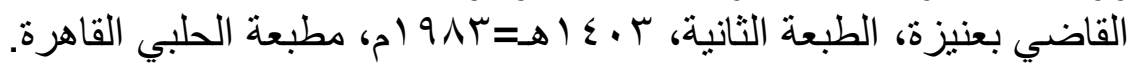

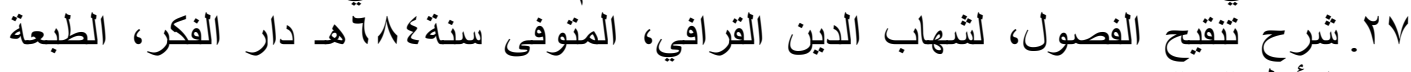

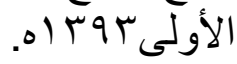
^ץ. شرح الكوكب المنير، لمحمد بن أحمد بن عبد العزيز الفتوحي، المعروف بابن النجان النجار

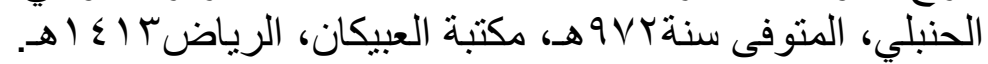

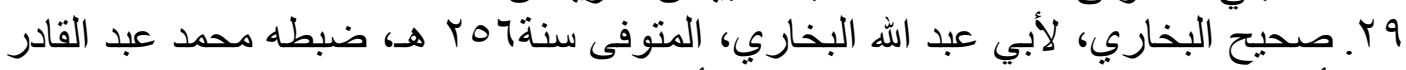

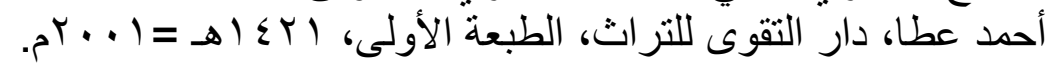

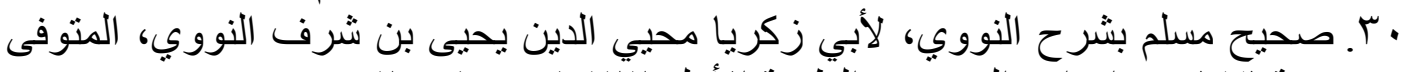

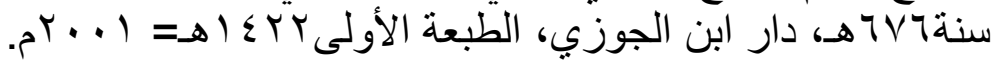




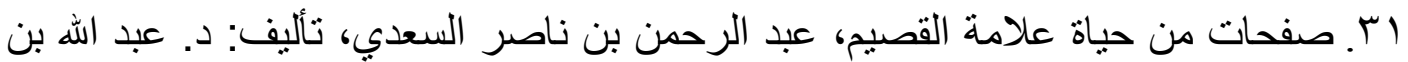

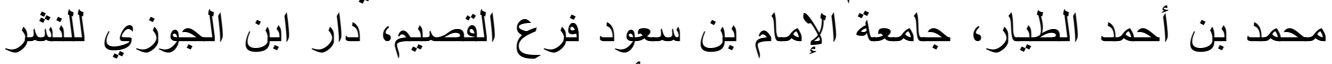

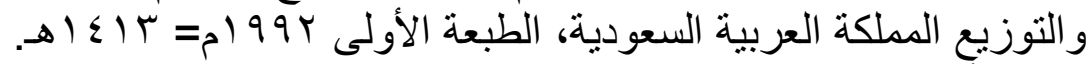

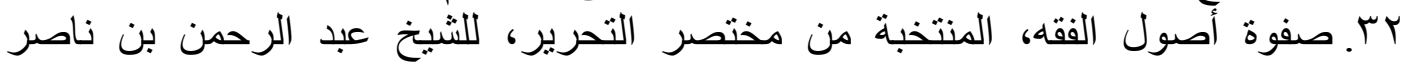
السعدي، اعتنى بها: عبد اللاه بن عثمان الثايع، دار العصيمي للنشر والتوزيع، الطبعة التهن

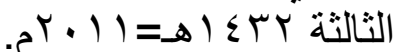

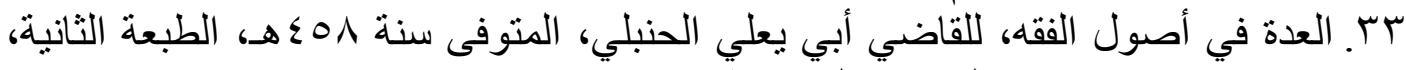

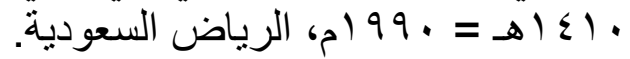

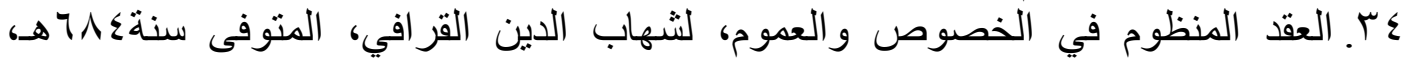

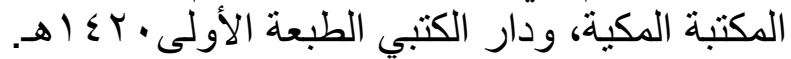

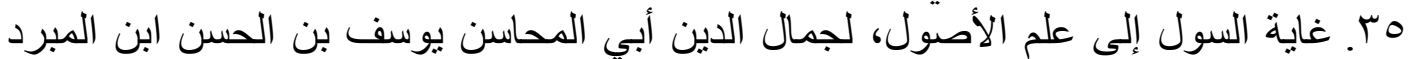

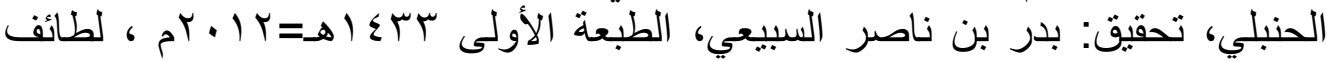
لنشر الكتب و الرسائل العلمية، الكويت.

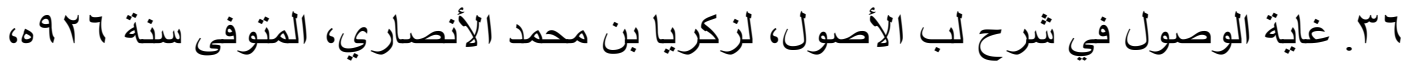

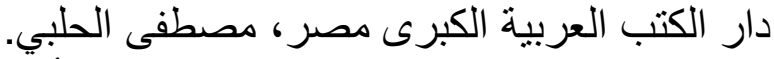

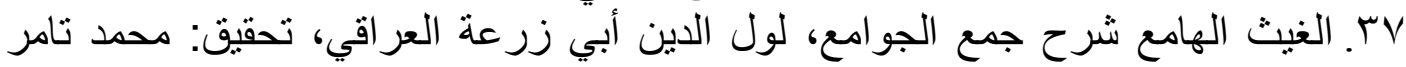

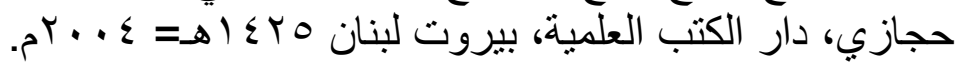

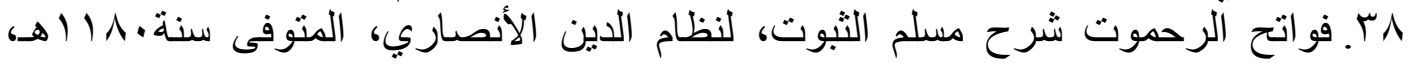

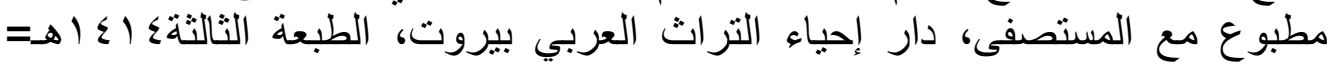

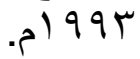

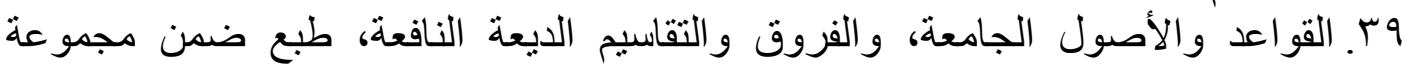

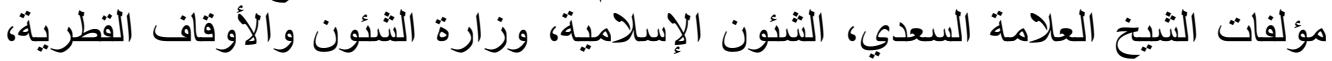

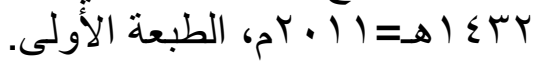

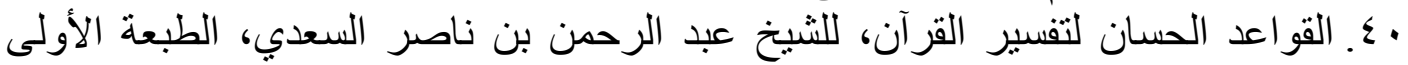

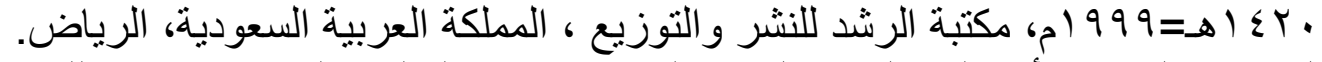

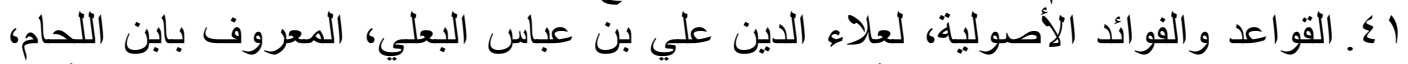

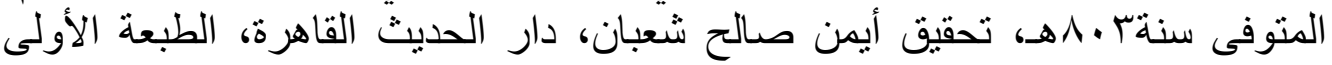

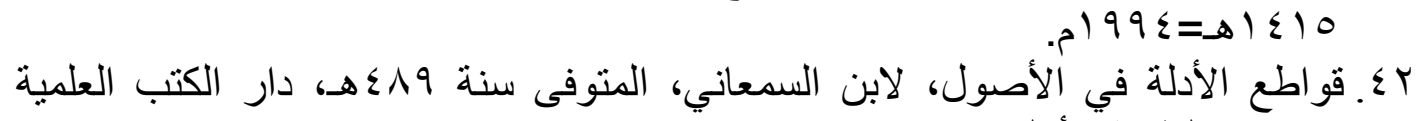

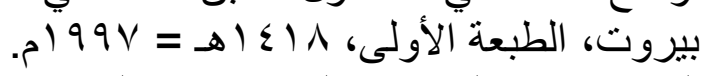

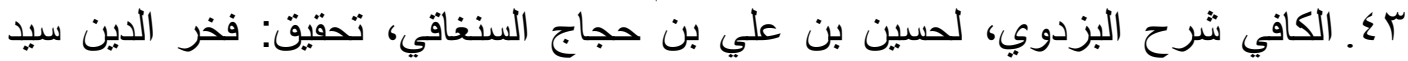

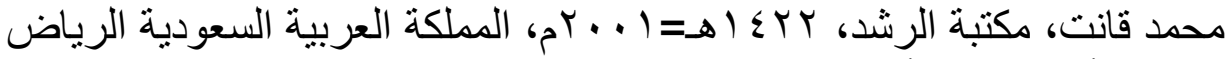

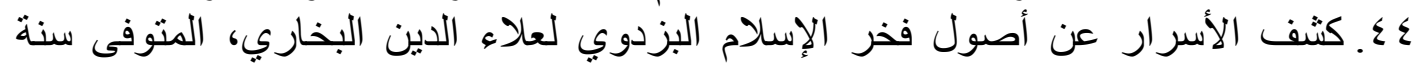

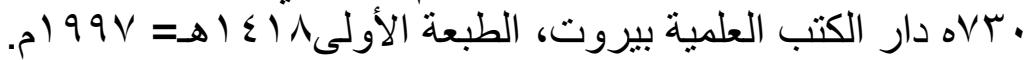

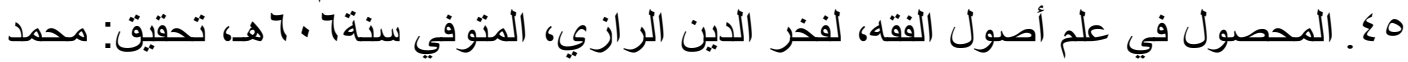

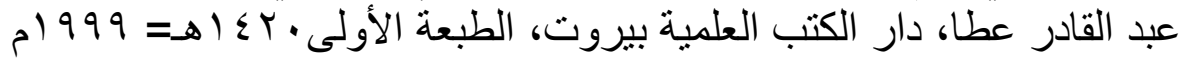




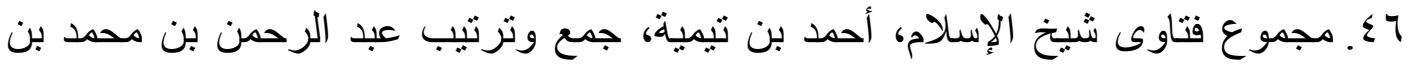

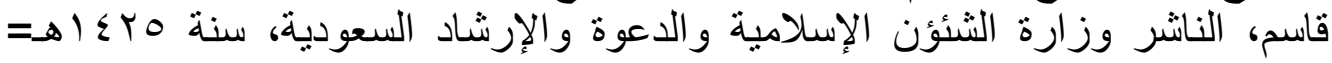

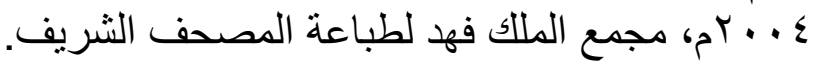

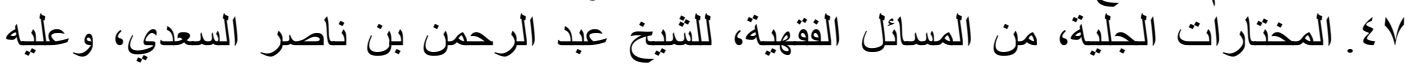

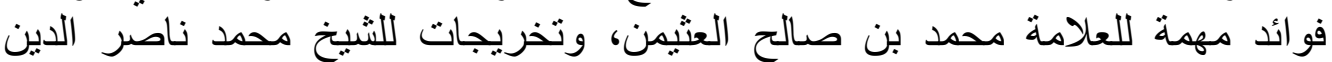
الألباني، اعتني به أبو عبد الرحمن محمد بن عيادي خاطر، الطن الطبعة الأولى، دار الآثار للنشر و التوزيع، القاهرة.

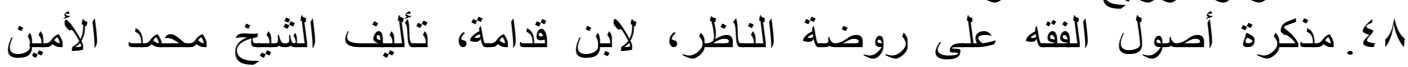

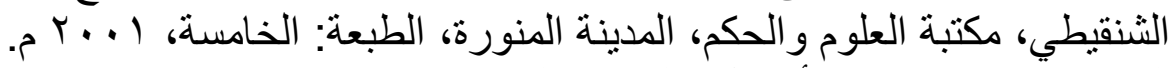

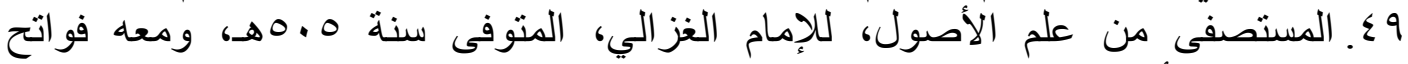

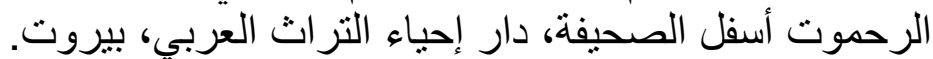

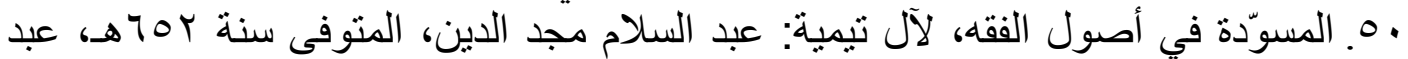

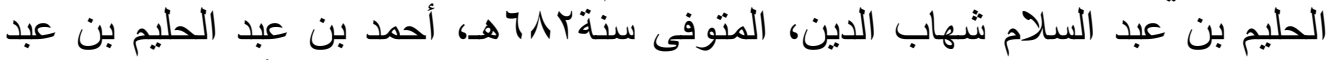

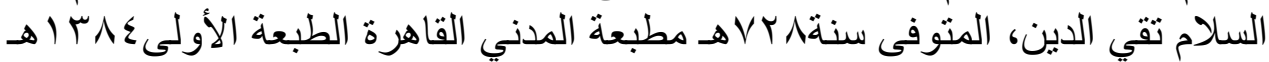

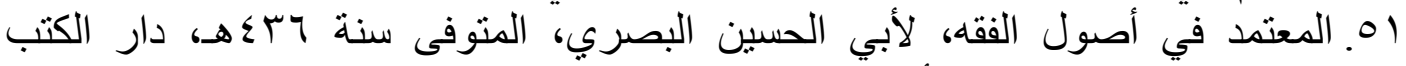

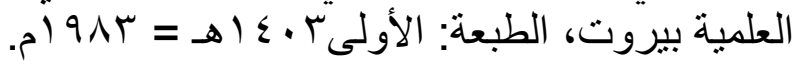

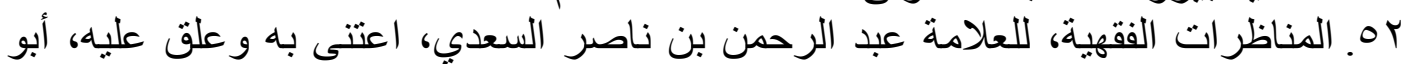

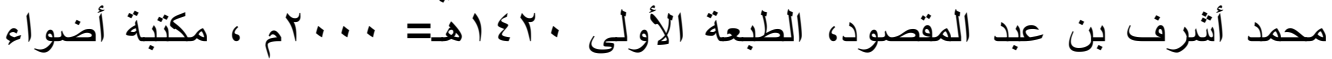
السلف، المملكة العربية السعودية الرياض.

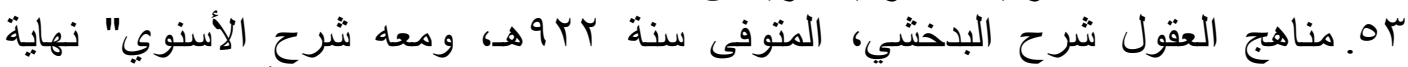

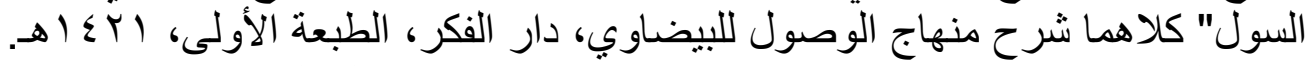

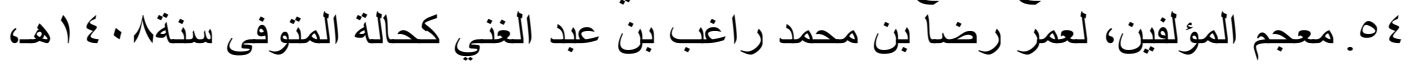

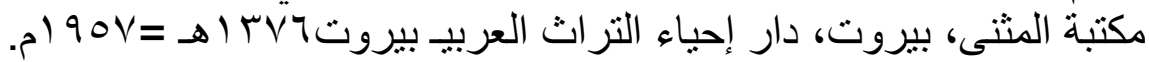

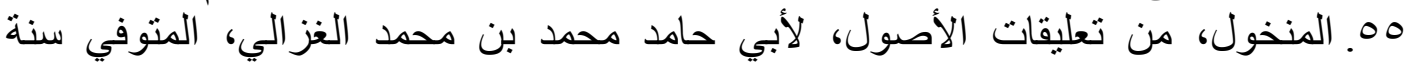

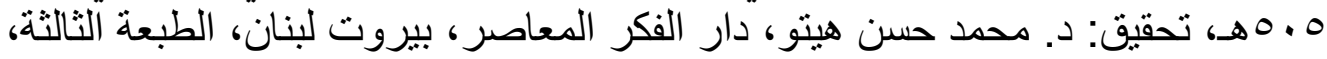

$$
\text { (991 =ـ1 } 919
$$



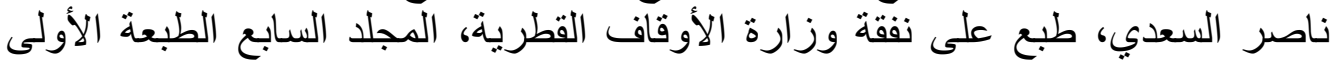

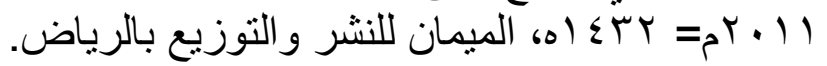

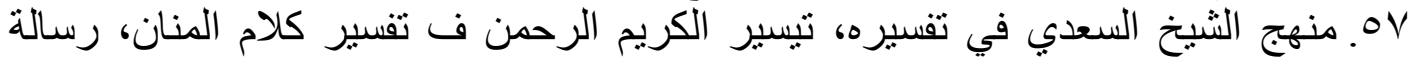

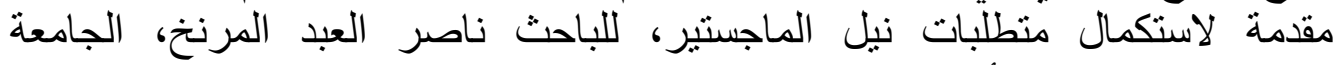

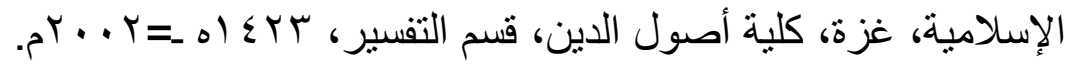

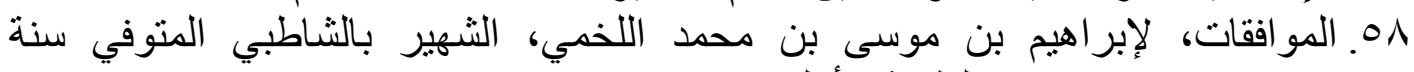

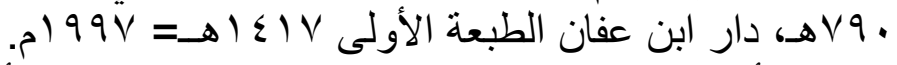

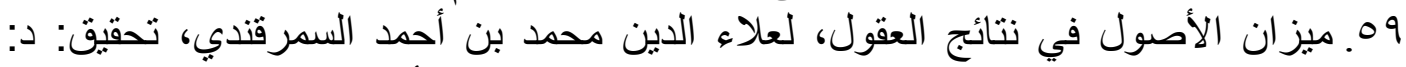

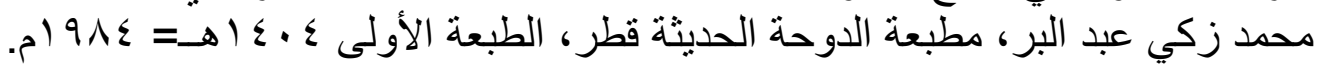


• 7. نشر البنود عن مراقي السعود، لعبد الله بن إبراهيم العلوي الثنقطي، الناشر مطبعة فضالة بالمغرب، بذون تاريخ.

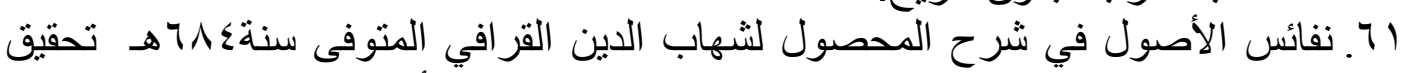

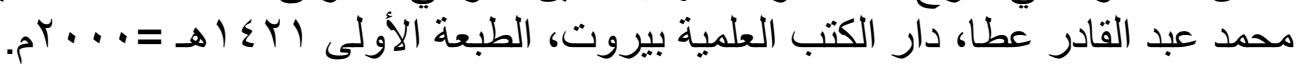

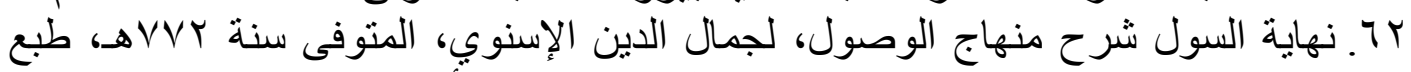

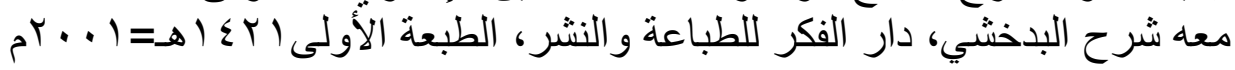

